\title{
USO DO MODELO CERES-MAIZE PARA PREVISÃO DE SAFRA DO MILHO "SAFRINHA"
}

\section{CECILIA MANUELA TOJO SOLER}

Tese apresentada à Escola Superior de Agricultura "Luiz de Queiroz", Universidade de São Paulo, para obtenção do título de Doutor em Agronomia, Área de Concentração: Irrigação e Drenagem.

P I R A C I C A B A

Estado de São Paulo - Brasil

Junho - 2004 


\title{
USO DO MODELO CERES-MAIZE PARA PREVISÃO DE SAFRA DO MILHO “SAFRINHA"
}

\section{CECILIA MANUELA TOJO SOLER}

\author{
Engenheiro Agrônoma
}

Orientador: Prof. Dr. PAULO CESAR SENTELHAS

\begin{abstract}
Tese apresentada à Escola Superior de Agricultura "Luiz de Queiroz", Universidade de São Paulo, para obtenção do título de Doutor em Agronomia, Área de Concentração: Irrigação e Drenagem.
\end{abstract}

P I R A C I C A B A

Estado de São Paulo - Brasil

Junho - 2004 
Dados Internacionais de Catalogação na Publicação (CIP)
DIVISÃO DE BIBLIOTECA E DOCUMENTAÇÃO - ESALQ/USP

Tojo Soler, Cecília Manuela

Uso do modelo Ceres-Maize para previsão de safra do milho "safrinha".

$132 \mathrm{p}$.

Tese (doutorado) - - Escola Superior de Agricultura Luiz de Queiroz, 2004. Bibliografia.

1. Fenologia 2. Milho 3. Safra 4. Semeadura I. Título

CDD 633.15

"Permitida a cópia total ou parcial deste documento, desde que citada a fonte - O autor" 
Aos meus amados pais

Aída Soler e Rubén Tojo, OFEREÇO

À Axel Garcia y Garcia e Rodrigo F. Tojo Garcia minha amada família, pelo constante apoio e pelo enorme esforço realizado 


\section{AGRADECIMENTOS}

Ao Departamento de Engenharia Rural da ESALQ/USP e a FAPESP (Fundação de Amparo à Pesquisa do Estado de São Paulo) pela oportunidade de aperfeiçoamento, pela concessão de bolsa de estudos e pelos ensinamentos recebidos.

Ao Prof. Dr. Paulo Cesar Sentelhas pela orientação do presente trabalho, pelos excelentes ensinamentos proferidos, pelo seu profissionalismo, pelo incentivo, pela valiosa e permanente colaboração prestada e pela sua amizade.

Ao Professor Dr. Gerrit Hoogenboom, da Universidade da Georgia, Estados Unidos, pela valiosa colaboração prestada, pelos imprescindíveis ensinamentos proferidos, pela infra-estrutura oferecida, pela concessão de bolsa de estudos e pela sua amizade.

Ao Departamento de Produção Vegetal (ESALQ/USP), especialmente ao Professor Dr. Durval Dourado Neto, ao Dr. Edson Teramoto e aos funcionários do campo experimental, pela valiosa colaboração na realização da fase experimental.

Ao Instituto Agronômico (IAC) e especialmente aos Drs. Orivaldo Brunini e Aildson Pereira Duarte pelo fornecimento de informações meteorológicas e pelo suporte na condução dos experimentos, respectivamente.

Ao Professor Dr. Marcos Vinícius Folegatti pela sua visão do curso de Irrigação e Drenagem, pelo seu apoio e amizade.

Aos amigos Drs. Roberto Terumi Atarassi, Juan Sinforiano Delgado Rojas e Alexandre Heinemann pela permanente colaboração. Aos colegas do curso de Irrigação e Drenagem, pelo constante apoio e amizade nestes maravilhosos anos de estudo.

Aos colegas do "Biological and Agricultural Engeneering Deparment", Campus de Griffin, Universidade da Georgia, Estados Unidos, pelo apoio, colaboração e amizade. 
A seção de Biblioteca da ESALQ-USP, pela eficiência no trabalho e pela colaboração prestada.

Ao Brasil e à sociedade brasileira em geral por terem me oferecido uma excelente possibilidade de aperfeiçoamento. 


\section{SUMÁRIO}

RESUMO......................................................... X

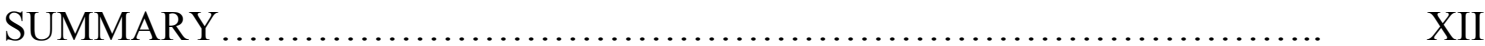

1 INTRODUÇÃ̃O.................................................... 1

2 REVISÃO DE LITERATURA........................................ 4

2. 1 A cultura de milho "safrinha.......................................... 4

2. 2 Modelagem na agricultura....................................... 5

2. 3 Sistema de Suporte à Decisão e Transferência de Agrotecnologia................ 6

2. 4 Generalidades dos modelos Ceres.................................... 8

2. 5 O modelo CERES-Maize.............................................. 8

2. 6 Aplicações dos modelos CERES.............................................. 11

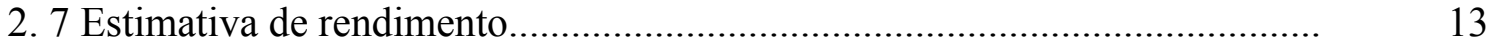

3 ÍNDICES BIOMETEOROLÓGICOS PARA A CARACTERIZAÇÃO DO DESENVOLVIMENTO FENOLÓGICO DE QUATRO HÍBRIDOS DE MILHO SEMEADOS NA "SAFRINHA", NO ESTADO DE SÃO PAULO .................................................................................. 16

RESUMO..................................................... 16

SUMMARY ...................................................... 17

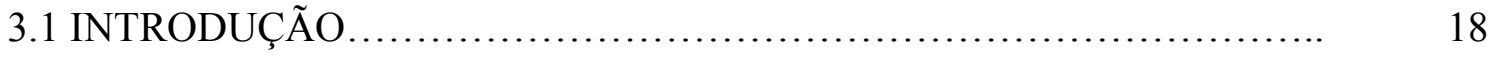

3.2 MATERIAIS E MÉTODOS......................................... 21

3.2.1 Experimentos de campo......................................... 21

3.2.2 Avaliações biométricas......................................... 22

3.2.3 Cálculo dos indices biometeorológicos............................. 24

3.2.4 Análise estatística................................................ $\quad 25$ 
3.2.5 Avaliação dos índices biometeorológicos................................ 26

3.3 RESULTADOS E DISCUSSÃO......................................... 26

3.3.1 Número de folhas................................................. 26

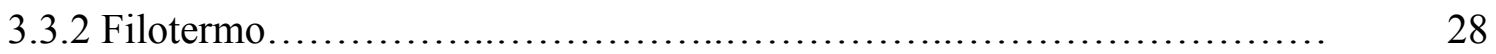

3.3.3 Funções de resposta à temperatura do ar para o sub-período semeaduraflorescimento feminino....................................................................... $\quad 32$

3.3.4 Funções de resposta à temperatura do ar para o sub- período florescimento feminino-maturidade fisiológica..................................... 33

3.3.5 Comparação dos índices biometeorológicos para o sub- período semeadura-florescimento feminino.................................................. $\quad 36$

3.3.6 Comparação dos índices biometeorológicos para o sub-período florescimento feminino-maturidade fisiológica....................................... 41

3.3.7 Avaliação dos indices biometeorológicos com dados independentes........... 43

3.4 CONCLUSÕES .................................................. 46

4 ANÁLISE DE CRESCIMENTO DO MILHO (ZEA MAYS L.) "SAFRINHA" CULTIVADO EM CONDIÇÕES DE SEQUEIRO E IRRIGADAS.......................................................... 48

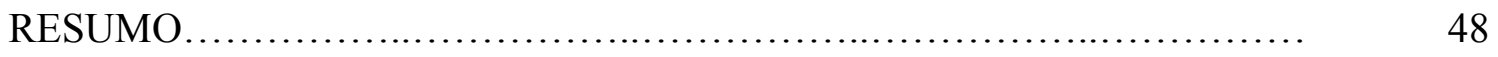

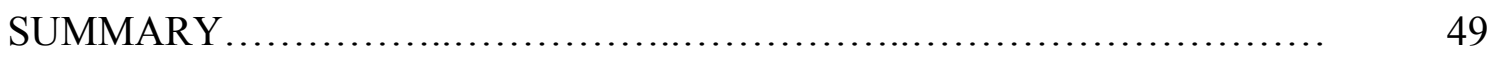

4.1 INTRODUÇÃO......................................................... $\quad 50$

4.2 MATERIAIS E MÉTODOS.............................................. 53

4.2.1 Experimentos de campo............................................ 53

4.2.2 Dados de clima e solo....................................................... 54

4.2.3 Eficiência de uso da água........................................................ 56

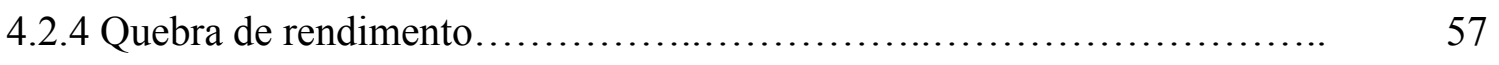

4.2.5 Análise estatística.................................................... 58

4.3 RESULTADOS E DISCUSSÃO.......................................... 58

4.3.1 Condições climáticas e hídricas do solo....................................... 58

4.3.2 Altura das plantas, área foliar e acúmulo de matéria seca............................ 62

4.3.3 Componentes do rendimento....................................... 65 
4.3.4 Rendimento e índice de colheita........................................ 69

4.3.5 Relação entre o rendimento e seus componentes........................ 71

4.3.6 Relação entre evapotranspiração e rendimento......................... 73

4.3.7 Eficiência de uso da água........................................... $\quad 75$

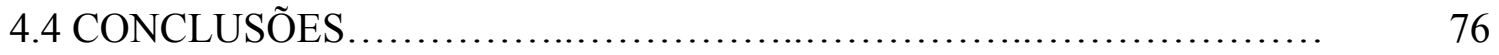

5 AVALIAÇÃO E USO DO MODELO CERES-MAIZE PARA A CULTURA

DO MILHO (ZEA MAYS L.) SEMEADA NA "SAFRINHA", NO ESTADO DE SÃO PAULO ................................................ 78

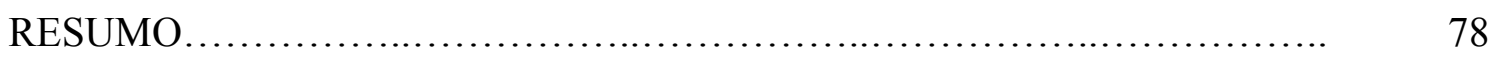

SUMMARY ........................................................ $\quad 79$

5.1 INTRODUÇÃO .................................................... 81

5.2 MATERIAIS E MÉTODOS ........................................ 84

5.2 .1 Experimentos de campo....................................... 84

5.2 .2 Avaliações biométricas......................................... 85

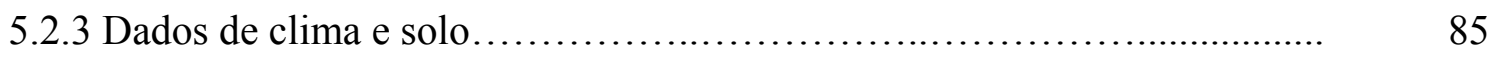

5.2.4 Teste do modelo CERES-Maize.................................... 87

5.2.5 Avaliações de diferentes épocas de semeadura no rendimento do milho "safrinha" ...................................................... 88

5.2.6 Previsão de rendimento do milho "safrinha" ........................... 89

5.2.7 Estudo da influência dos fenômenos El Niño e La Niña no rendimento do milho "safrinha" ........................................................ 89

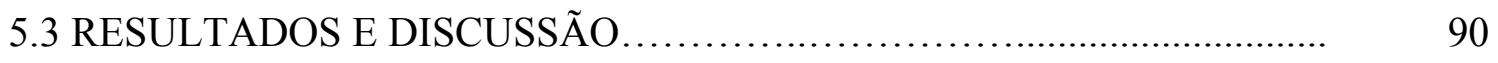

5.3.1 Teste do modelo CERES-Maize............................................... 90

5.3 .2 Conteúdo de água no solo................................................. 100

5.3.3 Uso do modelo CERES-Maize para avaliação de diferentes épocas de semeadura.................................................... 102

5.3.4 Uso do modelo CERES-Maize para a previsão de rendimento................... 107

5.3.5 Relação entre os fenômenos El Niño e La Niña e o rendimento de milho "safrinha"

5.4 CONCLUSÕES..................................................... 111 
6 CONCLUSÕES GERAIS............................................. 113

7 REFERÊNCIAS BIBLIOGRÁFICAS ...................................... 115 


\title{
USO DO MODELO CERES-MAIZE PARA PREVISÃO DE SAFRA DO MILHO “SAFRINHA"
}

\author{
Autora: CECILIA MANUELA TOJO SOLER \\ Orientador: Prof. Dr. PAULO CESAR SENTELHAS
}

\section{RESUMO}

O presente trabalho teve como objetivos: 1) estudar a fenologia, o crescimento e desenvolvimento de quatro híbridos de milho AG9010, DAS CO32, Exceler e DKB 333B semeados no período da "safrinha" na região de Piracicaba, Estado de São Paulo; 2) calibrar e testar o desempenho do modelo CERES-Maize para simular o desenvolvimento e a produtividade do milho "safrinha" para a mencionada região; 3) aplicar o modelo calibrado e testado para a determinação das épocas de semeadura com menores riscos, para as condições de sequeiro e irrigada, para os quatro híbridos mencionados; 4) aplicar o modelo CERES-Maize para simulações de longo período visando a estimativa da previsão de safra do milho "safrinha" na região de Piracicaba, Estado de São Paulo; 5) verificar a existência de associação entre parâmetros climáticos e o fenômeno do ENOS (El Niño Oscilação Sul) na região de Piracicaba, Estado de São Paulo; 6) analisar a influencia do fenômeno do ENOS na produtividade da cultura do milho "safrinha". Para tanto, três experimentos de campo com quatro híbridos de milho foram conduzidos na Escola Superior de Agricultura "Luiz de Queiroz", Universidade de São Paulo, em Piracicaba, Estado de São Paulo, Brasil, durante os anos de 2001 e 2002. Um experimento foi conduzido no ano 2001 sob condições irrigadas e os outros 
dois no ano 2002: um sob condições de sequeiro e outro sob irrigação. Todos os experimentos tiveram delineamento de blocos completos ao acaso. Os híbridos de milho utilizados neste estudo foram: AG9010 (ciclo super precoce), DAS CO32 e Exceler (ciclo precoce) e DKB 333B (ciclo normal). As datas de semeadura foram 15 de março para o experimento de 2001 e 13 de março para os experimentos conduzidos em 2002. Os resultados obtidos neste estudo indicaram que o milho "safrinha", sob condições de sequeiro, apresentou em geral, menores valores de IAF, altura de planta e acúmulo de matéria seca do que sob condições de irrigação. A cultura submetida a limitação de água no solo teve uma atividade radicular intensa nas camadas mais profundas do solo, sugerindo que um incremento no comprimento das raízes foi a resposta às deficiências hídricas. O modelo CERES-Maize simulou com adequada precisão a fenologia e o rendimento do milho "safrinha" para as condições de Piracicaba. Em geral, para os dois sistemas de cultivo, sob irrigação e sob sequeiro, quanto mais tardia a semeadura, menor o rendimento do milho "safrinha" simulado para os quatro híbridos. O modelo CERESMaize mostrou ser uma excelente ferramenta para a previsão do rendimento do milho "safrinha", utilizando-se dados climatológicos combinados aos dados meteorológicos do ano em questão. Com esse procedimento foi possível se obter adequada estimativa do rendimento com 45 dias de antecedência à colheita nos quatro híbridos de milho semeados na "safrinha" em Piracicaba. Os fenômenos "El Niño" e "La Niña" tiveram influência sobre o rendimento do milho "safrinha" em Piracicaba, em decorrência de mudanças nos padrões de precipitação durante os meses de abril e maio. Os rendimentos foram maiores durante os anos de "El Niño" do que em anos de "La Niña", que por sua vez foram superiores aos rendimentos obtidos para os anos neutros. 


\title{
USING CERES-MAIZE MODEL FOR MAIZE SOWN OFF-SEASON YIELD FORECAST
}

\author{
Author: CECILIA MANUELA TOJO SOLER \\ Adviser: Prof. Dr. PAULO CESAR SENTELHAS
}

\section{SUMMARY}

The objectives of the present work were: 1) to study the phenology and development of four maize hybrids: AG9010, DAS CO32, Exceler and DKB 333B sown off-season in Piracicaba region, State of São Paulo, Brazil; 2) to calibrate and test the CERES-Maize model to estimate the productivity and development for the four maize hybrids sown off-season for the mentioned region; 3) to apply the model for determination of sowing dates with less risk, for irrigated and rainfed conditions, for the four maize studied hybrids; 4) to apply the CERES-Maize model for long term climatic conditions aiming yield forecast; 5) to verify the association between climatic parameter and ENSO phases (E1 Niño Southern Oscillation) for Piracicaba region; 6) to analyze the influence of ENSO phases in maize productivity. Three field experiments that included four hybrids with different maturity durations were conducted during the autumn and winter growing seasons of 2001 and 2002 at the Escola Superior de Agricultura "Luiz de Queiroz", University of São Paulo, in Piracicaba, SP, Brazil. One experiment was conducted in 2001 under irrigated conditions, and two experiments were conducted in 2002, one under rainfed and another under irrigated conditions. All experiments had a 
randomized complete block design. The maize hybrids used in this study were: AG9010 (very short season), DAS CO32 and Exceler (short season) and DKB 333B (normal season). The sowing dates were March $15^{\text {th }}$, for the 2001 experiment, and March $13^{\text {th }}$, for the 2002 experiments. CERES-Maize model was calibrated and tested with data obtained in these experiments. The results suggested that maize sown off-season under rainfed conditions, presented in general, lower values of LAI, plant height and less dry matter accumulation than under irrigated conditions. An increase in root water uptake on deep layers of the soil was evident on maize crop under soil water limitations conditions. The CERES-Maize model simulated with accuracy the maize phenology and yield for off-season conditions. In general, for the two cropping systems, irrigated and rainfed, as more delayed the planting date is, less simulate yield for the four hybrids. The CERESMaize was an excellent tool for maize off-season yield forecast using climatic historic data combined with data from the year of study. This procedure permitted to obtain a good estimation of yield 45 days before harvest for the hybrids sown off-season in Piracicaba. The ENSO phases had influence on maize sown off-season yield, as result of the precipitation patterns during April and May months. The highest yields were simulated for "El Niño" years, being higher than yields for "La Niña" years, which were higher than for neutral years. 


\section{INTRODUÇÃO}

Nos últimos anos a cultura de milho tem sido considerada uma das principais alternativas para a ocupação do solo durante o outono-inverno, cujo sistema de cultivo é denominado de milho "safrinha". A área cultivada com milho "safrinha" no Estado de São Paulo aumentou de 284.000 ha em 1992 para 341.000 ha em 2001 (Tsunechiro, 2002).

O clima apresenta-se como a principal causa de risco ao nível de rendimento atingível. Existem vários exemplos de quebras de safras devido à ocorrência de adversidades climáticas, causando prejuízos consideráveis. Em vários anos, tem-se observado significativas quedas nos rendimentos devido a problemas com o clima, principalmente relacionados à ocorrência de secas e de geadas. Baixos rendimentos também podem ser resultado do uso de cultivares não adaptados às condições de crescimento da cultura, já que o material genético disponível usualmente provêm de seleções para o período tradicional de cultivo (setembro a dezembro).

Apesar de diversas pesquisas estarem sendo realizadas com a cultura do milho "safrinha" em grande parte do Brasil nos últimos anos, falta de informação técnica para entender o impacto das condições climáticas no rendimento tem sido relatadas (Oliveira e Fornasieri, 1999). Nesse sentido, os modelos de simulação são uma ferramenta bastante útil, podendo predizer a variabilidade do rendimento devido as condições ambientais (Gungula et al., 2003).

Um dos modelos que tem sido utilizado por numerosos pesquisadores em diferentes partes do mundo é o CERES-Maize, que faz parte do sistema DSSAT4.0, "Decision Support System for Agrotechnology Transfer", pertencente ao projeto IBSNAT, "International Benchmark Sites Network for Agrotechnology Transfer". O 
modelo CERES-Maize, simula o crescimento e desenvolvimento do milho. A produtividade e o desenvolvimento da cultura são calculados pelos balanços de água, de nitrogênio e de carbono. O sistema é eficiente para analisar os efeitos do manejo da cultura, tais como, época de semeadura, uso de irrigação, população de plantas, e adubação nitrogenada, sobre a produtividade. Simulações de longo período utilizando séries históricas de dados meteorológicos permitem avaliar o desempenho das diferentes práticas de manejo em termos probabilísticos.

O modelo CERES-Maize também tem sido utilizado para previsão de rendimento (Duchon, 1986; Thornton et al., 1997). Neste caso, o que é interessante, tanto para um tomador de decisão como para um agricultor, é se conhecer a mudança na distribuição projetada do rendimento ao passo que os dados climáticos da estação de crescimento são incorporados à simulação, em substituição aos dados normais. Quanto mais próximo do final da estação de crescimento, menor o número de dias com clima incerto (dados normais), o que leva à estimativa mais precisa do rendimento, com a variância tendendo a se aproximar de zero (Thornton et al., 1997). É importante salientar que no Brasil a metodologia de predição de rendimento de milho é normalmente conduzida mediante formulários preenchidos pelos agricultores, e tem sido considerada uma metodologia com um certo grau de subjetividade e incerteza (Fontana et al., 2000).

Assim, buscando-se integrar a necessidade de maiores informações a respeito da cultura do milho "safrinha", o presente trabalho teve como objetivos:

1) Estudar a fenologia, o crescimento e desenvolvimento de quatro híbridos de milho (AG9010, DAS CO32, Exceler e DKB 333B) semeados no período da "safrinha" na região de Piracicaba, Estado de São Paulo. Particularmente, analisaram-se a) o filotermo (tempo térmico entre folhas sucessivas) e seu impacto no número final de folhas da cultura do milho semeado na "safrinha"; b) três índices biometeorológicos, baseados na temperatura do ar, para a predição da duração dos sub-períodos semeaduraflorescimento feminino e florescimento feminino-maturidade fisiológica; c) a altura, o índice de área foliar (IAF) e o acúmulo de matéria seca pelas plantas em função do tempo térmico; d) o efeito do estresse de água no desenvolvimento e rendimento do 
milho; e f) a eficiência de uso de água na cultura de milho em condições de irrigação e de sequeiro.

2) Calibrar e testar o desempenho do modelo CERES-Maize para estimar a produtividade e o desenvolvimento do milho "safrinha" na região de Piracicaba, Estado de São Paulo.

3) Aplicar o modelo calibrado e testado para a determinação das épocas de semeadura com menores riscos climáticos, para as condições de sequeiro e irrigada, utilizando-se os quatro híbridos de milho estudados, AG9010, DKB 333B, DAS CO32 e Exceler.

4) Aplicar o modelo calibrado e testado para simulações de longo período visando a estimativa da previsão de safra do milho "safrinha" na região de Piracicaba, Estado de São Paulo.

5) Verificar a existência de associação entre parâmetros climáticos e o fenômeno do ENOS (El Niño Oscilação Sul) na região de Piracicaba, Estado de São Paulo, assim como analisar a influencia do fenômeno ENOS na produtividade da cultura do milho "safrinha" nos quatro híbridos estudados. 


\section{REVISÃO DE LITERATURA}

\section{1 A cultura de milho "safrinha"}

O milho "safrinha" é caracterizado pela semeadura em torno do mês de fevereiro, após a colheita de uma cultura de safra, visando o aproveitamento das chuvas remanescentes, antes do período da seca (Esteves et al., 1994).

O cultivo de milho na época da "safrinha" atinge um menor potencial de produtividade, o ciclo da cultura geralmente é maior, e os riscos aumentam em virtude das menores precipitações e temperaturas mais baixas (Cantarella, 1999). Na região do Vale do Paranapanema, no Estado de São Paulo, os rendimentos médios do milho "safrinha" obtidos entre os anos de 1992 e 2002, foram de $2.230 \mathrm{~kg} \mathrm{ha}^{-1}$, com um coeficiente de variação de $35 \%$. No entanto, na safra normal os rendimentos médios foram maiores $\left(3.650 \mathrm{~kg} \mathrm{ha}^{-1}\right)$ e o coeficiente de variação menor (14\%) (Tsunechiro, 1999; IEA, 2003).

Segundo Landers (1994), a cultura de milho "safrinha" apresenta as seguintes vantagens: a) aproveitamento racional de máquinas, equipamentos e mão de obra; b) maior proteção do solo devido à sua cobertura vegetal em maior período do ano; c) antecipação de receitas, com a obtenção de preços mais compensadores; d) sucessão de culturas dentro do mesmo período agrícola; e) melhoramento das condições bio-físicoquímicas do solo; f) melhor controle de plantas invasoras para a cultura subseqüente e, no decorrer do tempo, diminuição gradativa de infestação na área cultivada. Além disso, o cultivo de apenas uma safra durante o ano agrícola contribui para a elevação dos custos de produção, uma vez que toda infra-estrutura fica ociosa no período de entressafra (Oliveira et al., 1994). 


\section{2 Modelagem na agricultura}

Tradicionalmente, as funções de produção usadas para recomendações agrícolas têm sido baseadas em análises de correlação e regressão. O uso desse tipo de análise tem auxiliado no conhecimento qualitativo das variáveis e suas interações envolvidas nos sistemas das culturas e também contribuído para o progresso da ciência da agricultura. No entanto, a informação qualitativa obtida nesse tipo de análise é específica para determinados ambientes, havendo usualmente poucas considerações a respeito dos processos físicos e físiológicos envolvidos (Jame \& Curtforth, 1996).

A interação entre as plantas e o ambiente envolve uma complexidade de processos físicos, químicos e biológicos. A fim de se obter melhor conhecimento das respostas da cultura ao ambiente, modelos de simulação são utilizados como ferramenta de grande potencial na área de sistemas cultivados, permitindo o estudo e entendimento do conjunto, estimando a performance da cultura em diferentes áreas e situações.

Visando ao adequado entendimento da definição de modelos de simulação, Costa (1997) menciona a necessidade de se fazer a separação de três termos: sistemas, modelos, e simulação. Sistema é uma parte limitada da realidade que contém vários elementos inter-relacionados; modelo é uma representação simplificada de um sistema; simulação é a arte de construir modelos matemáticos e de estudar suas propriedades em relação às do sistema (de Wit, 1982).

Jame \& Cutforth (1996) definem modelo como uma série de equações

matemáticas, as quais descrevem um sistema físico, no caso, sistema solo-plantaatmosfera. O modelo simula uma cultura pela estimativa do crescimento de seus componentes, como folhas, raízes, caules e grãos. Assim, um modelo de simulação de crescimento de cultura não somente estima a biomassa total ou a produção na colheita, mas também, inclui informações quantitativas sobre a maioria dos processos envolvidos no crescimento e desenvolvimento da planta.

Segundo Monteith (1996), os modelos de simulação de cultura podem ser definidos como um conjunto de equações para estimar o crescimento, desenvolvimento e produção de uma cultura a partir de uma série de coeficientes genéticos e variáveis 
ambientais. Os modelos permitem analisar detalhadamente os diversos componentes da produção, possibilitando uma visão integrada de sua participação no sistema. Apesar da complexidade envolvida na construção de modelos, os esforços são compensados em função de sua grande aplicabilidade, que auxilia o agricultor na tomada de decisão, permitindo a organização racional de questões envolvendo distribuição, armazenamento, comercialização do produto agrícola, entre outras (Gedanken, 1998).

Existem três níveis de uso dos modelos de simulação de culturas como ferramenta potencialmente útil na tomada de decisões: em pesquisas, em tecnologia de manejo de cultivos e em políticas de planejamento agrícola (Boote et al., 1996; Hoogenboom, 2000).

Modelos podem ser utilizados para analisar os efeitos de diferentes estratégias, ajudando na determinação da melhor decisão, e apresentam uma série de vantagens para uma análise econômica, em relação aos dados provenientes de experimentação em campo. Entre essas vantagens destacam-se: um grande número de diferentes estratégias podem ser avaliadas rapidamente e com baixo custo; cada estratégia pode ser avaliada em um amplo intervalo de condições incertas, como por exemplo, clima; e, dependendo do modelo de crescimento utilizado, pode-se avaliar complexas estratégias de manejo interagindo com diversas decisões como irrigação, fertilização, datas de semeadura, dentre outras (Booges \& Ritchie, 1988).

Vale ressaltar que, embora os modelos de simulação tenham grande aplicabilidade e custo inferior aquele dos experimentos convencionais, eles não podem ser considerados substitutos dos experimentos, e sim uma técnica que os complementa.

\section{3 Sistema de Suporte à Decisão e Transferência de Agrotecnologia}

Nos últimos anos tem-se gerado vários tipos de modelos de simulação para uso em agricultura com diferentes níveis de complexidade. Pela sua importância, destacamse os modelos do IBSNAT (International Benchmark Sites Network for Agrotechnology Transfer), que foi um projeto internacional com sede na Universidade do Havaí, criado para desenvolver um sistema para suporte à decisão e transferência de tecnologia 
agropecuária (Hunt et al., 2001). Esse sistema denominado DSSAT (Decision Support System for Agrotechnology Transfer) tem sido usado amplamente nos últimos 15 anos por pesquisadores de diferentes países do mundo. Este programa é composto por 16 modelos de culturas com aplicativos para avaliar e usar (ferramentas de análises biofísicas e econômicas) os modelos para diferentes propósitos (Baethgen, 1995; Jones, et al., 2003).

Os modelos de simulação do DSSAT estão baseados no enfoque de sistemas, isto é, tratam de compreender as interações dos componentes do sistema sob estudo. No caso particular dos modelos de simulação de culturas, consiste em: a) simular as interações do genótipo com o ambiente e com o manejo e b) predizer o funcionamento de um sistema de produção em resposta aos fatores que o influenciam, como o clima e práticas de manejo (Uehara \& Tsuji, 1993).

Além da estimativa do rendimento, o conjunto de programas do sistema DSSAT permite avaliar o uso dos recursos naturais e estimar o risco associado com diferentes práticas de manejo. Através de uma interface prática, o sistema possibilita: a) introduzir, organizar e armazenar dados das culturas, de solos e de clima b) recuperar, analisar e apresentar dados, c) calibrar e testar modelos de diferentes culturas e d) testar diferentes práticas de manejo num dado local (Jones, 1993).

Logo que o usuário está seguro de que o modelo simula o crescimento e desenvolvimento de uma cultura numa localidade, análises mais complexas da performance do cultivo podem ser conduzidas para diferentes tipos de solo, cultivares, épocas de semeadura, população de plantas e estratégias de irrigação e adubação, com a finalidade de encontrar práticas que sejam mais favoráveis e que envolvam menor risco (Jones et al., 1996; Jame \& Curtforth, 1996; Mavromatis, et al., 2002).

A mais nova versão do sistema DSSAT, o DSSAT4.0 (Jones et al., 2003; Wilkens et al., 2003), foi desenvolvido para operar sob ambiente Windows, sendo a interface com o usuário amigável. Além disso, foi incorporado o modelo Century, para simulação do balanço de matéria orgânica no solo (Gijsman, et al., 2002), o qual é mais apropriado em situações de agricultura com baixo uso de insumos, onde a decomposição da matéria orgânica do solo representa um aporte importante de nitrogênio às culturas. 


\section{4 Generalidades dos modelos Ceres}

Os modelos CERES do programa DSSAT simulam o crescimento diário de gramíneas incluindo o milho. Esses modelos baseiam-se em quatro tipos de variáveis de entrada: solo, clima, manejo do cultivo e genótipos (Boullon, et al., 1996). Os dados diários de clima requeridos são temperatura máxima e mínima, radiação solar e chuva.

O crescimento é simulado por esses modelos considerando-se os seguintes processos:

- Desenvolvimento fenológico, que é especialmente afetado pelo genótipo, temperatura e fotoperíodo.

- Desenvolvimento morfológico: crescimento de folhas, colmos e raízes.

- Acúmulo e partição de fotoassimilados.

- Balanço da água no solo, que simula evaporação, transpiração, escoamento superficial, percolação e infiltração.

- Transformações do nitrogênio no solo associadas com a mineralizaçãoimobilização, consumo de $\mathrm{N}$ pelo cultivo e perdas do $\mathrm{N}$ associado com o escoamento superficial e a percolação (Jones et al., 1996).

\section{50 modelo CERES-Maize}

Em comparação a modelos anteriores, o modelo CERES-Maize (Jones \& Kiniry, 1986), é um dos mais detalhados para predizer estádios fenológicos e número de folhas. São considerados a sensibilidade ao fotoperíodo e os efeitos da alta temperatura no número final de folhas. Além disso, três componentes do desenvolvimento vegetativo, iniciação de folhas, aparecimento de primórdios foliares e iniciação da floração masculina podem ser testados independentemente (Kiniry, 1991).

Os pontos fortes do modelo constam de rotinas para a simulação dos balanço de água e nitrogênio no solo, e suas bases fisiológicas para as taxas de desenvolvimento e partição de assimilados. A maior inovação deste modelo é o conceito de coeficiente genético, o qual significa que uma característica comum a todas as variedades de milho 
pode variar quantitativamente, explicando as diferentes adaptações (Salvador, 1993). Esses coeficientes são os seguintes (Hoogenboom et al., 1994):

-P1: representa a duração do período vegetativo, soma térmica desde a emergência até o final da etapa juvenil, (temperatura base $8^{\circ} \mathrm{C}$ ).

-P2: representa a sensibilidade ao fotoperíodo, dias de atraso na iniciação da floração masculina para cada hora de incremento do fotoperíodo acima de 12,5 horas.

-P5: duração da etapa reprodutiva, soma térmica desde a emergência do estígma na espiga até o ponto de maturidade fisiológica do grão (temperatura base $\left.8^{\circ} \mathrm{C}\right)$.

-G2: número máximo de grãos por planta.

-G3: taxa de enchimento do grão $\left(\mathrm{mg}\right.$ dia $\left.^{-1}\right)$ sob condições ótimas de crescimento.

-PHY: Intervalo correspondente ao filocron em tempo térmico (graus-dia) entre a aparição de folhas subseqüentes.

O uso de características específicas para cada cultivar geralmente melhora a performance do modelo permitindo analisar a adaptação de uma variedade a diversos ambientes (Jame \& Curtforth, 1996). Por outro lado, a ocorrência das diferentes fases fenológicas descritas no modelo representam intervalos de crescimento da planta delimitados por diferentes eventos fisiológicos. O sistema de numeração das fases é circular como se descreve no Quadro 1 (Kiniry, 1991). 


\begin{tabular}{cl}
\hline Fase $\mathbf{n}^{\mathbf{0}}$. & Descrição da fase \\
\hline 7 & Pré-semeadura \\
8 & Semeadura à germinação \\
9 & Germinação à emergência das plântulas \\
1 & Emergência das plântulas ao final da etapa juvenil \\
2 & Final da etapa juvenil à iniciação da floração masculina (fase \\
& sensível ao fotoperíodo) \\
3 & Iniciação da floração masculina à emergência do estígma na \\
4 & espiga \\
& Emergência do estígma na espiga ao começo do enchimento do \\
5 & Período do enchimento do grão \\
6 & Final do período efetivo de enchimento do grão ao ponto de \\
& maturidade fisiológica (ponto preto)
\end{tabular}

Quadro 1 - Descrição das fases fenológicas para a cultura de milho usadas no modelo CERES-Maize.

As principais condições de contorno do modelo referentes à fenologia do milho são descritas a seguir, de acordo com Kiniry (1991):

- A temperatura base, isto é, a temperatura sob a qual o crescimento é limitado, é de $8^{\circ} \mathrm{C}$ para todas as fases, exceto para a fase de germinação à emergência que é de $10^{\circ} \mathrm{C}$.

- Quando a disponibilidade de água no solo não é limitante, a duração da fase semeadura-emergência requer um dia até a germinação e logo após uma soma térmica de $45^{\circ} \mathrm{Cdia}$ (base 10) para a emergência da planta com uma profundidade de semeadura de $5 \mathrm{~cm}$.

- A velocidade do desenvolvimento de várias fases incrementa-se linearmente desde a temperatura base até $34^{\circ} \mathrm{C}$, depois decresce linearmente até zero quando a temperatura aumenta de $34 \mathrm{a} 44^{\circ} \mathrm{C}$. De forma semelhante, assume-se que a 
taxa de iniciação de folhas e aparecimento de ápices foliares muda linearmente entre as duas faixas de temperatura.

- Durante a fase juvenil, tanto a taxa de iniciação de primórdios como a duração dessa fase é dependente da temperatura.

- Uma vez que a soma térmica do coeficiente genético P1 tenha sido alcançada, o desenvolvimento do ápice é independente da temperatura e começa a etapa sensível ao fotoperíodo. Para fotoperíodos maiores que 12,5 horas, o retardamento produzido na data de floração masculina é calculado com o coeficiente genético P2 (sensibilidade ao fotoperíodo) e o valor de fotoperíodo.

- A data de floração masculina é calculada pela soma térmica e pelo efeito do fotoperíodo.

- Três fases entre a emergência da espiga e o ponto de maturidade fisiológica são simuladas: a) fase inicial denominada "lag" $\left(170^{\circ} \mathrm{Cdia}\right)$; b) fase de crescimento linear que se finaliza quando $95 \%$ dos graus-dia necessários tenham sido acumulados; c) fase final que requer os 5\% restantes dos graus-dia. De acordo com dados experimentais de campo, a soma térmica de $\mathrm{P} 3$ varia de 665 até $940^{\circ} \mathrm{Cdia}$ (base $\left.8^{\circ} \mathrm{C}\right)$.

\section{6 Aplicações dos modelos CERES}

No Brasil, o modelo CERES-Maize foi testado por Liu et al. (1989), utilizando dados meteorológicos, de solo e da cultura de milho híbrido DINA 10, coletados no Centro Nacional de Pesquisa de Milho e Sorgo (EMBRAPA-CNPMS), localizado em Sete Lagoas, MG. Com base nesses dados, foi feita uma comparação entre rendimento observado e o simulado para um período de cinco anos (1983-1987). Os parâmetros genéticos da cultura obtidos em 1983 (ano da calibração) foram usados para simular os dados dos próximos quatro anos (1984, 1985, 1986 e 1987). Os resultados mostraram que as datas simuladas e observadas, da emergência até o final do estádio juvenil, apresentaram uma diferença média de três dias, enquanto as datas do florescimento até o ponto de maturidade fisiológica tiveram uma diferença média de menos de um dia. $\mathrm{O}$ 
estudo mostrou que o modelo gerou estimativas úteis de rendimento do milho para um local específico, tendo os autores sugerido a aplicação desse modelo para a estimativa de rendimento em outros locais do Brasil.

Bowen et al. (1993) testaram o modelo CERES-Maize utilizando dados de experimentos conduzidos na EMBRAPA/CPAC no Distrito Federal, Brasil. A rotina de nitrogênio desse modelo foi avaliada com relação à simulação da disponibilidade de $\mathrm{N}$ após a incorporação de adubos verdes. $\mathrm{O}$ sub-modelo simulou moderadamente bem a liberação de $\mathrm{N}$, porém, ficou evidenciada a necessidade de se realizar outros trabalhos, para se determinar a importância da retenção de nitrato no subsolo e de como essa retenção pode ser descrita no modelo.

Lima (1995) avaliou o modelo CERES-Maize através da calibração, teste e análise de sensibilidade dos principais parâmetros envolvidos, com dados observados em experimentos de campo em Piracicaba, Estado de São Paulo. As simulações realizadas evidenciaram que o crescimento, desenvolvimento da planta e o rendimento de grãos foram estimados satisfatoriamente.

O modelo CERES-Maize foi usado por Thornton et al. (1995) para simular o crescimento e o rendimento do milho no período 1989-1992 em Malawi (Sudeste da África). A avaliação do modelo revelou sua capacidade em simular o rendimento com razoável precisão em uma ampla faixa de condições ambientais. Após a avaliação, os autores utilizaram o modelo para definir épocas de semeadura para os diferentes locais onde os experimentos de campo foram conduzidos, identificar populações ótimas, manejo adequado da fertilização nitrogenada e avaliar economicamente o uso de fertilizante e o risco climático na produção do milho. Nesse estudo utilizou-se o acoplamento do modelo a um Sistema de Informação Geográfica (GIS) para realizar análises regionais e apresentar informações espacializadas.

Soler et al. (2001) simularam o crescimento e desenvolvimento do milho "safrinha" com o modelo CERES-Maize, sob condições de sequeiro e de irrigação em duas regiões do Estado de São Paulo, Ribeirão Preto e Manduri, com o objetivo de se conhecer as características genéticas desejáveis das cultivares e as épocas de semeadura que proporcionassem a melhor performance da cultura durante o período da entressafra. 
A fim de se avaliar o efeito de diferentes características agronômicas e físiológicas da cultura possíveis de melhoramento genético, foram alterados os coeficientes genéticos considerando-se diferentes condições de manejo e a variabilidade climática das regiões estudadas.

Cardoso (2001) utilizou o modelo CERES-Maize para determinar estratégias otimizadas de irrigação e analisar o risco decorrente de adversidades climáticas associadas à cultura de milho "safrinha" em duas localidades do estado de Paraná.

Heinemann (2001) combinou modelos de crescimento (DSSAT) com sistemas de informação geográfica (SIG AEGIS/WIN) para determinar, a nível regional, as necessidades hídricas, assim como a quantidade anual de água utilizada para irrigação, escoamento superficial, e nitrogênio lixiviado para as culturas mais importantes (milho e feijão) da bacia do Rio Tibagi, no Estado do Paraná.

Castelán-Ortega et al. (2003) utilizaram o modelo CERES-Maize para simular a produção de milho sob três diferentes sistemas de manejo no México. O modelo foi associado a um outro modelo de simulação do sistema de produção leiteira. Identificaram-se sistemas de produção que maximizam a receita líquida dos agricultores.

Hoogenboom e White (2003) relatam que os modelos de simulação do crescimento e desenvolvimento das culturas tem sido pouco usados como ferramenta de ajuda no melhoramento de plantas, devido em parte às restrições dos modelos para representar as diferenças genéticas. No entanto, avanços na área genética sugerem à possibilidade de uso dessas informações sobre a ação de determinados genes para melhorar os modelos de simulação (White \& Hoogenboom, 2003; Hunt et al., 2001; Hunt et al., 2003).

\section{7 Estimativa de rendimento}

Muitos modelos de culturas tem sido usados em estudos de avaliação dos riscos na agricultura, por exemplo, estudos de variabilidade de rendimento numa série de anos. Os modelos de simulação são uma excelente ferramenta para estudos associados a variabilidade climática. As simulações podem ser realizadas visando atualizar saídas do 
modelo através da estação de crescimento, utilizando-se dados climáticos recentes. $\mathrm{O}$ que é interessante é conhecer a distribuição dos resultados ao longo do tempo enquanto que os dados climáticos subseqüentes são substituídos por dados históricos observados.

Em simulações realizadas mais perto do final da estação de crescimento é de se esperar menor grau de incerteza no rendimento a se obter. A variabilidade no rendimento também deveria diminuir até a variância ser próxima de zero quando todos os dados climáticos desconhecidos forem substituídos pelos dados observados ao longo da estação de crescimento (Thornton et al., 1997). Se fosse possível obter estimativas confiáveis de rendimento dois messes antes da colheita, os tomadores de decisões poderiam ter tempo hábil para tomar as medidas necessárias. Por exemplo, numa boa estação, com rendimentos superiores à média, seria necessário verificar a existência de espaço suficiente para o armazenamento do milho.

Duchon (1986) utilizou o modelo CERES-Maize para desenvolver um esquema operacional de previsão de safra do milho nos 14 estados que compõem o "cinturão do milho" dos Estados Unidos. A técnica consiste em usar dados climatológicos médios diários de uma série de anos (temperatura do ar, radiação solar e precipitação) para representarem o tempo meteorológico futuro. Esses dados vão sendo substituídos por dados meteorológicos observados no ano em questão, de acordo com o desenvolvimento da cultura. Os resultados mostraram que a variância associada à previsão foi relativamente constante até o florescimento, diminuindo até próximo de zero com o avanço do ciclo. No ponto de maturidade fisiológica da cultura do milho, o governo já tem uma estimativa satisfatória da safra, antes mesmo de iniciar a colheita, podendo a partir daí tomar as decisões pertinentes quanto ao transporte, armazenamento, política de preços e exportação do produto.

Chipanshi et al. (1997) utilizaram o modelo CERES-Wheat para previsão de safra do trigo numa região do Canadá. Foram utilizados dados climatológicos médios diários de uma série de anos, os quais eram substituídos com dados meteorológicos observados de acordo com o desenvolvimento da cultura. Os resultados das simulações do rendimento utilizando esse método equipararam-se com os resultados medidos, 
concluindo que o modelo CERES-Wheat pode ser utilizado como indicativo do rendimento a se obter na região.

Bannayan et al. (2003) também utilizaram o modelo CERES-Wheat para previsão de rendimento de trigo na Inglaterra, e concluíram que o modelo foi capaz de predizer adequadamente os limites superior e inferior de rendimento observado, em vários locais e vários anos, quando as plantas de trigo se encontravam no estado de grão leitoso. 


\section{3 ÍNDICES BIOMETEOROLÓGICOS PARA A CARACTERIZAÇÃO DO DESENVOLVIMENTO FENOLÓGICO DE QUATRO HÍBRIDOS DE MILHO SEMEADOS NA "SAFRINHA", NO ESTADO DE SÃO PAULO}

\section{Resumo}

Um método comum de se descrever a fenologia do milho durante a fase vegetativa é aquele baseado na contagem do número de folhas. O tempo térmico entre a aparição de folhas sucessivas, ou filotermo (do inglês phyllotherm) é crítico para a predição da duração do período vegetativo. Em geral, há uma alta correlação entre o número final de folhas e a duração de período desde a semeadura ao florescimento. $\mathrm{O}$ desenvolvimento de uma cultura depende da temperatura e do fotoperiodo e nesse sentido, índices biometeorológicos são necessários para descrever esse processo. $\mathrm{O}$ objetivo deste estudo foi obter um melhor conhecimento do filotermo e de seu impacto no número final de folhas da cultura do milho semeado na "safrinha". Um segundo objetivo foi avaliar três índices biometeorológicos, baseados na temperatura do ar, para a predição da duração dos sub-períodos semeadura-florescimento feminino e florescimento femininomaturidade fisiológica, em quatro híbridos de milho semeados na "safrinha" no Estado de São Paulo, Brasil. O índice térmico geral (ITG) foi comparado com o índice clássico do tempo térmico (TT), considerando-se duas temperaturas bases: $8^{\circ} \mathrm{C}\left(\mathrm{TT}_{(8)}\right)$ e $10^{\circ} \mathrm{C}$ $\left(\mathrm{TT}_{(10)}\right)$. Três experimentos de campo envolvendo quatro híbridos de diferentes ciclos foram conduzidos durante o outono e inverno de 2001 e 2002 em Piracicaba, SP. A fenologia foi determinada diariamente. Além disso, os três índices biometeorológicos foram testados com dados independentes, provenientes dos ensaios de competição de cultivares conduzidos pelo "Instituto Agronômico" em 5 locais do Estado de São Paulo: Capão Bonito, Guaíra, Pedrinhas Paulista, Ribeirão Preto e Tarumã. 
Os resultados indicaram que o valor do filotermo variou em torno de $50{ }^{\circ} \mathrm{Cd}$ até a aparição da $12^{\mathrm{a}}$ folha, aproximadamente, e depois decresceu. Para estimativa do subperíodo semeadura-florescimento feminino, o índice $\mathrm{TT}_{(10)}$ resultou em um coeficiente de variação $(\mathrm{CV})$ de $2,1 \%$, enquanto que para o índice de $\mathrm{TT}_{(8)} \mathrm{o} \mathrm{CV}$ foi de $1,37 \%$ e para o ITG modificado de $1,04 \%$. O maior coeficiente de determinação $\left(r^{2}=0,63\right)$ dos três índices estudados foi obtido entre o ITG modificado e o número de dias entre a semeadura e o florescimento feminino. Para o sub-período florescimento femininomaturidade fisiológica, o CV foi de 2,91\% para o índice $\mathrm{TT}_{(10)}$, de 2,64\% para o índice $\mathrm{TT}_{(8)}$ e de 2,01\% para o índice do ITG modificado. Pode-se concluir, a partir deste estudo, que o índice ITG modificado pode ser utilizado para a estimativa dos subperíodos semeadura-florescimento feminino e florescimento feminino-maturidade fisiológica do milho semeado na "safrinha" nas regiões subtropicais do Brasil, pois apresentou o menor $\mathrm{CV}$ e o maior coeficiente de determinação quando correlacionado com a duração desses sub-períodos, em dias. No entanto, estudos com outros híbridos são necessários para se confirmar os avanços na estimativa das fases fenológicas baseadas no ITG modificado.

\section{Summary}

A common method to describe maize phenology during the vegetative phase is by counting the number of leaves. The thermal interval between leaf appearance, called phyllotherm, is critical for predicting the duration of vegetative development. In general, there is a high correlation between the final number of initiated leaves and the duration from sowing to silking. The development of a crop depends on temperature and photoperiod, thus bio-meteorological indices are needed to describe this process. The goal of this study was to obtain a better understanding of the phyllotherm and its impact on the final number of leaves. A second objective was to evaluate three thermal indices for predicting the duration of sowing to silking and silking to physiological maturity for four maize hybrids grown off-season in a subtropical region of the Southern Hemisphere (São Paulo State, Brazil). The modified general thermal index (GTI) was compared with the classical thermal time concept (TT) with two sets of cardinal temperatures, including 
$\mathrm{TT}_{(10)}$ with $10^{\circ} \mathrm{C}$ as minimum base temperature $(\mathrm{Tb})$ and $\mathrm{TT}_{(8)}$ with $8^{\circ} \mathrm{C}$ as $\mathrm{Tb}$. Three field experiment involving four hybrids of different maturity duration were conducted during the autumn and winter growing seasons of 2001 and 2002 at the University of São Paulo, in Piracicaba, SP, Brazil. Phenology was recorded on a daily basis. Also, independent evaluation of the three methods to estimate phenology was conducted with data obtained from the variety trials conducted by "Instituto Agronômico" in five regions of the State of São Paulo, Brazil. The results indicated that the value for the phyllotherm varied around $50{ }^{\circ} \mathrm{Cd}$ until the appearance of the $12^{\text {th }}$ leaf, approximately, and then declined. For estimating the planting to silking period, the $\mathrm{TT}_{(10)}$ method resulted in a coefficient of variation $(\mathrm{CV})$ of $2.01 \%$, while for $\mathrm{TT}_{(8)}$ the $\mathrm{CV}$ was $1.37 \%$, and for modified GTI the CV was $1.04 \%$. The highest determination coefficient $\left(\mathrm{r}^{2}=\right.$ 0.63 ) of the three methods was found between values of the modified GTI and number of days from planting to silking. For the period from silking to physiological maturity, the $\mathrm{CV}$ was $2.91 \%$ for the $\mathrm{TT}_{(10)}, 2.64 \%$ for the $\mathrm{TT}_{(8)}$, and $2.01 \%$ for the modified GTI method. It can be concluded from this study that the modified GTI can be used to estimate both silking and physiological maturity dates in maize grown off-season in subtropical regions of Brazil, because it had the smallest CV and the highest coefficient of determination when correlated with duration (in days) of these phases. However, studies with more maize hybrids should be done to confirm the advances in estimating the main phenological phases based on modified GTI.

\subsection{Introdução}

Nos últimos anos, o milho "safrinha" tem sido umas das principais alternativas de culturas de outono e inverno nas Regiões Centro-Oeste e Centro-Sul do Brasil, por ocupar boa parte das terras ociosas e pelo elevado preço na época da colheita, que coincide com a entressafra. Entretanto, o milho neste período é caracterizado por um alto risco, devido principalmente à variabilidade da precipitação e de outros elementos climáticos, como as geadas, que tem impacto no crescimento e desenvolvimento da cultura. 
Para a predição da duração do desenvolvimento vegetativo, o intervalo entre aparição de folhas medido em tempo térmico, conhecido como filotermo, é extremamente importante (Birch et al., 1998b). De acordo com Bonhomme (2000), o filocron é a duração medida em unidade de tempo entre a aparição de folhas sucessivas, enquanto que o filotermo é a soma de graus-dias correspondente a este período. $\mathrm{O}$ filotermo varia entre ambientes tropicais, temperado-quente e temperado-frio. Segundo Kiniry e Bonhomme (1991), o filotermo é cerca de 30\% maior em ambientes tropicais do que em regiões temperadas. De acordo com Tollenaar (1988), o filotermo é relativamente constante quando expresso em termos de unidades térmicas durante o período de crescimento das folhas, desde a semeadura até a aparição da última folha. $\mathrm{Na}$ maioria dos casos, o filotermo é único para cada cultivar e supostamente constante, independentemente da temperatura da região. No entanto, muitos pesquisadores tem verificado que o filotermo não é constante para milho e para outras espécies, mas que ele é dependente das condições ambientais durante a fase de crescimento vegetativo (McMaster e Wilhelm, 1995; Rickman e Klepper, 1995; Jame et al., 1999). Os fatores ambientais que afetam a aparição de folhas em algumas gramíneas incluem a água, os nutrientes, a salinidade, a intensidade luminosa e o tamanho da semente (Friend et al. 1965; Baker et al. 1986; Peterson, et al., 1989; Mass e Grieve, 1990; Curtfoth, et al. 1992; Longnecker, et al. 1993; LeCain, et al. 1992). Porém, a temperatura é o fator mais importante a determinar a taxa de aparição de folhas, enquanto que os efeitos dos demais fatores ambientais são ainda bastante contraditórios. Por exemplo, alguns pesquisadores verificaram que o estresse hídrico e nutricional tem pouco efeito na taxa de aparição de folhas (Bauer et al., 1984; Hotsonyame e Hunt, 1997), ao passo que outros tem mostrado que tais estresses podem tanto aumentar como diminuir a taxa de aparição de folhas (Cutforth et al., 1992).

Muitos modelos de simulação usam o valor do filotermo como dado de entrada para simular a taxa de aparição de folhas e o número total de folhas por planta (Jones e Kiniry, 1986). Ambas variáveis fisiológicas afetam a duração do período vegetativo do milho. Para o planejamento de práticas agronômicas na cultura de milho "safrinha", como a aplicação de fertilizantes e herbicidas em função do desenvolvimento da cultura, 
é importante se dispor de metodologia para predizer os diferentes estágios fenológicos. Além disso, dados fenológicos podem ser utilizados como indicadores da viabilidade de uma dada cultivar numa determinada região e, ainda, como guia para o desenvolvimento de cultivares em ambientes específicos.

Em geral, os índices biometeorológicos, baseados na temperatura do ar, descrevem a taxa de desenvolvimento das culturas mais precisamente do que o tempo expresso em dias. Um índice ideal seria aquele capaz de estimar, para um dado genótipo, um número constante de unidades térmicas para atingir um estágio específico de desenvolvimento, na ausência de outros fatores limitantes ao desenvolvimento, como fotoperíodo, água e nutrientes. Ainda, deveria considerar diferentes funções de temperatura para os períodos vegetativo e reprodutivo, sendo assim mais preciso para predizer a fenologia do que a utilização de uma única função para os dos períodos (Dwyer et al., 1999). A maioria das evidencias indicam que a resposta fenológica à temperatura corresponde a uma função sigmoidal para o período vegetativo do milho (Muchow e Carberry, 1989; Shaykewich, 1995; Ellis et al., 1992; Yin et al., 1995; Jame et al., 1999; Bonhomme, 2000; Kim et al., 2003). Stewart et al. (1998) encontraram que uma função ajustada reduziu em $50 \%$ os erros padrões, ao estimar o sub-período semeadura-maturidade, quando comparado com o método clássico, baseado no tempo térmico, expresso em termos de graus-dia.

Diante do exposto acima, o objetivo principal do presente estudo foi investigar o desenvolvimento fenológico de quatro híbridos de milho, com ciclos de diferentes durações, semeados na "safrinha" no Estado de São Paulo, Brasil. Os objetivos específicos foram: a) estudar o valor do filotermo em função do crescimento e desenvolvimento da cultura, procurando-se ter um melhor entendimento da aparição de folhas e sua influencia no número final de folhas; b) analisar a relação entre o número de folhas e a duração do período vegetativo; c) comparar o índice térmico geral (ITG) modificado com o índice térmico clássico, usando-se duas diferentes temperaturas base para predição do florescimento feminino e da maturidade fisiológica; d) avaliar esses índices biometeorológicos para o sub-período semeadura-florescimento em cinco diferentes regiões climáticas do Estado. 


\subsection{Materiais e métodos}

\subsubsection{Experimentos de campo}

Três experimentos de campo com quatro híbridos de milho foram conduzidos na Escola Superior de Agricultura "Luiz de Queiroz", Universidade de São Paulo, em Piracicaba ( $22^{\circ} 43^{\prime}$ latitude Sul, $47^{\circ} 25^{\prime}$ longitude Oeste, $580 \mathrm{~m}$ acima do nível do mar), no Estado de São Paulo, Brasil, durante os anos de 2001 e 2002. O clima da região, de acordo com a classificação de Köppen, é Cwa: subtropical com verão chuvoso e inverno seco. O solo da área experimental é classificada como Terra Roxa Estruturada. Um experimento foi conduzido no ano 2001 sob condições irrigadas e os outros dois no ano 2002: um sob condições de sequeiro e outro sob irrigação. Todos os experimentos tiveram delineamento de blocos completos ao acaso com três repetições durante o ano 2001 e quatro repetições durante o ano 2002. Os híbridos de milho utilizados neste estudo foram: AG9010 (ciclo super precoce), DAS CO32 e Exceler (ciclo precoce) e DKB 333B (ciclo normal). Estes híbridos produzem normalmente altos rendimentos e boa qualidade de grãos (semi-duro) sendo aceitáveis no mercado brasileiro, além de não serem muito susceptíveis às principais doenças foliares.

As datas de semeadura foram 15 de março para o experimento de 2001 e 13 de março para os experimentos conduzidos em 2002. As semeaduras foram feitas com espaçamento de $0,8 \mathrm{~m}$ entre linhas e com densidade final de 4 plantas por metro linear. Todos os experimentos foram fertilizados na semeadura com NPK, fórmula 8-28-16 (380 $\mathrm{kg} \mathrm{ha}^{-1}$ para os experimentos irrigados e $250 \mathrm{~kg} \mathrm{ha}^{-1}$ para o experimento em condições de sequeiro), e com uréia (108 $\left.\mathrm{kg} \mathrm{ha}^{-1}\right)$ nos estágios V5-V6. Além disso, os experimentos irrigados foram fertilizados com uréia $\left(108 \mathrm{~kg} \mathrm{ha}^{-1}\right)$ no estágio V10.

As plantas daninhas foram controladas com herbicidas pré-emergentes na semeadura e removidas manualmente durante a estação de crescimento. A principal praga, a lagarta do cartucho (Spodoptera frugiperda) foi controlada com piretroides e com inseticidas organofosfatados. 
Nos experimentos irrigados, a aplicação de água se deu por meio do sistema de pivô central e a umidade do solo foi monitorada com três conjuntos de tensiômetros instalados a quatro profundidades: 20,40, 55 e $70 \mathrm{~cm}$. Dados de temperatura máxima e mínima do ar, precipitação e radiação solar foram obtidos de uma estação meteorológica automática, situada nas proximidades do campo experimental. Durante o período do outono e inverno, um decréscimo na radiação solar, na precipitação, no número de dias com chuva e na temperatura são comuns na região (Figura 1).

\subsubsection{Avaliações biométricas}

Duas plantas por parcela foram selecionadas para se avaliar a aparição de folhas. A aparição de folhas foi registrada com o aparecimento da lígula. O número de lígulas visíveis foi registrado em cada parcela diariamente. Cada nova folha que aparecia era marcada com um cordão visando à contagem das folhas e ao monitoramento das folhas senescentes na parte inferior das plantas.

O florescimento foi registrado quando os estigmas eram visíveis na espiga em $50 \%$ das plantas de cada parcela. A maturidade fisiológica foi determinada amostrandose regularmente duas espigas por parcela, para identificar a presença da camada preta na base do grão, indicando o término do acúmulo de biomassa no grão. 

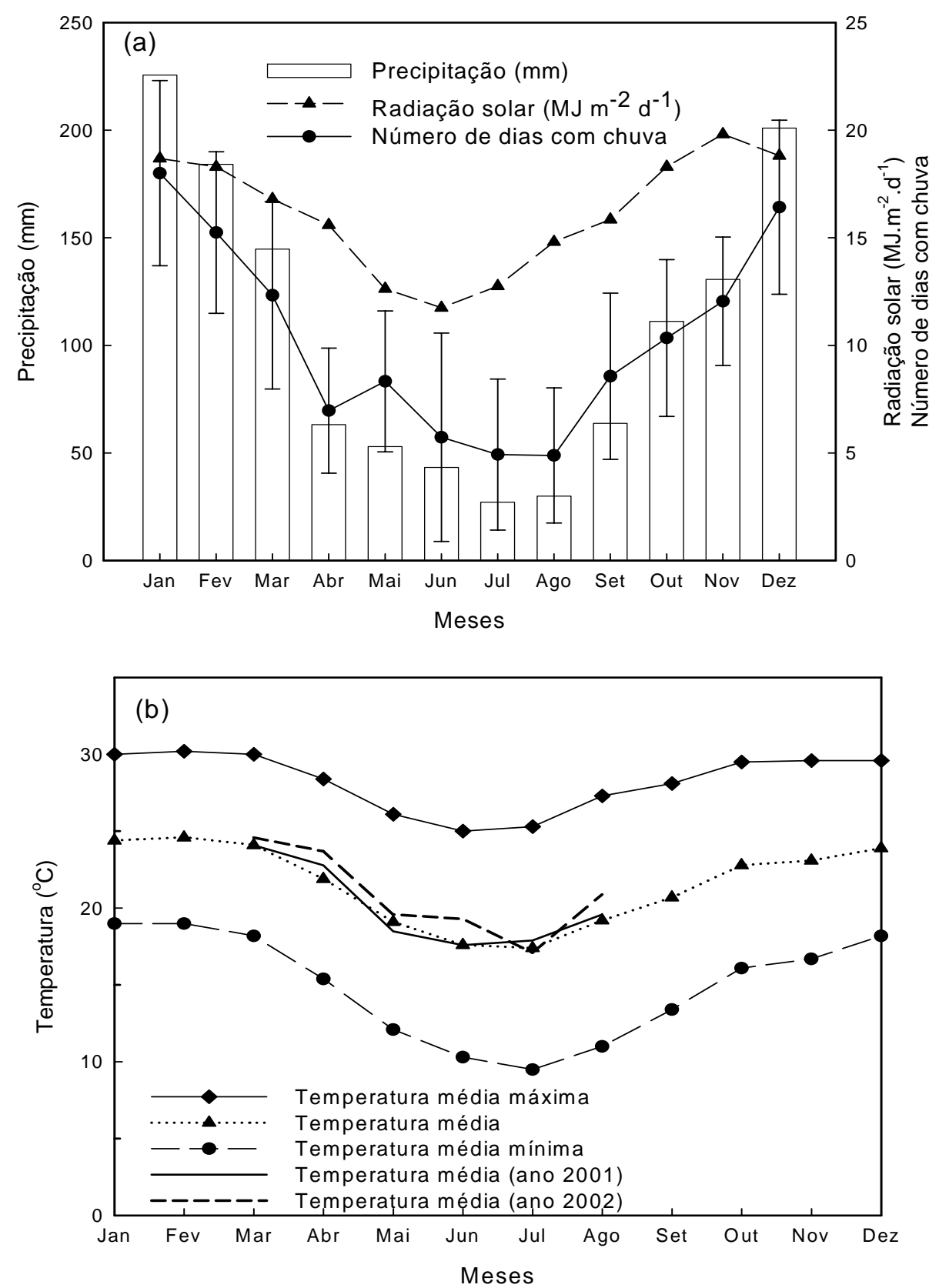

Figura 1 - Caracterização climática da região de Piracicaba, Estado de São Paulo, Brasil: a) radiação solar média, precipitação total mensal média, número médio de dias com chuva e respectivo desvio padrão; b) valores normais da temperatura máxima, média, e mínima do ar e temperatura média do ar durante as estações de crescimento do milho nos anos 2001 e 2002. Fonte: DCE/ESALQ/USP. 


\subsubsection{Cálculo dos índices biometeorológicos}

O filotermo foi calculado desde o estágio de duas folhas até o florescimento masculino, baseado em dados registrados de aparição de folhas e assumindo-se relação linear entre a temperatura e a taxa de desenvolvimento. $\mathrm{O}$ filotermo, expresso em grausdia, foi calculado pela Equação 1:

$\mathrm{TT}=\sum_{\mathrm{j}=1}^{\mathrm{n}}\left(\frac{\mathrm{T} \max +\mathrm{T} \min }{2}\right)-\mathrm{Tb}$

em que: Tmax é a temperatura máxima diária, Tmin a temperatura mínima diária, Tb a temperatura base no qual o desenvolvimento se interrompe, todas em ${ }^{\circ} \mathrm{C}$, e $\mathrm{n}$ o número de dias com observações de temperatura utilizadas na somatória. Tb foi assumida como sendo igual a $8^{\circ} \mathrm{C}$ (Barbano et al., 2001).

Usualmente, o milho "safrinha" é semeado após uma cultura de verão, aproveitando-se as chuvas que ocorrem no final dessa estação, antes do começo da estação seca, que normalmente ocorre nos meses de outono e inverno (Esteves et al., 1994). Assim, assumiu-se, neste estudo, que o conteúdo de água no solo nessa época do ano era adequado para a emergência da cultura. Conseqüentemente, estudou-se o subperíodo semeadura-florescimento feminino na sua totalidade.

A Equação 1 foi também utilizada para calcular o tempo térmico (TT) para os sub-períodos semeadura-florescimento feminino e florescimento feminino-maturidade fisiológica (Cross e Zuber, 1972, Kiniry, 1991; Hodges e Evans, 1992; McMaster e Wilhelm, 1997; Barbano et al., 2001) considerando-se duas temperaturas base diferentes (Tb): $8^{\circ} \mathrm{C}$ e $10^{\circ} \mathrm{C}$, as mais freqüentemente encontradas em estudos brasileiros (Fancelli e Dourado-Neto, 2000; Barbano et al., 2001).

O conceito clássico de tempo térmico para estimativa de fenologia foi comparado com o índice térmico geral (ITG), baseado no modelo de Stewart et al. (1998). O ITG foi desenvolvido a partir de ajustes de funções de resposta do desenvolvimento vegetal à temperatura do ar para as fases vegetativa e de enchimento dos grãos, utilizando-se unidades como a do TT, sendo o ITG calculado pela Equação 2: 
$\mathrm{ITG}=\sum_{\mathrm{i}=1}^{\mathrm{n}} \mathrm{F}_{\mathrm{T}} \Delta \mathrm{t}$

em que: $\Delta$ t é o intervalo de tempo (em dias) e n o número de dias dos sub-períodos semeadura-florescimento feminino e florescimento feminino-maturidade fisiológica.

A função de temperatura $\left(\mathrm{F}_{\mathrm{T}}\right)$, é dada por um polinômio cúbico sem limites de temperatura, como apresentado na Equação 3.

$F_{T}=B_{0}+B_{1} T_{A}^{2}+B_{2} T_{A}^{3}$

em que: $\mathrm{T}_{\mathrm{A}}$ é a temperatura média diária do ar e $\mathrm{B}_{0}, \mathrm{~B}_{1}$ e $\mathrm{B}_{2}$ são coeficientes empíricos do polinômio.

Os valores de $\mathrm{B}_{0}, \mathrm{~B}_{1}$ e $\mathrm{B}_{2}$ que minimizaram o quadrado médio dos desvios (RMSD - Equação 4) entre $\mathrm{TT}_{(8)}$ e ITG foram determinados para cada híbrido e subseqüentemente foram estimados $\mathrm{F}_{\mathrm{T}}$ e o ITG modificado. Assim, os valores de ITG mantiveram magnitude similar aos valores encontrados com o índice $\mathrm{TT}_{(8)}$.

$\operatorname{RMSD}=\left[\left(\sum_{\mathrm{i}=1}^{\mathrm{n}}\left(\mathrm{ITG}-\mathrm{TT}_{(8)}\right)^{2}\right) / \mathrm{n}\right]^{0.5}$

em que n é o número de observações.

\subsubsection{Análise estatística}

Visando se identificar o melhor índice para a estimativa da fenologia do milho "safrinha" na região de estudo, empregou-se a comparação dos coeficientes de variação (CV) entre os três índices utilizados. O índice mais estável para cada híbrido foi considerado ser aquele que apresentou o menor $\mathrm{CV}$, considerando-se os três diferentes experimentos. Como esses resultados podem ser influenciados pela ordem de magnitude das médias, também utilizou-se a análise de regressão para se avaliar os diferentes 
índices biometeorológicos de estimativa da data de florescimento e da maturidade fisiológica em função do tempo térmico.

\subsubsection{Avaliação dos índices biometeorológicos}

Foi conduzida uma avaliação independente dos índices biometeorológicos. Para tanto, dados fenológicos obtidos dos ensaios de competição de cultivares do Instituto Agronômico, em cinco locais do Estado de São Paulo em diferentes anos: Capão Bonito

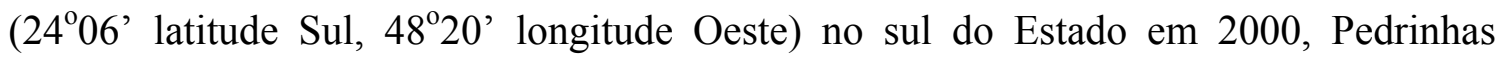

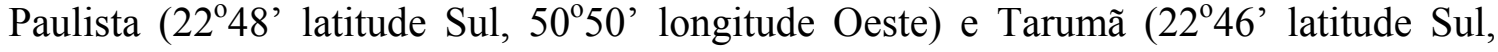
$50^{\circ} 36^{\prime}$ longitude Oeste) no oeste do Estado respectivamente em 2001 e 2000, e Guaíra

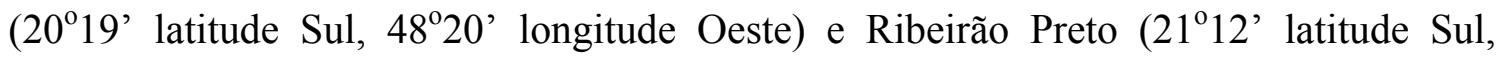
$47^{\circ} 50^{\prime}$ longitude Oeste) na região norte do Estado repectivamente em 1998 e 2000. Esses dados foram utilizados para a determinação do $\mathrm{CV}(\%)$ para os índices do ITG modificado, $\mathrm{TT}_{(8)}$ e $\mathrm{TT}_{(10)}$ para três dos híbridos estudados, entre os quais DKB 333B, DAS CO32 e Exceler. Para o híbrido de ciclo super precoce AG9010, não haviam informações disponíveis nos locais estudados e, portanto, este não foi utilizado nesta avaliação. A análise de regressão também foi empregada, para se correlacionar a duração, em dias, desde a semeadura ao florescimento e os tempos térmicos obtidos com os índices ITG modificado, $\mathrm{TT}_{(8)}$ e $\mathrm{TT}_{(10)}$. Informações referentes à maturidade fisiológica também não estavam disponíveis.

\subsection{Resultados e discussão}

\subsubsection{Número de folhas}

O híbrido AG9010, de ciclo super-precoce, produziu o menor número de folhas $(17,7)$, enquanto que o híbrido DKB 333B, híbrido de ciclo normal, produziu o maior número de folhas $(20,9)$ (Tabela 1). Os híbridos de ciclo curto, DAS CO32 e Exceler, produziram um número intermediário de folhas, ao redor de 20 . O desvio padrão variou entre 0,0 para o híbrido DKB 333B, de ciclo normal, no experimento sob irrigação no ano 2002, até 1,2 para esse mesmo híbrido no experimento do ano 2001. Houve um 
maior número de folhas no ano 2002 sob condições de sequeiro em comparação com o experimento realizado sob condições irrigadas no mesmo ano. Resultados similares foram encontrados por Muchow e Carberry (1989), os quais associaram isso ao estresse hídrico ocorrido nos estágios iniciais da cultura.

Tabela 1 - Número final de folhas e respectivo desvio padrão para quatro híbridos de milho semeados na "safrinha" em Piracicaba, SP, Brasil.

\begin{tabular}{lcccc}
\hline Híbrido & \multicolumn{3}{c}{ Número de folhas } \\
& Irrigado 2001 & Irrigado 2002 & Sequeiro 2002 & Média \\
\hline DKB 333B & $19,3 \pm 1,2$ & $21,0 \pm 0,0$ & $22,5 \pm 1,0$ & $20,9 \pm 0,73$ \\
DAS CO32 & $19,3 \pm 0,6$ & $19,8 \pm 1,0$ & $20,5 \pm 0,6$ & $19,9 \pm 0,73$ \\
Exceler & $19,6 \pm 0,6$ & $19,5 \pm 1,0$ & $20,0 \pm 0,8$ & $19,7 \pm 0,80$ \\
AG9010 & $17,6 \pm 0,6$ & $17,8 \pm 0,5$ & $17,8 \pm 0,5$ & $17,7 \pm 0,53$ \\
\hline
\end{tabular}

Houve uma alta correlação $(\mathrm{r}=0,98)$ entre o número final de folhas e a duração do período médio entre a semeadura e o florescimento feminino expresso em dias para os quatro híbridos. Por exemplo, para o híbrido de ciclo normal DKB 333B, a duração média em dias desde a semeadura até o florescimento feminino foi de 66,4 e o número final de folhas foi de 20,9, enquanto que para o híbrido super-precoce AG9010 a duração dessa fase foi de 55,3 dias e o número final de folhas foi de 17,7. Os resultados estão de acordo com estudos prévios que relatam uma alta correlação entre o número final de folhas e a duração do período da semeadura até o florescimento feminino (Chase e Nanda, 1967; Muchow e Carberry, 1989). De acordo com Tollenaar (1988), a duração do período entre a semeadura e o florescimento feminino é fortemente influenciada pelo número final de folhas, já que o crescimento das folhas se dá em grande proporção durante este período. Tollenaar e Hunter (1983) encontraram que o número final de folhas iniciadas depende de um componente genético e de efeitos ambientais durante a fase sensível ao fotoperíodo e à temperatura, que tem sido considerada como abrangendo desde a quarta até a oitava folha. Há evidências de que o milho, por ser uma planta de dia curto, responde a incrementos em fotoperíodo com atraso na iniciação do 
florescimento masculino (Ellis et al., 1992; Warrington e Kanemasu, 1983; Birch et al., 1998a; Tollenaar, 1999). No entanto, não é de se esperar tal resposta na cultura do milho semeado na "safrinha" no Estado de São Paulo, já que a duração do dia nessa região do Brasil é inferior ao fotoperíodo crítico (12,5 horas) e decresce durante esta época do ano, de cerca de $12 \mathrm{~h}$ para 10,6 h.

\subsubsection{Filotermo}

O híbrido AG9010 (super-precoce) teve, em média, um valor de filotermo de $46,1{ }^{\circ} \mathrm{Cd}$, o maior valor dos quatro híbridos nos três experimentos (Tabela 2). O valor mínimo de filotermo foi obtido para o híbrido DKB 333B (ciclo normal) sob condições de sequeiro no ano 2002. Quando se compararam os experimentos conduzidos durante o mesmo ano (2002), o filotermo foi maior sob condições irrigadas do que em condições de sequeiro (Tabela 2). Resultados similares tem sido obtidos para outras espécies de gramíneas nas quais o estresse hídrico reduziu o valor de filotermo (Cuthforth et al., 1992). No presente trabalho, foi verificado que um maior número de folhas foi produzido sob condições de sequeiro do que sob condições irrigadas, no entanto, com um menor valor de filotermo. O desvio padrão do filotermo para todos os híbridos em diferentes experimentos de campo foi ao redor de $20,1{ }^{\circ} \mathrm{Cd}$, indicando uma variação comum desta variável durante o período de crescimento vegetativo. $\mathrm{O}$ valor relativamente alto do desvio padrão é devido principalmente à influencia dos baixos valores de filotermo observados nas últimas folhas formadas. Além disso, problemas metodológicos poderiam explicar em parte tal desvio padrão, principalmente pelo registro da fenologia em base diária. 
Tabela 2 - Média e respectivo desvio padrão para o filotermo de quatro híbridos de milho semeados na "safrinha" em Piracicaba, SP, Brasil.

\begin{tabular}{lcccc}
\hline Híbrido & \multicolumn{2}{c}{ Filotermo ( $\left.{ }^{\mathbf{0} C d}\right)$} \\
& Irrigado, 2001 & Irrigado, 2002 & Sequeiro, 2002 & Média \\
\hline DKB 333B & $44,5 \pm 21,7$ & $43,8 \pm 19,2$ & $39,8 \pm 20,9$ & $42,7 \pm 20,6$ \\
DAS CO32 & $42,8 \pm 22,6$ & $44,7 \pm 20,3$ & $41,7 \pm 23,3$ & $43,1 \pm 22,1$ \\
Exceler & $42,3 \pm 18,6$ & $43,2 \pm 20,9$ & $40,2 \pm 23,1$ & $41,9 \pm 20,9$ \\
AG9010 & $49,1 \pm 17,2$ & $45,0 \pm 23,4$ & $44,1 \pm 20,5$ & $46,1 \pm 20,4$ \\
\hline
\end{tabular}

Os resultados obtidos indicam que os valores do filotermo foram maiores até aproximadamente a $12^{\mathrm{a}}$ folha, decrescendo a partir daí de cerca de $50{ }^{\circ} \mathrm{Cd}$ para menos de $30{ }^{\circ} \mathrm{Cd}$ (Figura 2). Muchow et al. (1990) também observaram tal tendência e aplicaram uma equação exponencial para ajustar o decréscimo do filotermo em função da idade da planta. Muchow e Carberry (1989) encontraram que a taxa de aparição de folhas aumentou exponencialmente com o tempo térmico, e que essa relação foi consistente em todas as datas de semeadura estudadas. A acelerada taxa de aparição das últimas folhas é resultado da rápida expansão dos entrenós (Shaykewich, 1995). Assim, de acordo com as observações do presente trabalho, para predizer a fenologia de milho mais precisamente, as equações que descrevem a taxa de aparição de folhas de milho deveriam levar em conta a mais rápida aparição das últimas folhas. 

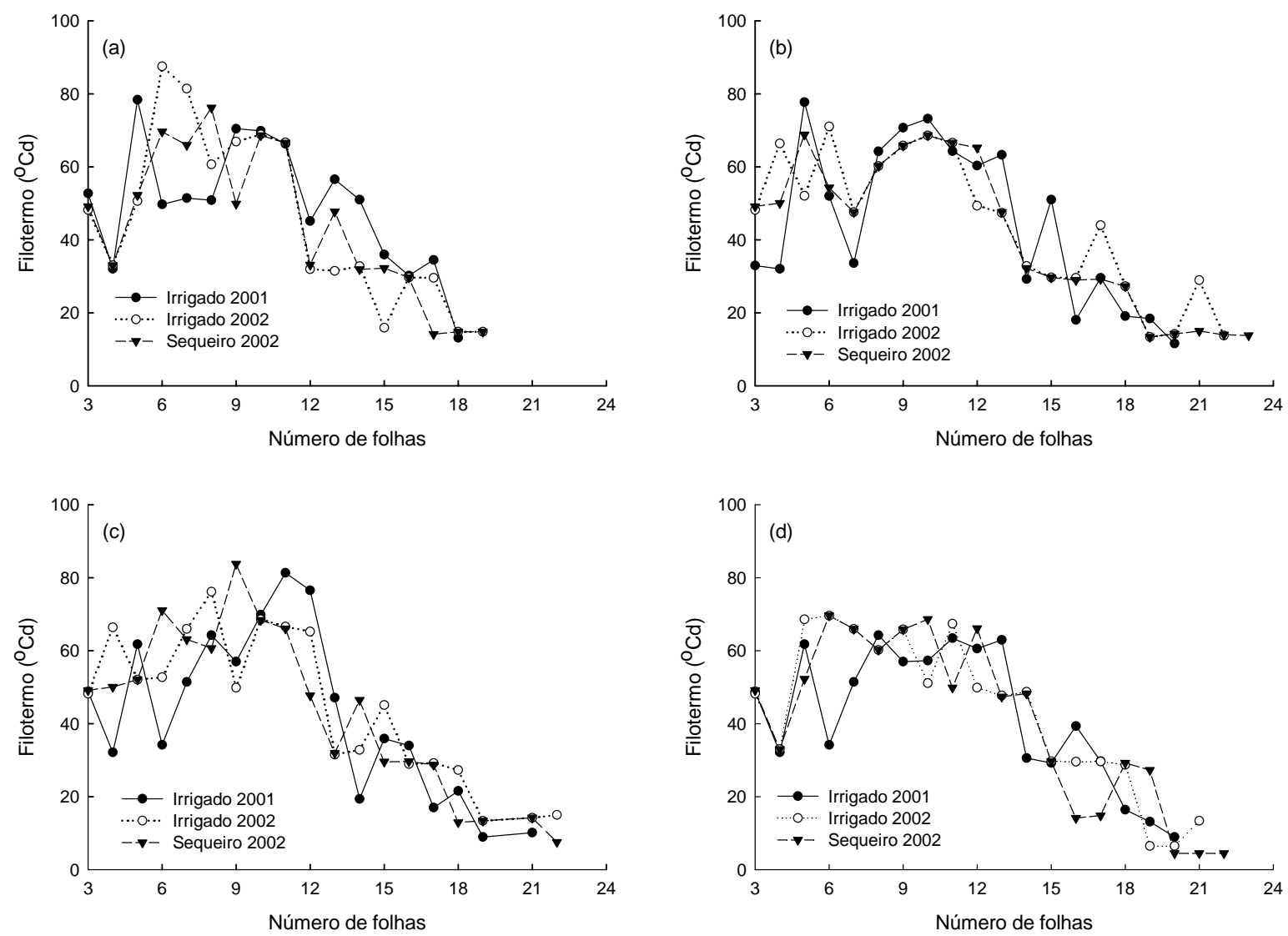

Figura 2 - Variação do filotermo em função do número de folhas para quatro híbridos de milho: a) AG9010, b) DKB 333B, c) DAS CO32 e d) Exceler, semeados na "safrinha" em Piracicaba, SP, Brasil.

Foi encontrada relação linear entre o filotermo e a temperatura média do ar desde a emergência até o florescimento masculino (Figura 3). Elevados valores de filotermo estiveram associados aos valores elevados de temperatura média do ar para os quatro híbridos nos experimentos conduzidos durante o ano 2002. No começo da estação de crescimento a temperatura média do ar foi maior do que nos últimos estágios de desenvolvimento da cultura. Os maiores valores de filotermo foram observados nos estágios iniciais (antes da 12 $2^{\mathrm{a}}$ folha). Para os estágios mais avançados (depois da folha $12^{\mathrm{a}}$ ), os valores de filotermo decresceram, explicando assim a relação positiva entre filotermo e temperatura média do ar. 

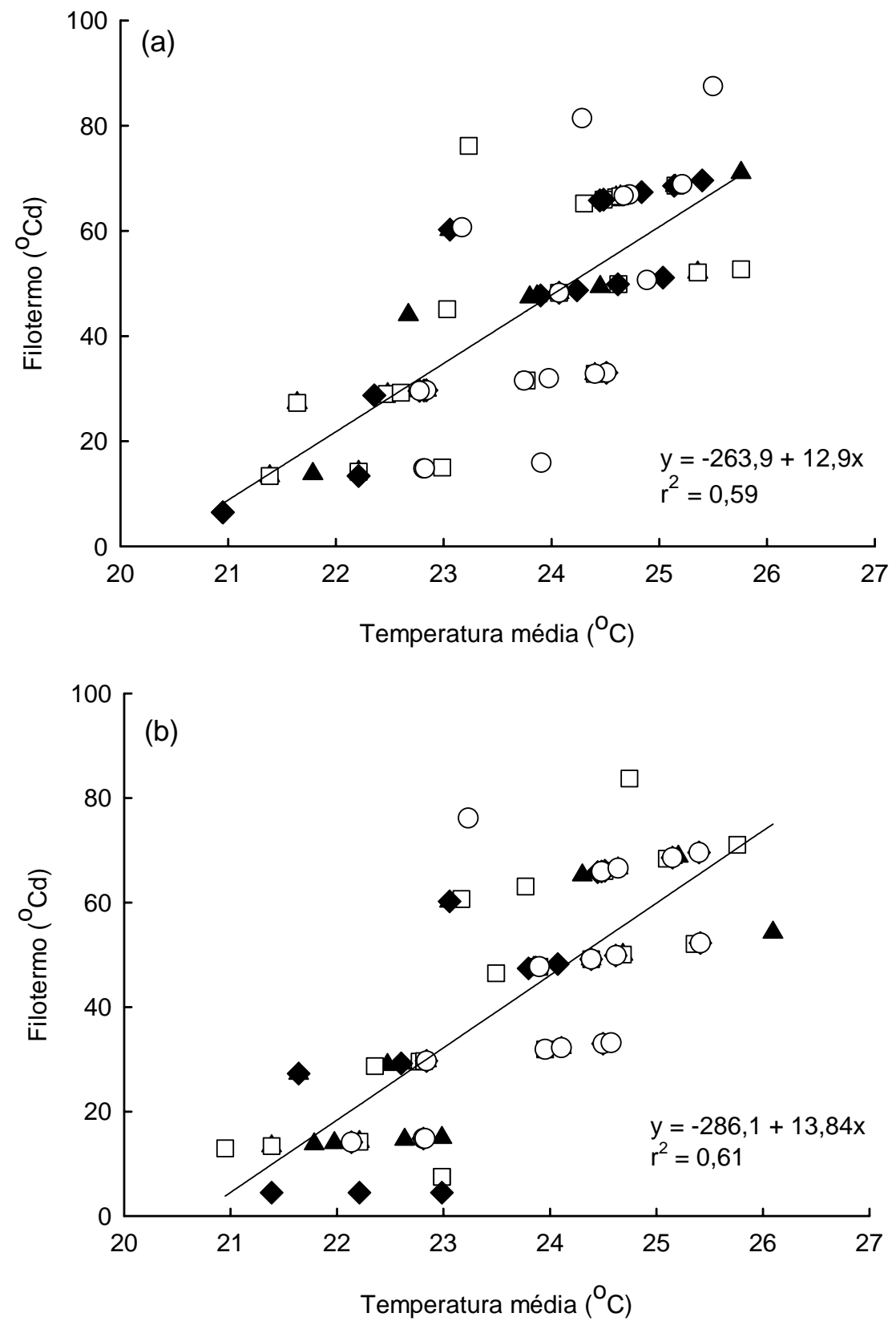

$\Delta$ DKB 333B

$\square \quad$ DAS CO32

- Exceler

O AG9010

Reta de regressão

Figura 3 - Relação entre o filotermo e a temperatura média do ar para os quatro híbridos de milho semeados na "safrinha" de 2002, em Piracicaba, SP, Brasil: (a) sob condições de irrigação, (b) sob condições de sequeiro. 
O filotermo é normalmente determinado com base na temperatura média do ar enquanto que o lugar específico em que a temperatura atua é no ápice da planta. No entanto, a temperatura do ar durante o ciclo da cultura foi medida por uma estação meteorológica automática localizada nas proximidades da estação experimental. Assim, isso poderia ser uma outra fonte de erro na determinação do valor do filotermo. Até que a elongação comece, o meristema apical está situado abaixo da superfície do solo, sendo neste caso a taxa de aparição de folhas mais influenciada pela temperatura do solo do que pela temperatura do ar. A temperatura do solo normalmente é diferente da temperatura do ar, especialmente quando a cobertura vegetal é reduzida (Brooking e McPherson, 1989). Neste estudo, foi considerado somente a temperatura do ar para a determinação do filotermo. Resultados mais precisos poderiam ser obtidos combinandose a temperatura do solo, para as primeiras fases de crescimento da cultura, com temperatura do ar, para as fases mais avançadas de desenvolvimento.

\subsubsection{Funções de resposta à temperatura do ar para o sub-período semeadura-florescimento feminino}

Para o índice ITG modificado, a função de resposta à temperatura teve seu coeficiente B0 considerado igual a zero para o sub-período vegetativo (semeadura florescimento feminino), assim como adotado por Stewart et al. (1998). Os demais coeficientes da equação cúbica para a determinação do ITG modificado, utilizando-se o critério do RMSD (Equação 4) e mantendo-se um valor similar para ITG e $\mathrm{TT}_{(8)}$, foram 0,04848 para o $B_{1}$ e -0,00086 para o $B_{2}$. Empregando-se esses coeficientes empíricos, foi estimada a função de resposta à temperatura para o sub-período semeaduraflorescimento feminino. Durante o crescimento vegetativo, o desenvolvimento do milho respondeu à temperatura média do ar, seguindo uma curva sigmóide, iniciando-se a temperaturas menores do que $5{ }^{\circ} \mathrm{C}$ e com uma resposta máxima por volta dos $38{ }^{\circ} \mathrm{C}$. Na Figura 4a é apresentada as funções de resposta à temperatura média do ar, baseada na Equação 1, para as temperaturas base de $8{ }^{\circ} \mathrm{C}$ e $10{ }^{\circ} \mathrm{C}$. Para temperaturas do ar inferiores a $25{ }^{\circ} \mathrm{C}$, o índice do ITG modificado indica um desenvolvimento mais acentuado do que 
o índice $\mathrm{TT}_{(8)}$, e para temperaturas superiores a $25{ }^{\circ} \mathrm{C}$, ocorre o inverso. Como um todo, o $\mathrm{TT}_{(10)}$ indicou um desenvolvimento mais retardado do que o apresentado pelo índice ITG modificado, para temperaturas menores do que $30^{\circ} \mathrm{C}$.

Para o sub-período semeadura-florescimento feminino, foi encontrada uma elevada correlação entre TT $_{(8)}$ e ITG modificado $(r=0,99)$, com o coeficiente angular da reta de regressão igual a 1,02. O teste estatístico $t$ para a inclinação da reta foi significativo ao nível $0,05, \mathrm{t}(11)=27,5, \mathrm{p}=0,0001$. Assim, foi rejeitada a hipótese nula e concluiu-se que houve uma relação significativa entre $\mathrm{TT}_{(8)}$ e o índice ITG modificado, com o intercepto não sendo estatiscamente diferente de zero. Em resumo, o objetivo de encontrar valores similares para os índices $\mathrm{TT}_{(8)}$ e ITG foi atingido pois os valores de ambos índices foram similares em magnitude (Figura 5a).

\subsubsection{Funções de resposta à temperatura do ar para o sub- período florescimento feminino-maturidade fisiológica}

De acordo com Dwyer et al. (1999), a equação para estimar FT (Equação 3) como um componente do ITG (Equação 2) tem o termo cúbico $\left(\mathrm{B}_{2}\right)$ igual a zero para o período de enchimento dos grãos. Neste estudo, os coeficientes empíricos que resultaram nos menores valores de RMSD entre os índices ITG e $\mathrm{TT}_{(8)}$ foram: 3,2225 para o $\mathrm{B}_{0} \mathrm{e}$ 0,021 para o $\mathrm{B}_{1}$. Utilizando-se esses coeficientes para estimar o ITG para o período reprodutivo, desde o florescimento feminino até a maturidade fisiológica, foi encontrada uma curva de resposta à temperatura do ar pouco acentuada, para valores de temperatura entre 0 e $12{ }^{\circ} \mathrm{C}$. Por outro lado, acima de $12{ }^{\circ} \mathrm{C}$ houve um incremento significativo na taxa de desenvolvimento, como mostra a Figura 4b. A análise de regressão entre essas duas variáveis (Figura 5b) confirma a relação entre elas, com o coeficiente angular da reta da regressão igual a 0,92 , valor estatisticamente diferente de zero, mostrando que existe relação positiva entre as variáveis. Além disso, o coeficiente linear foi estatisticamente diferente de zero e o coeficiente de determinação foi elevado $(0,95)$. 

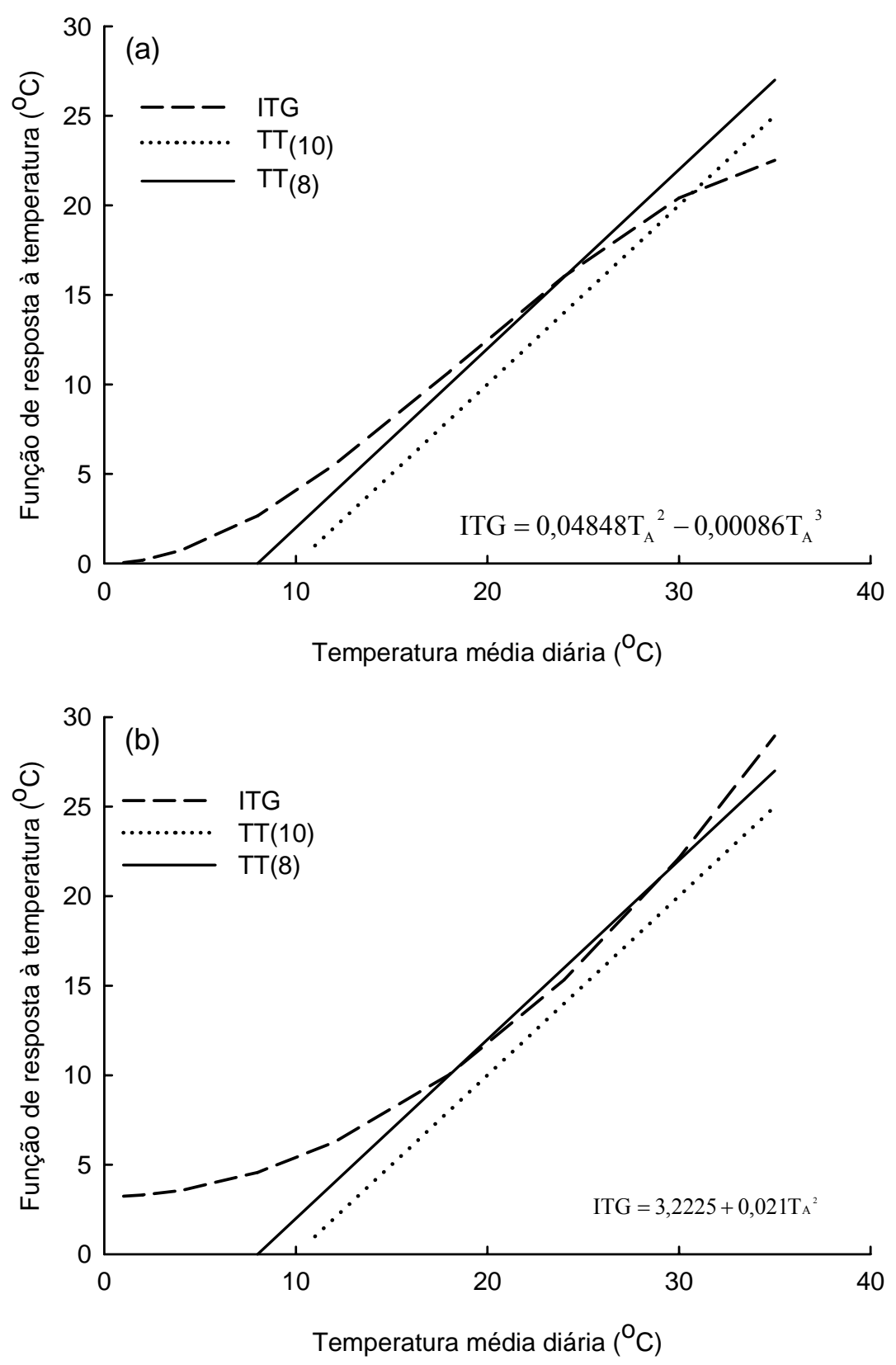

Figura 4 - Função de resposta à temperatura do ar apresentada pelos índices biometeorológicos ITG modificado, $\mathrm{TT}_{(10)}$ e $\mathrm{TT}_{(8)}$ para os sub-períodos semeadura- florescimento feminino (a) e florescimento femininomaturidade fisiológica (b). 

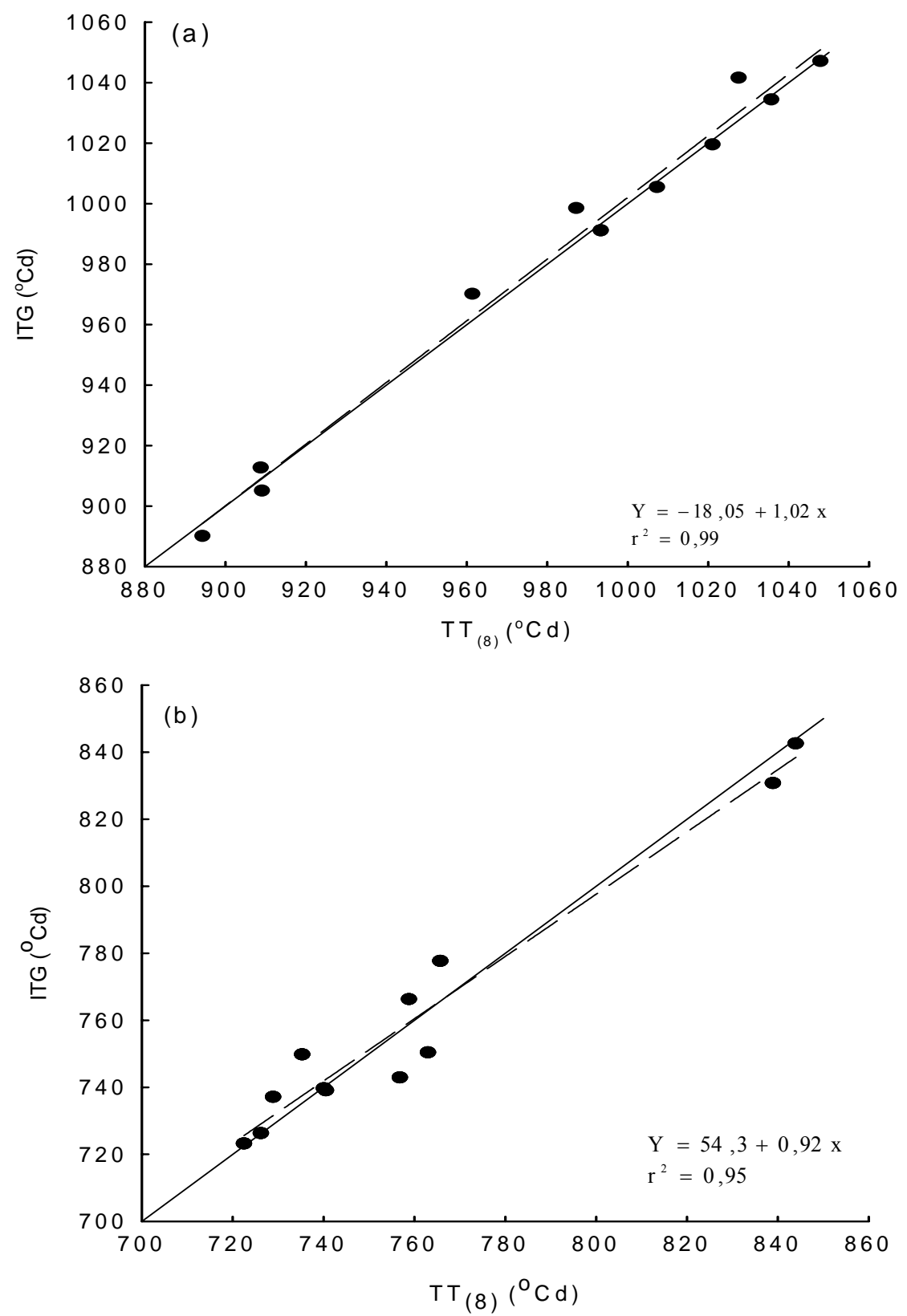

Figura 5 - Relação entre a soma térmica dada pelos índices ITG modificado e $\mathrm{TT}_{(8)}$ para os sub-períodos semeadura-florescimento feminino (a) e florescimento feminino-maturidade fisiológica (b), para quatro híbridos de milho semeados na "safrinha” em Piracicaba, Estado de São Paulo, Brasil. 


\subsubsection{Comparação dos índices biometeorológicos para o sub- período semeadura-florescimento feminino}

Os valores acumulados dos três índices biometeorológicos, baseados no tempo térmico, ITG, $\mathrm{TT}_{(10)}$ e $\mathrm{TT}_{(8)}$, e a duração, expressa em dias, do sub-período semeaduraflorescimento feminino são apresentados na Tabela 3.

A média do $\mathrm{TT}_{(10)}$ desde a semeadura até o florescimento variou entre $792,1{ }^{\circ} \mathrm{Cd}$, para o híbrido de ciclo super-precoce AG9010, e 903,1 ${ }^{\circ} \mathrm{Cd}$, para o híbrido de ciclo normal DKB 333B. Valores intermédiários foram encontrados para os outros dois híbridos de ciclo curto, DAS CO32 e Exceler. O índice $\mathrm{TT}_{(10)}$ para determinar a data de florescimento feminino resultou em elevados valores de desvio padrão, e em geral, com maiores valores de $\mathrm{CV}$ do que para os índices $\mathrm{TT}_{(8)}$ e ITG modificado. O híbrido AG9010 teve o menor valor de CV (0,82\%) para o índice $\mathrm{TT}_{(10)}$ para predizer o subperíodo semeadura-florescimento feminino. Esse híbrido tem um padrão de crescimento particular e sua principal característica é a sua precocidade.

A média da soma térmica pelo índice $\mathrm{TT}_{(8)}$ variou de $904,1{ }^{\circ} \mathrm{Cd}$, para o híbrido AG9010, a $1037,1{ }^{\circ} \mathrm{Cd}$, para o híbrido DKB 333B. Para o ITG modificado, a média foi $902,7{ }^{\circ} \mathrm{Cd}$, para o híbrido AG9010, e $1041,1{ }^{\circ} \mathrm{Cd}$, para o híbrido DKB 333B, valores similares àqueles obtidos com o índice $\mathrm{TT}_{(8)}$. $\mathrm{O}$ índice ITG modificado resultou nos menores valores de CV para os híbridos DKB 333B (0,61\%), DAS CO32 (1,06\%) e Exceler $(1,23 \%)$ e o maior valor de CV para o híbrido super-precoce AG9010 (1,27\%) do que os índices $\mathrm{TT}_{(8)}$ e $\mathrm{TT}_{(10)}($ Tabela 3$)$.

Em resumo, analisando-se a média dos CVs obtidos pelos três índices para predizer o sub-período semeadura-florescimento feminino, o índice ITG modificado resultou no menor valor de $\mathrm{CV}, 1,04 \%$, enquanto que o índice $\mathrm{TT}_{(10)}$ teve o maior deles $(2,01 \%)$ e o índice $\mathrm{TT}_{(8)}$ um valor intermédio $(1,37 \%)$.

A duração em dias observada desde a semeadura ao florescimento feminino para o híbrido de ciclo normal variou entre 63,5 e 71,7 dias, enquanto que para o híbrido super-precoce AG9010, a duração desse sub-período esteve entre 53,5 e 58,7 dias.

A duração do sub-período semeadura-florescimento feminino para o ano 2001 foi maior do que para o ano 2002, o que se deveu à diferença significativa de temperatura 
entre os dois anos de acordo com o teste de dados pareados (Freese, 1967 - resultados não apresentados). Na Figura 1b apresentam-se as temperaturas médias do ar para os anos em questão. Para o ano 2001, a temperatura média máxima dos primeiros 70 dias da estação de crescimento, período que abrange desde a semeadura até o florescimento de todos os híbridos, foi de $28,5{ }^{\circ} \mathrm{C}$ e a temperatura média mínima foi de $16,1^{\circ} \mathrm{C}$, enquanto que para o ano 2002 essas temperaturas foram de $29,7^{\circ} \mathrm{C}$ e $17,7^{\circ} \mathrm{C}$, respectivamente. As temperaturas mais elevadas durante a estação de crescimento do ano 2002 aceleraram o desenvolvimento da cultura, reduzindo assim o número de dias desde a semeadura até o florescimento feminino.

Para o experimento de sequeiro conduzido durante o ano 2002, a média de dias observados entre a semeadura e o florescimento feminino foi de 60 dias e sob condições irrigadas a média foi de 59,5 dias, não sendo essa diferença, portanto, significativa.

Os resultados sugerem que o uso dos índices biometeorológicos, baseados na temperatura do ar, para estimar o sub-período semeadura-florescimento é mais adequado do que só a duração em dias, já que tal duração teve um CV médio de 5,4\%, valor sensivelmente maior do que os apresentados pelos três índices estudados. 
Tabela 3 - Tempo térmico (TT), utilizando-se duas temperaturas base, índice térmico geral modificado (ITG) e a duração, em dias, do sub-período semeaduraflorescimento feminino, para quatro híbridos de milho semeados na "safrinha” em Piracicaba, SP, Brasil.

\begin{tabular}{|c|c|c|c|c|c|}
\hline Híbrido & Condição & $\mathbf{T T}_{(10)}$ & $\begin{array}{l}\mathrm{TT}_{(8)} \\
\left({ }^{0} \mathrm{C} . \mathrm{d}\right)\end{array}$ & ITG & $\begin{array}{c}\text { Observado } \\
\text { Dias }\end{array}$ \\
\hline \multirow[t]{6}{*}{ DKB 333B } & Irrigado, 2001 & 883,6 & 1027,6 & 1041,6 & 71,7 \\
\hline & Irrigado, 2002 & 907,7 & 1035,7 & 1034,4 & 63,5 \\
\hline & Sequeiro, 2002 & 917,9 & 1047,9 & 1047,1 & 64,0 \\
\hline & Média & 903,1 & 1037,1 & 1041,1 & 66,4 \\
\hline & Desvio padrão & 17,6 & 10,2 & 6,4 & 4,6 \\
\hline & CV (\%) & 1,95 & 0,99 & 0,61 & 6,90 \\
\hline \multirow[t]{6}{*}{ DAS CO32 } & Irrigado, 2001 & 851,2 & 987,2 & 998,5 & 67,3 \\
\hline & Irrigado, 2002 & 883,3 & 1007,3 & 1005,5 & 61,0 \\
\hline & Sequeiro, 2002 & 895,1 & 1021,1 & 1019,6 & 62,0 \\
\hline & Média & 876,5 & 1005,2 & 1007,9 & 63,4 \\
\hline & Desvio padrão & 22,7 & 17,0 & 10,7 & 3,4 \\
\hline & CV (\%) & 2,59 & 1,69 & 1,06 & 5,34 \\
\hline \multirow[t]{6}{*}{ EXCELER } & Irrigado, 2001 & 831,4 & 961,4 & 970,2 & 64,7 \\
\hline & Irrigado, 2002 & 871,3 & 993,3 & 991,2 & 60,0 \\
\hline & Sequeiro, 2002 & 871,3 & 993,3 & 991,2 & 60,0 \\
\hline & Média & 858,0 & 982,7 & 984,2 & 61,6 \\
\hline & Desvio padrão & 23,0 & 18,4 & 12,1 & 2,7 \\
\hline & CV (\%) & 2,69 & 1,88 & 1,23 & 4,38 \\
\hline \multirow[t]{6}{*}{ AG9010 } & Irrigado, 2001 & 790,8 & 908,8 & 912,7 & 58,7 \\
\hline & Irrigado, 2002 & 786,3 & 894,3 & 890,1 & 53,5 \\
\hline & Sequeiro, 2002 & 799,1 & 909,1 & 905,1 & 53,8 \\
\hline & Média & 792,1 & 904,1 & 902,7 & 55,3 \\
\hline & Desvio padrão & 6,5 & 8,5 & 11,5 & 2,9 \\
\hline & CV (\%) & 0,82 & 0,94 & 1,27 & 5,27 \\
\hline
\end{tabular}


A análise de regressão linear entre a duração do sub-período semeaduraflorescimento feminino e o tempo térmico dado pelos três índices biometeorológicos é apresentada na Figura 6a. O índice ITG modificado foi o mais preciso para predizer o sub-período semeadura-florescimento, em função de ter apresentado o maior coeficiente de determinação $\left(\mathrm{r}^{2}=0,63\right)$. Uma consistente variação ao redor da reta da regressão foi observada, indicando que o erro experimental e outras fontes de erro não consideradas pelo índice ITG modificado tiveram influência para a não obtenção de valores mais elevados do coeficiente de determinação. O índice ITG modificado apresentou o menor valor de intercepto $(473,3)$ e o maior valor de inclinação da reta $(8,28)$. Para os três índices biometeorológicos, ITG, $\mathrm{TT}_{(10)}$ e $\mathrm{TT}_{(8)}$, o teste estatístico t foi significativo, ao nível crítico de 0,05 , para a inclinação da reta da equação de regressão. Assim, a hipótese nula foi rejeitada, concluindo-se que houve uma relação positiva e significativa entre a duração em dias e as unidades térmicas estimadas pelos três índices. O intercepto também foi estatisticamente diferente de zero para os três índices. O menor valor de coeficiente de determinação foi encontrado para o $\operatorname{TT}_{(10)}\left(\mathrm{r}^{2}=0,37\right)$ com o menor coeficiente angular $(5,34)$. A análise do erro padrão da estimativa (SEE) mostrou que a variabilidade real sobre a reta de regressão foi menor para o ITG modificado $\left(34,7{ }^{\circ} \mathrm{Cd}\right)$ do que para os outros dois índices, $\operatorname{TT}_{(10)}\left(38,1{ }^{\circ} \mathrm{Cd}\right)$ e $\mathrm{TT}_{(8)}\left(38,5{ }^{\circ} \mathrm{Cd}\right)$. 

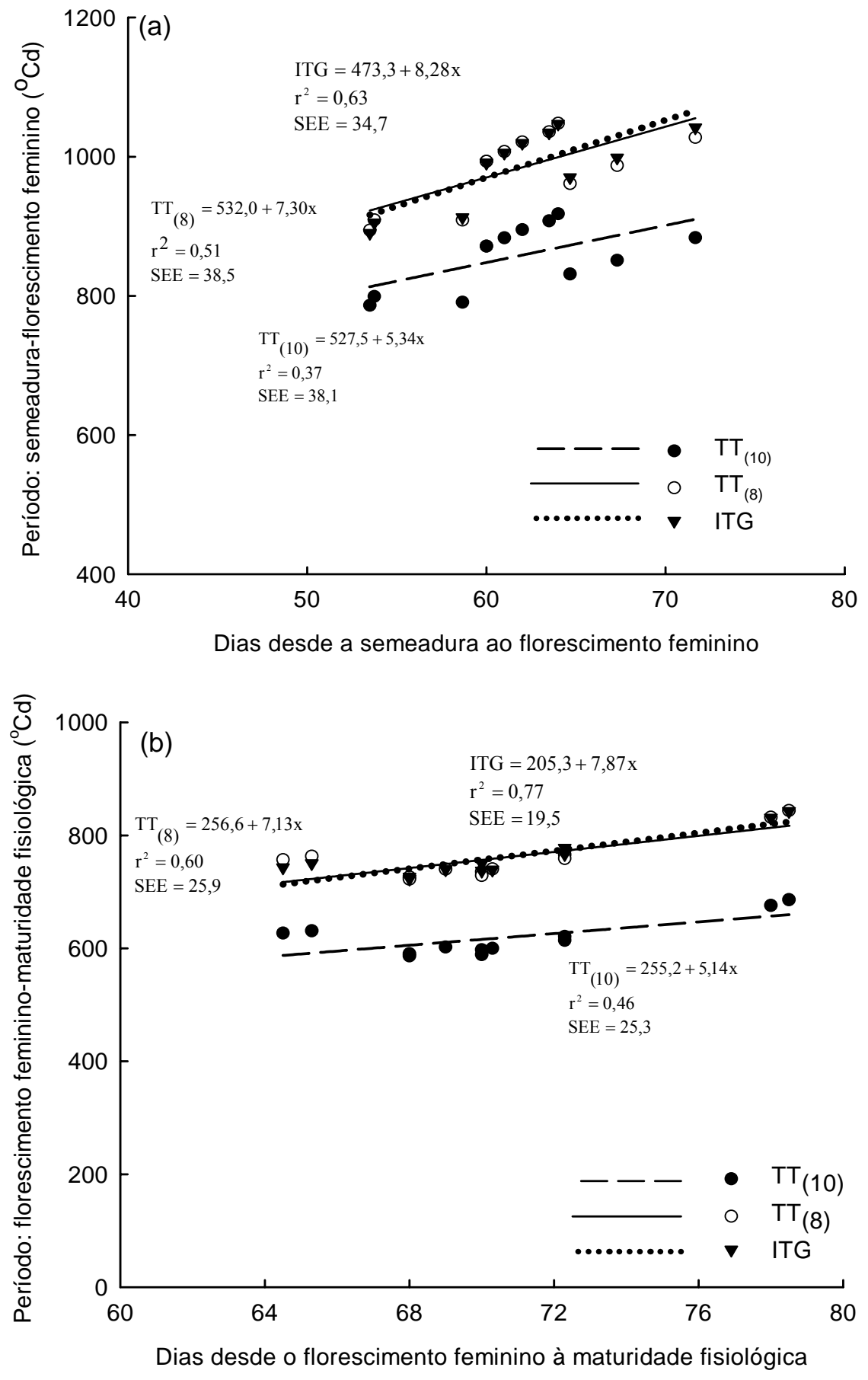

Figura 6 - Relação entre o tempo térmico obtido pelos índices biometeorológicos, $\mathrm{TT}_{(8)}$, $\mathrm{TT}_{(10)}$ e ITG modificado, e as durações dos sub-períodos semeaduraflorescimento feminino (a) e florescimento feminino-maturidade fisiológica (b). 


\subsubsection{Comparação dos índices biometeorológicos para o sub-período florescimento feminino-maturidade fisiológica}

A média de $\mathrm{TT}_{(10)}$ desde o florescimento feminino até a maturidade fisiológica variou entre $592,2{ }^{\circ} \mathrm{Cd}$, para o híbrido de ciclo curto DAS CO32, até $660,9{ }^{\circ} \mathrm{Cd}$, para o híbrido de ciclo normal DKB 333B, com valores intermediários para os outros dois híbridos: AG9010 (615,6 $\left.{ }^{\circ} \mathrm{Cd}\right)$ e Exceler $\left(604,5{ }^{\circ} \mathrm{Cd}\right)($ Tabela 4).

Para o índice $\mathrm{TT}_{(8)}$, o TT variou entre $729,7{ }^{\circ} \mathrm{Cd}$, para o híbrido DAS CO32, e $813,8{ }^{\circ} \mathrm{Cd}$, para o híbrido DKB 333B. Ao mesmo tempo, os valores do índice ITG modificado variaram entre $729,5{ }^{\circ} \mathrm{Cd}$, para o híbrido DAS CO32, e $817,0{ }^{\circ} \mathrm{Cd}$, para o híbrido DKB 333B. Os menores valores de $\mathrm{CV}(\%)$ obtidos com o índice ITG modificado para estimar a duração do sub-período florescimento feminino-maturidade fisiológica para os híbridos DKB 333B, DAS CO32 e AG9010 indica que tal índice é mais indicado do que o $\mathrm{TT}_{(8)}$ (Tabela 4). Somente para o híbrido Exceler, o coeficiente de variação do índice $\mathrm{TT}_{(10)}$, para o sub-período em questão, foi menor $(1,44 \%)$ do que outros .

Resumindo, o índice ITG modificado para os quatro híbridos estudados, teve menor CV médio $(2,01 \%)$ do que os índices $\mathrm{TT}_{(8)}(2,64 \%)$ e $\mathrm{TT}_{(10)}(2,91 \%)$.

A duração em dias observada para o sub-período florescimento femininomaturidade fisiológica variou entre 64,5 dias, para o híbrido super-precoce AG9010, e 78,5 dias, para o híbrido de ciclo normal DKB 333B. A duração em dias da fase reprodutiva teve um $\mathrm{CV}$ médio de 3,3\% para os quatro híbridos, valor menor do que o obtido para o sub-período semeadura-florescimento feminino, que foi de 5,4\%. Esses resultados estão em concordância com observações apresentadas previamente, em que o sub-período florescimento feminino-maturidade fisiológica, em dias, varia menos do que o sub-período semeadura-florescimento feminino. Por esse motivo, os estudos de resposta à temperatura, tem se concentrado majoritariamente na fase vegetativa. $\mathrm{O}$ índice clássico para estimar o tempo térmico tem sido menos útil para o período reprodutivo pois o TT requerido para atingir a maturidade em genótipos específicos tem mostrado ser variável com as condições ambientais (Plett, 1992). 
Tabela 4 - Tempo térmico (TT), utilizando-se duas temperaturas base, índice térmico geral modificado (ITG) e a duração, em dias, do sub-período florescimento feminino-maturidade fisiológica, para quatro híbridos de milho semeados na "safrinha" em Piracicaba, SP, Brasil.

\begin{tabular}{|c|c|c|c|c|c|}
\hline Híbrido & Condição & $\mathbf{T T}_{(10)}$ & $\begin{array}{l}\mathrm{TT}_{(8)} \\
\left({ }^{0} \mathrm{Cd}\right)\end{array}$ & ITG & $\begin{array}{c}\text { Observado } \\
\text { Dias }\end{array}$ \\
\hline \multirow[t]{6}{*}{ DKB 333B } & Irrigado, 2001 & 621,0 & 765,7 & 777,7 & 72,3 \\
\hline & Irrigado, 2002 & 685,9 & 844,0 & 842,6 & 78,5 \\
\hline & Sequeiro, 2002 & 675,8 & 831,8 & 830,8 & 78,0 \\
\hline & Média & 660,9 & 813,8 & 817,0 & 76,3 \\
\hline & Desvio padrão & 35,0 & 42,1 & 34,6 & 3,4 \\
\hline & CV (\%) & 5,29 & 5,18 & 4,23 & 4,52 \\
\hline \multirow[t]{6}{*}{ DAS CO32 } & Irrigado, 2001 & 599,8 & 740,5 & 739,1 & 70,3 \\
\hline & Irrigado, 2002 & 590,2 & 726,2 & 726,3 & 68,0 \\
\hline & Sequeiro, 2002 & 586,5 & 722,5 & 723,2 & 68,0 \\
\hline & Média & 592,2 & 729,7 & 729,5 & 68,8 \\
\hline & Desvio padrão & 6,9 & 9,5 & 8,4 & 1,3 \\
\hline & CV (\%) & 1,16 & 1,30 & 1,15 & 1,93 \\
\hline \multirow[t]{6}{*}{ EXCELER } & Irrigado, 2001 & 614,2 & 758,8 & 766,3 & 72,3 \\
\hline & Irrigado, 2002 & 602,1 & 740,1 & 739,7 & 69,0 \\
\hline & Sequeiro, 2002 & 597,3 & 735,3 & 749,8 & 70,0 \\
\hline & Média & 604,5 & 744,7 & 751,9 & 70,4 \\
\hline & Desvio padrão & 8,7 & 12,4 & 13,4 & 1,7 \\
\hline & CV (\%) & 1,44 & 1,67 & 1,79 & 2,40 \\
\hline \multirow[t]{6}{*}{ AG9010 } & Irrigado, 2001 & 588,9 & 728,9 & 737,1 & 70,0 \\
\hline & Irrigado, 2002 & 626,8 & 756,8 & 742,9 & 64,5 \\
\hline & Sequeiro, 2002 & 631,0 & 763,0 & 750,4 & 65,3 \\
\hline & Média & 615,6 & 749,6 & 743,5 & 66,6 \\
\hline & Desvio padrão & 23,2 & 18,2 & 6,6 & 3,0 \\
\hline & CV (\%) & 3,77 & 2,43 & 0,89 & 4,46 \\
\hline
\end{tabular}


Normalmente, o conceito de TT superestima as unidades térmicas requeridas para o enchimento dos grãos (Dwyer et al., 1996; Roth e Yocum, 1997). No entanto, os índices biometeorológicos avaliados, principalmente o índice ITG modificado, tiveram um menor $\mathrm{CV}(\%)$ do que a simples observação do número de dias para os quatro híbridos analisados.

O índice ITG modificado para caracterização do sub-período florescimento feminino-maturidade fisiológica teve o maior coeficiente de determinação em função do número de dias $\left(\mathrm{r}^{2}=0,77\right)$ e o menor valor do erro padrão da estimativa $\left(19,5{ }^{\circ} \mathrm{Cd}\right)$, mostrando ser um índice adequado para predição desta fase (Figura 6b). O menor coeficiente de determinação $(0,46)$ foi encontrado para o índice $\mathrm{TT}_{(10)}$, o que também foi observado na fase vegetativa. Os três índices utilizados para caracterizar a fenologia do milho "safrinha" apresentaram intercepto e inclinação da reta da equação de regressão linear estatisticamente diferente de zero. A declividade diferente de zero sugere que houve uma relação positiva e significativa entre a duração em dias da fase reprodutiva e o tempo térmico estimado pelos três índices. Os índices $\mathrm{TT}_{(8)}$ e $\mathrm{TT}_{(10)}$ apresentaram os maiores valores do erro padrão da estimativa, respectivamente $25,9{ }^{\circ} \mathrm{Cd}$ e $25,3{ }^{\circ} \mathrm{Cd}$.

\subsubsection{Avaliação dos indices biometeorológicos com dados independentes}

Para os três índices estudados, em média, o híbrido DKB 333B, de ciclo normal, necessitou maior tempo térmico para atingir o florescimento do que os híbridos de ciclo curto, Exceler e DAS CO32 (Tabela 5). Para os índices ITG modificado e $\mathrm{TT}_{(8)}$, a diferença média entre tempo térmico desde a semeadura até o florescimento para ambos os híbridos, de ciclo normal e curto, foi de aproximadamente $100{ }^{\circ} \mathrm{Cd}$. Em todos os cinco locais do Estado de São Paulo analisados foi encontrada variação entre o tempo térmico estimado pelos três índices, $\mathrm{TT}_{(10)}, \mathrm{TT}_{(8)}$ e ITG modificado, desde a semeadura até o florescimento, para os três híbridos. Por exemplo, para o híbrido Exceler, utilizando o índice $\mathrm{TT}_{(10)}$, foram encontrados $711,6{ }^{\circ} \mathrm{Cd}$ para a localidade de Capão Bonito e $894,2{ }^{\circ} \mathrm{Cd}$ para a localidade de Pedrinhas. Similarmente, para dois híbridos, DKB 333B e DAS CO32, o menor valor de tempo térmico com os índices $\mathrm{TT}_{(8)}$ e ITG 
modificado foram encontrados em Capão Bonito e os maiores em Pedrinhas. Valores intermediários foram encontrados para os outros locais, Ribeirão Preto, Tarumã e Guaíra. A análise de regressão entre a temperatura média do ar do sub-período semeadura-florescimento e o tempo térmico estimado com o índice ITG modificado, não evidenciou relação entre essas duas variáveis. Talvez parte dessa variação poderia ser explicada por outros fatores que influenciaram o desenvolvimento do milho, como os estresses hídrico e nutricional, que não foram apresentados nos dados de competição de cultivares nos cinco locais estudados.

A duração em dias desde a semeadura até o florescimento variou entre 54 dias, para o híbrido Exceler cultivado em Guaíra durante o ano 1998, e 88 dias, para o híbrido DKB 333B cultivado em Capão Bonito durante o ano 2000.

Os resultados do análise do coeficiente de variação indicaram que os valores mais baixos do $\mathrm{CV}(\%)$ foram obtidos com o índice ITG modificado (Tabela 5). O CV médio, para os três híbridos, foi de 7,5\% para $\mathrm{TT}_{(10)}, 6,3 \%$ para $\mathrm{TT}_{(8)}$ e 5,2\% para o índice ITG modificado. O CV para os dias observados desde a semeadura até o florescimento teve o maior valor nos cinco locais $(12,4 \%)$. Ressalta-se que o CV obtido para cada híbrido nos diferentes locais foi maior do que o obtido nos três experimentos em Piracicaba, o que se deve, possivelmente, ao fato de que nos ensaios regionais de competição de cultivares a avaliação da fenologia não é feita na escala diária. Além disso, outros fatores que influenciam o desenvolvimento do milho não foram reportados. 
Tabela 5 - Tempo térmico (TT), utilizando-se duas temperaturas base, índice térmico geral modificado (ITG) e duração, em dias, do sub-período semeaduraflorescimento em diferentes locais do Estado de São Paulo, Brasil, para três híbridos de milho semeados na "safrinha".

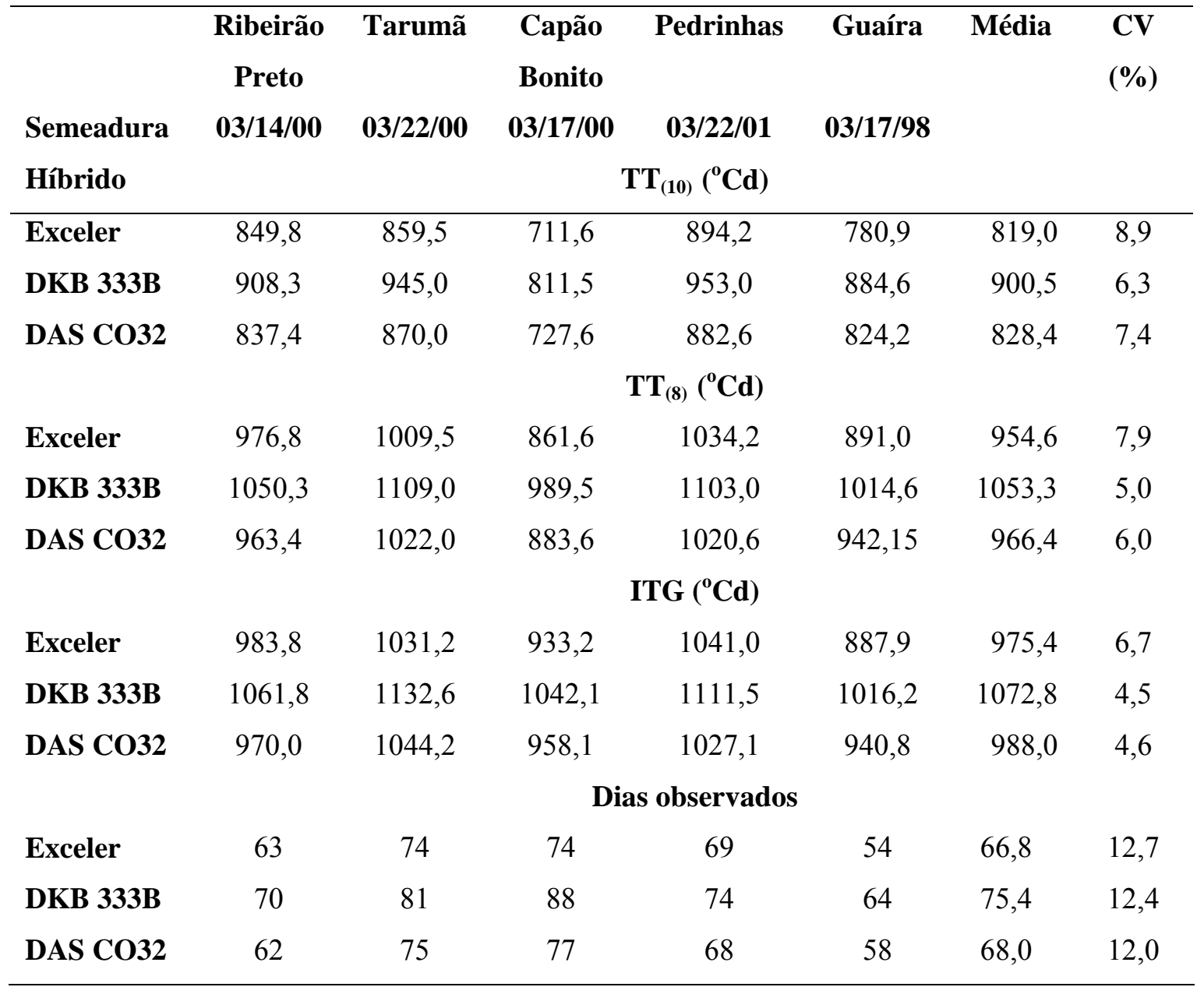

A análise de regressão entre os valores obtidos com os diferentes índices biometeorológicos e a duração do sub-período semeadura-florescimento, em dias, resultou em maior coeficiente de determinação para o índice ITG modificado $\left(\mathrm{r}^{2}=0,37\right)$ em comparação aos índices $\operatorname{TT}_{(8)}\left(\mathrm{r}^{2}=0,10\right)$ e $\mathrm{TT}_{(10)}\left(\mathrm{r}^{2}=0,006\right)$, como pode ser visto na Figura 7. A inclinação da reta da equação de regressão foi estatisticamente diferente de zero somente para o índice ITG modificado, indicando que variações nos dias observados estiveram relacionadas com variações no tempo térmico. As equações de 
regressão tiveram interceptos estatisticamente diferentes de zero para os três índices estudados. O menor valor do desvio do erro da estimativa $\left(54,9{ }^{\circ} \mathrm{Cd}\right)$ foi obtido com o índice ITG modificado.

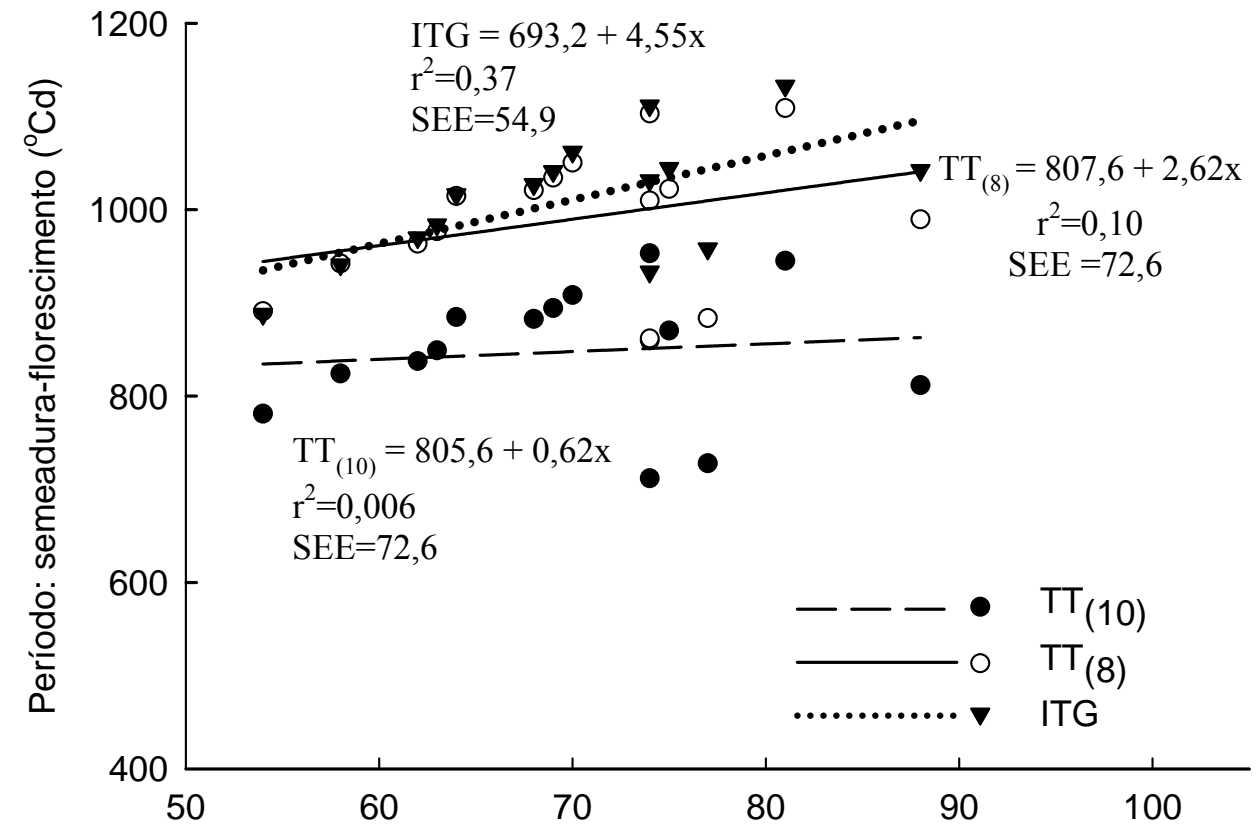

Dias desde a semeadura ao florescimento

Figura 7 - Relação entre o tempo térmico obtido pelos índices $\mathrm{TT}_{(8)}, \mathrm{TT}_{(10)}$ e ITG modificado, e o número de dias do sub-período semeadura-florescimento, considerando-se cinco diferentes locais do Estado de São Paulo, Brasil.

\subsection{Conclusões}

Com base nas análises conduzidas neste estudo foi encontrado que o filotermo da cultura do milho semeado na "safrinha" no Estado de São Paulo foi da ordem de $50{ }^{\circ} \mathrm{Cd}$ até aproximadamente a aparição da $12^{\mathrm{a}}$ folha, passando a decrescer a partir daí. $\mathrm{O}$ valor de filotermo mostrou estar positivamente correlacionado com a temperatura do ar. $\mathrm{O}$ número final de folhas dos quatro híbridos de milho utilizados neste estudo esteve altamente correlacionado $(\mathrm{r}=0,98)$ com a duração do sub-período semeaduraflorescimento feminino. O índice ITG modificado para estimativa de datas de 
florescimento feminino e maturidade fisiológica resultou em menores valores de CV do que os índices $\mathrm{TT}_{(8)}$ e $\mathrm{TT}_{(10)}$. Além disso, a análise de regressão resultou em mais altos coeficientes de determinação para a relação entre o tempo térmico obtido pelo índice ITG modificado e a duração em dias de ambos sub-períodos estudados, semeaduraflorescimento feminino e florescimento feminino-maturidade fisiológica. Ao se analisar a duração em dias para os dois sub-períodos estudados nos quatro híbridos, foi encontrado uma menor variação $(\mathrm{CV} \%)$ para a fase reprodutiva do que para a fase vegetativa. O índice ITG modificado é um índice promissor para a caracterização da fenologia do milho semeado na "safrinha" devido à sua maior precisão em diferentes condições ambientais do Estado de São Paulo, Brasil. No entanto, mais estudos com outros híbridos de milho são necessários para se confirmar os avanços de se estimar os principais estágios fenológicos do milho baseando-se no índice ITG modificado. 


\section{ANÁLISE DE CRESCIMENTO DO MILHO (ZEA MAYS L.) "SAFRINHA" CULTIVADO EM CONDIÇÕES DE SEQUEIRO E IRRIGADAS}

\section{Resumo}

$\mathrm{Na}$ última década, a área de milho "safrinha" tem se incrementado nas regiões Centro-Oeste e Sudeste do Brasil. A cultura de milho "safrinha" normalmente é semeada entre os meses de janeiro e abril, o que determina um alto risco de quebra de rendimento devido principalmente à alta variabilidade de precipitação e à probabilidade de ocorrência de geadas nos estádios reprodutivos. Baixos rendimentos também podem resultar do uso de cultivares não adaptados as condições de crescimento da cultura, desde que o material genético disponível usualmente provêm de seleções para o período tradicional de cultivo (setembro a dezembro). As vantagens de se identificar e usar os melhores cultivares adaptados às condições da "safrinha" são cruciais para a obtenção de rendimentos mais elevados e estáveis. Assim, os objetivos deste trabalho foram estudar o crescimento e desenvolvimento do milho, o rendimento e seus componentes e a eficiência de uso da água em quatro híbridos de milho de diferentes ciclos, semeados na época da "safrinha" em condições de irrigação e de sequeiro. Três experimentos foram conduzidos na área experimental do Departamento de Produção Vegetal da ESALQUSP, em Piracicaba, Estado de São Paulo, durante os anos 2001 e 2002. O delineamento experimental foi de blocos ao acaso, envolvendo quatro híbridos (AG9010, DAS CO32, Exceler e DKB 333B) com 3 repetições no ano 2001 e 4 repetições no ano 2002. A semeadura foi realizada em 15 de março de 2001 e 13 de março de 2002, com 0,80 m de espaçamento entre linhas e com uma densidade de 50.000 plantas por hectare. Foram realizadas medidas de área foliar, altura de planta e acúmulo de matéria seca a cada 18 
dias aproximadamente. Os resultados indicaram que limitações de água durante o período vegetativo determinaram, em geral, menores valores de índice de área foliar (IAF), altura de planta e acúmulo de matéria seca. Sob condições de sequeiro, o conteúdo de água no solo foi reduzido até as camadas mais profundas do solo, sendo um indicador de que a limitação de água provocou um aumento na extensão das raízes. A eficiência de uso de água variou entre $14,5 \mathrm{~kg} \mathrm{ha}^{-1} \mathrm{~mm}^{-1}$ sob condições de sequeiro e $16,9 \mathrm{~kg} \mathrm{ha}{ }^{-1} \mathrm{~mm}^{-1}$ sob condições de irrigação durante o ano 2001. A quebra de rendimento sob condições de sequeiro foi afetada pelo genótipo. Para o híbrido DKB $333 \mathrm{~B}$, de ciclo normal, a quebra foi de $25,6 \%$ enquanto que para o híbrido Exceler a quebra foi de $8,4 \%$. Os híbridos estudados responderam de diferente forma às limitações de água no solo, mostrando que existe considerável variabilidade nas suas características de crescimento.

\section{Summary}

In last decade, the area sown with maize off-season (named "Safrinha") has increased in Center-Western and South-Eastern regions of Brazil. Growing maize during this season, in which sowing is done from January to April, imposes some risks, mainly due to the high variability of precipitation and the probability of frost during reproduction phases, that impact crop yield. Low yields and high-risk of production can also be result of the use of non-adapted cultivars to the environment conditions during the growing season, since the available genetic material is usually obtained from selections for the traditional period of the crop (from September to December). The advantages of identifying and using the best maize hybrids adapted to the off-season are crucial to obtain highest and stable yields under rainfed conditions in subtropical environments. The objectives of this work were to evaluate crop growth and development, yield and its components, and to study the water use efficiency in four maize hybrids of different cycles grown off-season in a subtropical environment under rainfed and irrigated conditions. Three experiments were carried out at the experimental area of the Department of Crop Production of the University of São Paulo, in Piracicaba, 
State of São Paulo, Brazil, during 2001 and 2002. A completely randomized design with four hybrids (AG9010, DAS CO32, Exceler and DKB 333B) and 3 replications in 2001 and 4 replications in 2002 was used. Maize was sown on March 15 $5^{\text {th }}, 2001$, and on March $13^{\text {th }}, 2002$, with $0.80 \mathrm{~m}$ rows space and plant density of 50,000 plants $\mathrm{ha}^{-1}$. Determinations of leaf area index (LAI), plant height and dry matter were done each 18 days approximately. Results indicated that water limitations during vegetative phase determined, in general, lowest values of LAI, plant height and dry matter accumulation. Under rainfed conditions, soil water content in deep layers was reduced, suggesting that a response to water limitations was the extension of the roots to deep layers. Water use

efficiency varied in average, from $14.5 \mathrm{~kg} \mathrm{ha}^{-1} \mathrm{~mm}^{-1}$ under rainfed conditions to $16.9 \mathrm{~kg}$ $\mathrm{ha}^{-1} \mathrm{~mm}^{-1}$ under irrigated conditions of year 2001. Yield reductions under rainfed conditions were affected by the genotype. For the hybrid DKB 333B, of normal maturity classification, the yield reduction was $25.6 \%$ while the short maturity class hybrid, Exceler, had a reduction of $8.4 \%$. Different studied hybrids responded in a different way to soil water limitations, showing that considerable variation exists in maize in response to phenology and growth characteristics.

\subsection{Introdução}

Nos últimos anos, o milho (Zea mays L.) tem se tornado numa das principais alternativas de culturas durante o outono e inverno em regiões subtropicais do CentroOeste e do Sudeste do Brasil. Durante esse período do ano é comum a ocorrência de déficits hídricos e de temperaturas sub-ótimas que se traduzem em reduções do rendimento potencial. Em regiões subtropicais do Brasil, o milho "safrinha" é cultivado em condições de sequeiro, o que explica em parte a alta variabilidade nos rendimentos observados (Caramori et al., 1999). Nestes ambientes subtropicais, baixos rendimentos e elevado risco na produção do milho "safrinha" podem estar associados ao uso de materiais genéticos não adaptados as condições ambientais da estação de crescimento, já que as cultivares utilizadas são usualmente obtidas de seleções realizadas durante o período tradicional de cultivo, de setembro a dezembro (Quiessi et al., 1999). Kamara et 
al. (2003) encontraram que alguns genótipos selecionados para alto rendimento sob condições de crescimento normal também tinham adequado acúmulo de matéria seca e alocavam maior proporção de assimilados para os grãos sob condições de estresse de água. No entanto, Fisher et al. (1989) recomendaram que genótipos melhorados que tem melhor performance sob condições de deficiência hídrica sejam recomendados em áreas propensas à ocorrência de veranicos. Também, tem sido argumentado que as cultivares de milho de baixa altura tendem a ser mais tolerantes à deficiência hídrica do que as cultivares de maior altura.

O uso de cultivares de curta duração (ciclo curto) tem se incrementado em regiões com baixa disponibilidade de água, onde há necessidade de irrigação ou quando é desejável uma colheita antecipada (Howell et al., 1998). Por exemplo, em algumas regiões, o clima frio e úmido pode atrasar a semeadura, limitando assim o número de dias até a colheita, forçando os agricultores a considerar o uso de cultivares de ciclo curto. Em algumas regiões temperadas, investigações de longo período tem mostrado que cultivares adaptadas para toda a estação de crescimento normalmente oferecem os melhores rendimentos (Iragavarapu, 1999).

Uma das melhores formas de se incrementar e estabilizar a produção de uma cultura é mediante a aplicação de irrigação complementar. No entanto, em razão dos recursos hídricos estarem entrando em declínio em muitas regiões subtropicais, devido à competição com os setores doméstico e industrial, os estudos sobre a eficiência de uso da água e o manejo da água nas principais culturas vem se tornando cada vez mais importantes. Por exemplo, Howell et al. (1995) relatou valores de eficiência de uso da água para o milho irrigado variando entre $1,27 \mathrm{~kg} \mathrm{~m}^{-3}$ e $1,35 \mathrm{~kg} \mathrm{~m}^{-3}$.

Nos trópicos semi-áridos, Abrecht e Carberry (1993) concluíram que déficits hídricos durante o crescimento vegetativo do milho resultaram em marcante redução na altura das plantas e no acúmulo de biomassa e em atraso no desenvolvimento, que não estaria associado com a diminuição do rendimento potencial. No entanto, Musick e Dusek (1980) e Tolk et al. (1998) verificaram que em algumas regiões o uso da subirrigação deveria ser realizado com precaução devido à sensibilidade das plantas do milho à deficiência hídrica e à alta demanda evaporativa, que poderia contrabalançar os 
efeitos benéficos de uma irrigação moderada. A maioria dos estudos indicam que déficits hídricos durante o período vegetativo reduzem o índice de área foliar (Muchow e Carberry, 1989; NeSmith e Ritchie, 1992a), a elongação dos entre nós (Novoa e Loomis, 1981) e o peso de folhas e caules (Eck, 1984). Todavia, essa redução na área foliar poderia ser uma estratégia de adaptação das plantas de milho quando expostas à condições de estresse hídrico durante o período vegetativo, para assim diminuir a transpiração (Pandey et al., 2000). De acordo com Kiniry e Ritchie (1985), o período mais crítico para determinação do rendimento para plantas sob estresse é o de 2 semanas antes e após ao florescimento feminino. $\mathrm{O}$ estresse de água antes do florescimento causa falhas no desenvolvimento da espiga, enquanto que depois da polinização limita o número de grãos (Harder et al., 1982). A máxima redução do número de grãos, de acordo com Greenwood (1976), Frey (1982) e Fapohunda e Hussain (1990) resultou do estresse hídrico que ocorreu no florescimento feminino e nos primeiros estágios do enchimento dos grãos. Grant et al. (1989) encontraram que estresse de água prévio ao florescimento feminino não diminuiu o número de grãos por espiga. Porém, durante as fases iniciais do enchimento dos grãos o estresse hídrico resultou em reduções significativas do número de grãos. Andrade et al. (1999) verificaram que limitação da partição da matéria seca aos tecidos reprodutivos durante o período crítico de emissão da flor feminina, resultou no estabelecimento de baixo número de grãos.

Para um genótipo específico, o número de grãos estabelecido é mais crítico e mais afetado pelas condições do ambiente do que o número de espiguetas diferenciadas (Uhart e Andrade, 1995, Otegui, 1997). Pandey et al. (2001) encontraram que o rendimento em grãos esteve associado primeiramente com o número de grãos por metro quadrado e em segundo lugar com a massa do grão, quando deficiências hídricas foram impostas durante as fases vegetativa e reprodutiva. Existem poucas informações a respeito da cultura de milho "safrinha", em condições de sequeiro, nas diferentes regiões do Brasil, porém, as vantagens de se identificar e utilizar os híbridos melhor adaptados a essas condições são cruciais para a obtenção de rendimentos elevados e estáveis.

De acordo com o que foi previamente relatado, o principal objetivo do presente estudo foi o de avaliar o crescimento de quatro cultivares de milho de diferentes 
durações de ciclo até o florescimento, semeados na época da "safrinha", em condições de sequeiro e de irrigação. Os objetivos específicos incluíram: a) estudar a altura, o índice de área foliar (IAF) e o acúmulo de matéria seca pelas plantas em função do tempo térmico; b) analisar o efeito do estresse de água no desenvolvimento e rendimento do milho; e c) estudar a eficiência de uso de água na cultura de milho em condições de irrigação e de sequeiro.

\subsection{Materiais e métodos}

\subsubsection{Experimentos de campo}

Três experimentos com quatro híbridos de milho foram conduzidos na "Escola Superior de Agricultura Luiz de Queiroz", Universidade de São Paulo, em Piracicaba ( $22^{\circ} 43^{\prime}$ latitude Sul, $47^{\circ} 25^{\prime}$ longitude Oeste, $580 \mathrm{~m}$ acima do nível do mar), Estado de São Paulo, Brasil, durante os anos 2001 e 2002. O clima da região, de acordo com a classificação de Köppen, é Cwa: subtropical com verão chuvoso e inverno seco. O solo da área experimental é classificado como Terra Roxa Estruturada.

Um experimento foi conduzido em 2001 sob condições irrigadas e dois experimentos foram conduzidos em 2002, um sob condições de sequeiro e outro sob condições irrigadas. Todos os experimentos tiveram delineamento de blocos completos ao acaso com três repetições no ano 2001 e quatro repetições no ano 2002. Os híbridos usados neste estudo foram: AG9010 (ciclo super-precoce), DAS CO32 e Exceler (ciclo curto) e DKB 333B (ciclo normal). As épocas de semeadura foram: 15 de março, para o experimento conduzido no ano 2001, e 13 de março, para os experimentos do ano 2002. O tamanho das parcelas foi de 4 fileiras com espaçamento de $0,8 \mathrm{~m}$ e $20 \mathrm{~m}$ de comprimento. Após a germinação deixou-se até 4 plantas por metro linear. Todos os experimentos foram fertilizados com NPK, fórmula 8-28-16 (380 kg ha ${ }^{-1}$ para o experimentos irrigados e $250 \mathrm{~kg} \mathrm{ha}^{-1}$ para os experimentos de sequeiro) e com uréia (108 $\mathrm{kg} \mathrm{ha}^{-1}$ aplicado no sulco) no estágio V5-V6. Adicionalmente, os experimentos irrigados foram fertilizados com uréia (108 $\mathrm{kg} \mathrm{ha}^{-1}$ aplicado no sulco) no estágio V10. As pragas e ervas daninhas foram controladas seguindo-se as recomendações para a cultura. A água 
foi aplicada nos experimentos irrigados via pivô central em quantidades e freqüências visando evitar estresse hídrico. As irrigações foram baseadas na evapotranspiração da cultura estimada pelo método do tanque classe A (Allen et al., 1998).

A área das folhas e a altura das plantas foram medidas a cada 18 dias, aproximadamente, em três plantas por parcela nos três experimentos. A área foliar foi estimada pelo produto entre o comprimento e a largura máxima de cada folha e posteriormente, o valor total foi multiplicado por 0,75 , conforme o procedimento descrito por McKee (1964). A matéria seca aérea foi medida aproximadamente a cada 18 dias começando-se aos 21 dias após a semeadura até a colheita, amostrando-se 1 metro linear de plantas das fileiras centrais das parcelas. A colheita foi realizada manualmente em 16 metros lineares em duas fileiras centrais das parcelas, nos quais foram contados o número de espigas e de plantas. O número de espigas por planta foi calculado como o número total de espigas divido pelo número de plantas colhidas. As espigas colhidas de cada parcela foram descascadas e a porcentagem de umidade foi determinada em laboratório. Foram selecionadas 12 espigas em cada parcela para se contabilizar o número de grãos por espiga. $\mathrm{O}$ rendimento foi corrigido a $0 \%$ de umidade. $\mathrm{O}$ índice de colheita foi estimado dividindo-se a massa de grãos pela massa da matéria seca da parte aérea.

\subsubsection{Dados de clima e solo}

A temperatura máxima, mínima e média do ar, a precipitação, a radiação solar e a velocidade do vento foram obtidas pela estação meteorológica automática da Escola Superior de Agricultura "Luiz de Queiroz", da Universidade de São Paulo, situada a cerca de $1 \mathrm{~km}$ dos experimentos de campo. 
A análise do crescimento do milho foi expressa em termos de tempo térmico, o qual foi obtido da seguinte forma (equação 1):

$\mathrm{TT}_{8}=\sum_{\mathrm{j}=1}^{\mathrm{n}}\left(\frac{\mathrm{T} \max +\mathrm{T} \min }{2}\right)-\mathrm{Tb}$

em que $\mathrm{TT}_{8}=$ tempo térmico $\left({ }^{\circ} \mathrm{Cd}\right)$; Tmax $=$ temperatura máxima do ar; Tmin $=$ temperatura mínima do ar; $\mathrm{Tb}=$ temperatura base, abaixo da qual o crescimento e desenvolvimento se torna nulo, sendo assumido o valor de $8^{\circ} \mathrm{C}$ (Kiniry, 1991; Barbano et al., 2001; Birch et al., 2003), e n é o número de dias utilizados na soma térmica.

Para a estimativa da evapotranspiração de referência foi utilizada a equação de Penman-Monteith (Allen et al., 1998). A equação determina a evapotranspiração de uma superfície vegetal hipotética influenciada apenas pelo balanço vertical de energia (equação 2):

$E T_{0}=\frac{0.408 \Delta\left(R_{n}-G\right)+\gamma \frac{900}{T+273} u_{2}\left(e_{s}-e_{a}\right)}{\Delta+\gamma\left(1+0.34 u_{2}\right)}$

em que $\mathrm{ET}_{\mathrm{o}}=$ evapotranspiração de referência $\left(\mathrm{mm} \mathrm{dia}^{-1}\right) ; \mathrm{R}_{\mathrm{n}}=$ saldo de radiação na superfície da cultura $\left(\mathrm{MJ} \mathrm{m}^{-2} \mathrm{dia}^{-1}\right) ; \mathrm{G}=$ densidade de fluxo de calor no solo $\left(\mathrm{MJ} \mathrm{m}^{-2} \mathrm{dia}^{-}\right.$ $\left.{ }^{1}\right) ; \mathrm{T}=$ temperatura do ar a $2 \mathrm{~m}$ de altura $\left({ }^{\circ} \mathrm{C}\right) ; \mathrm{u}_{2}=$ velocidade do vento a $2 \mathrm{~m}$ de altura $\left(\mathrm{m} \mathrm{s}^{-1}\right) ; \mathrm{e}_{\mathrm{s}}=$ pressão de saturação $(\mathrm{kPa}) ; \mathrm{e}_{\mathrm{a}}=$ pressão atual de vapor $(\mathrm{kPa}) ; \mathrm{e}_{\mathrm{s}}-\mathrm{e}_{\mathrm{a}}=$ déficit de pressão de vapor $(\mathrm{kPa}) ; \Delta=$ tangente à curva de pressão de vapor $\left(\mathrm{kPa}^{\circ} \mathrm{C}^{-1}\right) ; \gamma=$ constante psicrométrica $\left(\mathrm{kPa}^{\circ} \mathrm{C}^{-1}\right)$.

A estimativa da evapotranspiração da cultura do milho (equação 3 ) foi realizada utilizando os valores de coeficiente da cultura $(\mathrm{Kc})$ específicos para o milho (Allen, et al., 1998). Os valores de Kc foram iguais a: 1,0 para os primeiros 55 dias; 1,2 dos 56 aos 96 dias após a semeadura; e 0,6 dos 97 dias após a semeadura até a maturidade 
fisiológica, de acordo com a recomendado por Allen et al. (1998), para milho cultivado em região subtropical.

$\mathrm{ET}_{\mathrm{c}}=\mathrm{K}_{\mathrm{c}} \mathrm{ET}_{\mathrm{o}}$

Para o experimento realizado em condições de sequeiro no ano de 2002, o efeito da deficiência hídrica na ETc foi estimado usando-se o coeficiente de estresse hídrico, Ks, como apresentado na equação 4:

$\mathrm{ETa}=\mathrm{Ks} \mathrm{ET}_{\mathrm{c}}$

em que ETa = evapotranspiração real $\left(\mathrm{mm} \mathrm{dia}^{-1}\right)$.

Para a determinação de Ks foi necessário se estimar o balanço hídrico da zona radicular. Ks é um fator de redução adimensional dependente da disponibilidade de água no solo e que varia entre 0 e 1 . Para a fração da água rapidamente disponível, o fator Ks é considerado igual a 1. Quando a água no solo se torna limitante e a ETa passa a ser menor do que a ETc, Ks decresce em proporção à quantidade de água remanescente na região radicular (Allen, et al., 1998). Nos experimentos irrigados, como não foram impostas limitações de água a ETa foi sempre igual à ETc.

Nos experimentos realizados em 2002, o conteúdo de água no solo foi determinado três vezes, uma vez antes da semeadura e duas vezes durante o período vegetativo utilizando-se o método gravimétrico. Além disso, a umidade do solo foi monitorada a cada dois dias com três baterias de tensiômetros instalados nas profundidades de: $20,40,55$ e $70 \mathrm{~cm}$.

\subsubsection{Eficiência de uso da água}

A eficiência de uso da água $\left(\mathrm{kg} \mathrm{ha}^{-1} \mathrm{~mm}^{-1}\right)$ para a cultura de milho foi determinada como sendo a relação entre a produção da cultura (rendimento em grãos, $\left.\mathrm{kg} \mathrm{ha}^{-1}\right)$ e a $\mathrm{ETa}(\mathrm{mm})$ (equação 5). 
$W U E=\frac{Y}{E T a}$

em que $\mathrm{Y}=$ rendimento em grão $\left(\mathrm{kg} \mathrm{ha}^{-1}\right)$.

As estimativas de eficiência de uso da água (WUE) foram conduzidas para cada tratamento nos três experimentos estudados. Adicionalmente, WUE por unidade de água utilizada pela cultura depois de descontada a água proveniente da chuva (WUEi-r) foi determinada pela equação 6 . O incremento na produção de milho no experimento sob irrigação foi assumido como sendo devido somente à água proveniente da irrigação.

$\mathrm{WUE}_{\mathrm{i}-\mathrm{r}}=\frac{\left(\mathrm{Y}_{\mathrm{i}}-\mathrm{Y}_{\mathrm{r}}\right)}{\left(\mathrm{ETc}_{\mathrm{i}}-\mathrm{ETa}_{\mathrm{r}}\right)}$

em que $Y_{i}=$ rendimento $\left(\mathrm{kg} \cdot \mathrm{ha}^{-1}\right)$ sob condições irrigadas, $\mathrm{Yr}=$ rendimento $\left(\mathrm{kg} \cdot \mathrm{ha}^{-1}\right)$ sob condições de sequeiro, $\mathrm{ETc}_{\mathrm{i}}=$ evapotranspiração sob condições irrigadas, $\mathrm{ETa}_{\mathrm{r}}=$ evapotranspiração sob condições de sequeiro.

\subsubsection{Quebra de rendimento}

Para quantificar o efeito da deficiência hídrica no rendimento, foi estimada a redução de rendimento para cada híbrido por meio da equação 7 :

Yred $=\left[1-\left(\frac{Y_{r}}{Y_{i}}\right)\right] * 100$

em que Yred é a redução do rendimento. 


\subsubsection{Análise estatística}

Foi realizada a análise de variância (ANOVA) para testar o efeito do híbrido e da irrigação nos componentes do rendimento. As análises incluíram procedimentos do programa SAS, ANOVA para analisar cada experimento individualmente e modelos lineares gerais (GLM) para analisar os três experimentos como grupo (SAS Inst., 2001). Quando o teste $\mathrm{F}$ foi significativo ao nível menor de 0,05 , as médias foram comparadas utilizando-se o teste da diferença mínima significativa (LSD) ao nível $\mathrm{P}_{0,05}$. Foram realizadas análises de regressão linear simples e múltiplas para identificar a relação entre o rendimento e os seus componentes e entre a evapotranspiração real e o rendimento da cultura de milho "safrinha".

\subsection{Resultados e discussão}

\subsubsection{Condições climáticas e hídricas do solo}

As altas temperaturas observadas durante a estação de crescimento do ano 2002 aceleraram o crescimento e o desenvolvimento da cultura do milho safrinha, induzindo a uma redução no número de dias desde a semeadura até o florescimento, em relação ao ano 2001. Para os primeiros 70 dias da estação de crescimento (período que leva em conta desde a semeadura até o florescimento de todos os híbridos), a temperatura máxima média foi de $28,5^{\circ} \mathrm{C}$ e a mínima de $16,1^{\circ} \mathrm{C}$ em 2001 ; enquanto que no ano 2002 estas temperaturas foram respectivamente $29,7^{\circ} \mathrm{C}$ e $17,7^{\circ} \mathrm{C}$. A Figura 1a apresenta a variação da temperatura média diária do ar ao longo das duas estações de cultivo e nela pode-se constatar a predominância de temperaturas mais elevadas no ano de 2002.

A quantidade de água aplicada em cada irrigação, a precipitação e a soma dessas variáveis durante as estações de crescimento dos anos 2001 e 2002 são apresentadas nas Figuras 1 b e 1c. A água proveniente da precipitação foi da ordem de $212 \mathrm{~mm}$ para o ano 2001 e de 363 mm para o ano 2002, enquanto que o total de água aplicado via irrigação foi de $334 \mathrm{~mm}$ em 2001 e de $261 \mathrm{~mm}$ em 2002. 

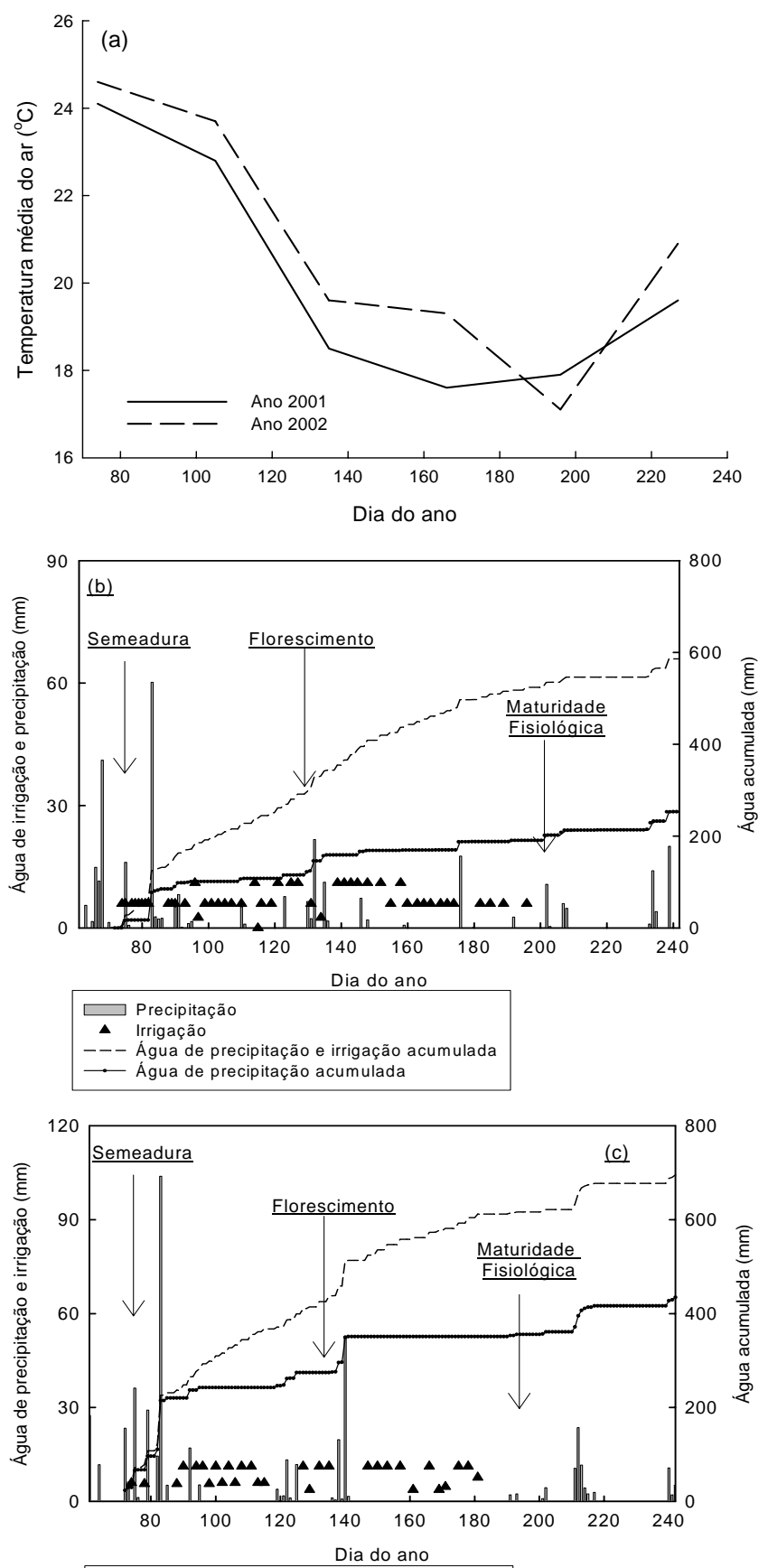

$$
\begin{aligned}
& \square \text { Precipitação } \\
& \text { Irrigação } \\
& -- \text { A Agua de precipitação e irrigação acumulada } \\
& \text { - Precipitação acumulada }
\end{aligned}
$$

Figura 1 - Temperatura média do ar para as estações de crescimento dos anos 2001 e 2002 (a) e irrigação, precipitação, e água acumulada para as estações de crescimento dos anos 2001 (b) e 2002 (c) em Piracicaba, Estado de São Paulo, Brasil. 
A estação de crescimento do ano 2002 teve períodos sem chuva principalmente entre os dias do ano 95 e 120 (período vegetativo) e entre os dias 150 e 190 (enchimento dos grãos). A chuva no começo e no meio de maio foi importante para o período mais crítico da cultura, entorno do florescimento.

O conteúdo de água no solo referente ao ano de 2002, medido com o método gravimétrico, é ilustrado na Figura 2a. Os mais baixos valores de conteúdo de água no solo medidos no experimento sob condições de sequeiro indicaram que a cultura esteve submetida a condições limitantes de disponibilidade de água durante a fase vegetativa. $\mathrm{O}$ conteúdo de água no solo foi crítico a $60 \mathrm{~cm}$ de profundidade, indicando que sob condições de sequeiro as raízes cresceram até horizontes mais profundos extraindo água nesses níveis. Essa observação também foi registrada nas leituras dos tensiômetros (Figura 2b). Observou-se que os tensiômetros instalados a $20 \mathrm{~cm}$ de profundidade foram os primeiros a mostrar incrementos no potencial matricial, indicando o rápido consumo de água nas camadas superiores do solo, aproximadamente no dia 98, ou seja , 26 dias depois da semeadura. Os tensiômetros instalados a $40 \mathrm{~cm}$ de profundidade apresentaram aumento do potencial matricial, aproximadamente no dia 103. Cinco dias depois, foi observado um incremento no potencial matricial nos tensiômetros instalados a $55 \mathrm{~cm}$. O incremento da tensão da água no solo nos tensiômetros instalados a $70 \mathrm{~cm}$ foi verificado no dia 112 (41 dias após a semeadura). Essa observação confirma que as raízes consumiram água desde as camadas superficiais no inicio do ciclo, até camadas mais profundas em resposta à deficiência de água. Ainda, a limitação de água afetou o crescimento das plantas de milho e sintomas de estresse foram observados, como enrolamento das folhas. Os tensiômetros foram expostos a altos valores de tensão de água no solo não sendo capazes de mensurar os altos valores do potencial matricial.

Sob condições de irrigação em 2002, só a camada superior do solo $(20 \mathrm{~cm}$ de profundidade) mostrou oscilações nas leituras dos tensiômetros, enquanto que nas camadas mais profundas os potenciais matriciais se mantiveram estáveis, próximo da capacidade de campo, indicando que a cultura não foi submetida a deficiência hídrica (Figura 2c). 

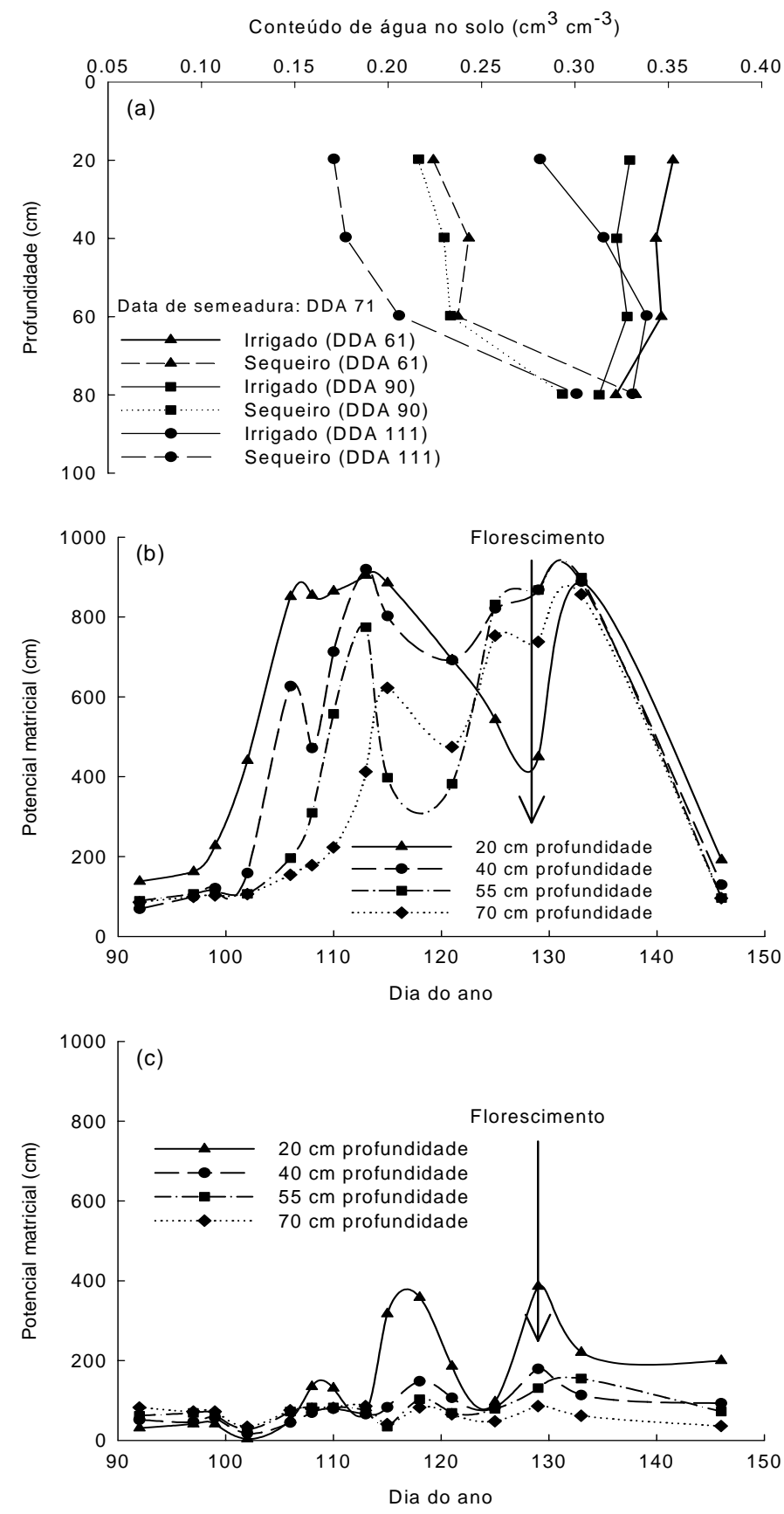

Figura 2 - Variação temporal do conteúdo de água no solo medido com o método gravimétrico durante a fase vegetativa do milho para o experimento irrigado e de sequeiro em 2002 (a) e leituras dos tensiômetros nos experimentos de sequeiro (b) e irrigados (c) em 2002. DDA = dia do ano. 


\subsubsection{Altura das plantas, área foliar e acúmulo de matéria seca}

Em geral, as limitações de água impostas à cultura de milho "safrinha" determinaram uma menor altura das plantas sob condições de sequeiro nos quatro híbridos. Estas diferenças foram evidentes depois do acúmulo de $600{ }^{\circ} \mathrm{Cd}$ (Figura 3). O híbrido AG9010 (super-precoce) teve as plantas mais baixas entre os quatro híbridos estudados sob condições de sequeiro $(175 \mathrm{~cm})$ e sob condições irrigadas $(200 \mathrm{~cm})$. A redução na altura desse híbrido foi mas evidente do que nos demais híbridos, com uma redução de 13\%. O híbrido Exceler foi o mais alto sob condições irrigadas e de sequeiro, com 230 e $227 \mathrm{~cm}$ de altura, respectivamente.
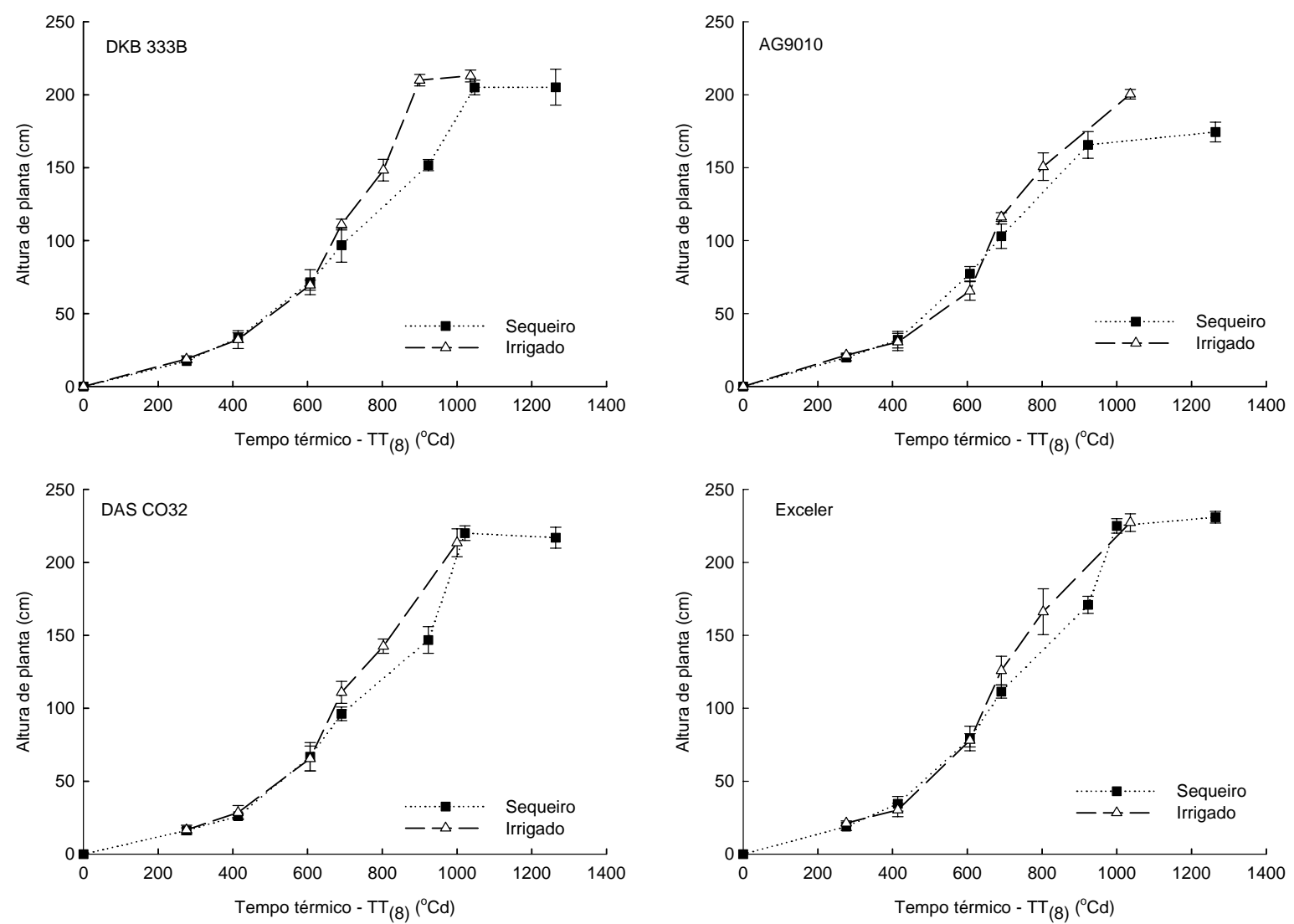

Figura 3 - Altura média das plantas e desvio padrão em função do tempo térmico para os quatro híbridos nos experimentos sob irrigação e de sequeiro, conduzidos em Piracicaba, SP, Brasil, durante a "safrinha" do ano de 2002. 
A altura máxima para os híbridos DKB 333B e DAS CO32 foram de 213 e 217 cm, sendo similares sob condições de irrigação. Nesses híbridos a redução na altura da planta sob condições de sequeiro foi de menos de $5 \%$.

O índice de área foliar (IAF) máximo foi atingido por volta do estágio do florescimento, aproximadamente $900{ }^{\circ} \mathrm{Cd}$ após a semeadura (Figura 4). As últimas medidas de IAF, conduzidas por volta dos $1250{ }^{\circ} \mathrm{Cd}$ para os híbridos sob condições de sequeiro, mostraram um decréscimo no IAF. Uma variação comum foi observada no IAF dos quatro híbridos, o que pode ser observado nos desvio padrões ilustrados na Figura 4. Essa variação no IAF pode ser explicada pela variabilidade espacial natural das condições físico-hídricas do solo e por erros experimentais, tais como diferentes distâncias entre plantas e outras fontes de erro normalmente associadas com experimentos de campo, que resultam em diferentes tamanhos de plantas e de folhas. Os híbridos DKB 333B e DAS CO32 tiveram os maiores valores de IAF sob irrigação no ano de 2001 e os menores valores sob condições de sequeiro no ano de 2002 (Figura 4). Os híbridos AG9010 e Exceler tiveram valores similares de IAF nos três experimentos, no entanto, em 2001 observou-se uma tendência de maiores valores de IAF, principalmente antes do florescimento. O híbrido AG9010 (super-precoce) teve os menores IAF máximos $\left(2,5\right.$ até $\left.2,8 \mathrm{~m}^{2} \mathrm{~m}^{-2}\right)$ em relação aos outros híbridos nos três experimentos. 

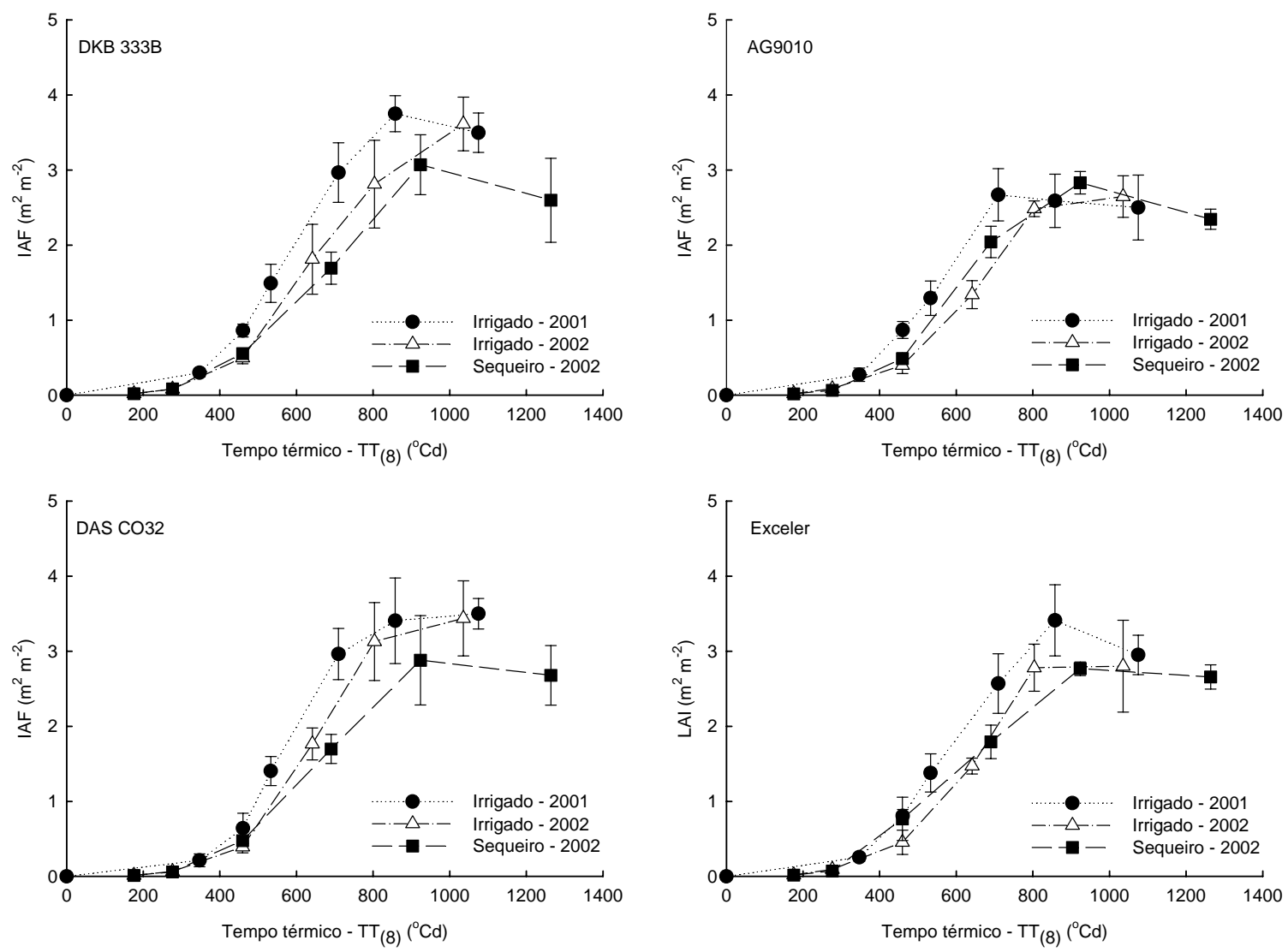

Figura 4 - Índice de área foliar médio e desvio padrão em função do tempo térmico para os quatro híbridos nos três experimentos realizados em Piracicaba, SP, Brasil, durante a "safrinha" dos anos 2001 e 2002. O estágio de florescimento feminino ocorreu aproximadamente entre 900 e $1040{ }^{\circ} \mathrm{Cd}$ para os híbridos de ciclo super-precoce e normal, respectivamente.

As taxas de acúmulo de matéria seca desde a semeadura até a colheita apresentaram um padrão similar entre os quatro híbridos, com as maiores taxas de incremento até $1250{ }^{\circ} \mathrm{Cd}$ passando a ser menores depois disso. Essas observações sugerem que a translocação de carbohidratos durante a fase de enchimento dos grãos é importante na definição do rendimento em grão. Para o milho semeado no ano 2001, foram observadas maiores taxas de acúmulo de matéria seca, principalmente antes do florescimento, para todos os híbridos (Figura 5). Durante essa estação de crescimento, menores valores de temperatura do ar foram registrados (Figura 1a), o que determinou o 
desenvolvimento mais lento da cultura e, conseqüentemente, um maior número de dias entre a semeadura e o florescimento feminino. O híbrido de ciclo normal, DKB 333B, e o híbrido de ciclo super-precoce, AG9010, tiveram as maiores diferenças em termos de matéria seca na colheita entre as condições irrigada e de sequeiro, no ano de 2002. A colheita foi realizada aproximadamente aos $2000{ }^{\circ} \mathrm{Cd}$ para o híbrido de ciclo superprecoce, AG9010, e aos $2250{ }^{\circ} \mathrm{Cd}$ para os demais.
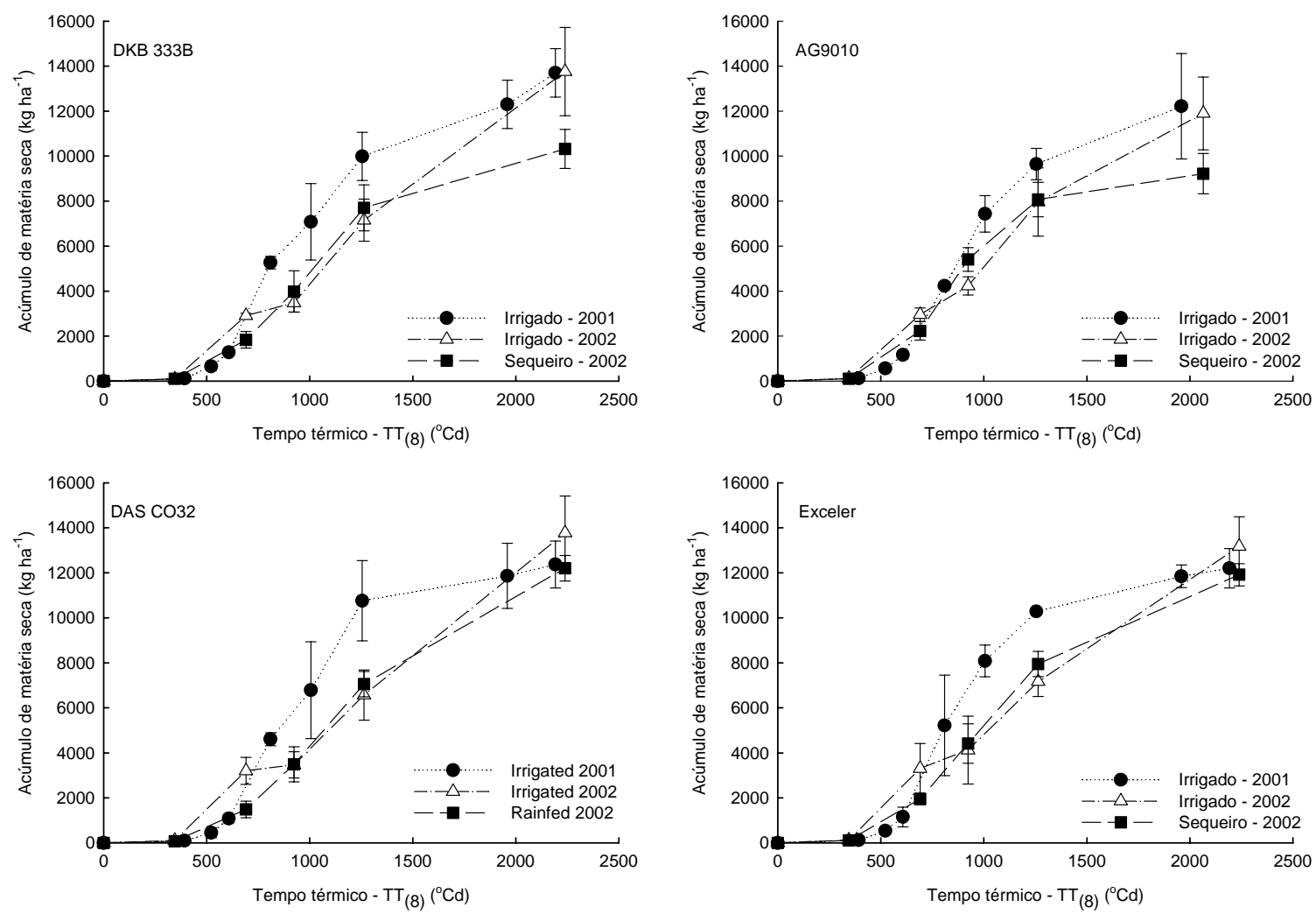

Figura 5 - Acúmulo de matéria seca e desvio padrão em função do tempo térmico para os quatro híbridos nos três experimentos realizados em Piracicaba, SP, Brasil, durante a "safrinha" dos anos de 2001 e 2002.

\subsubsection{Componentes do rendimento}

A média do número de grãos por espiga não foi significativamente diferente nos três experimentos (Tabela 1). Sob condições irrigadas do ano 2002, o híbrido Exceler foi 
estatisticamente diferente dos outros híbridos, com 469 grãos. Não foram encontradas diferenças nos quatro híbridos sob condições irrigadas durante o ano 2001 e sob condições de sequeiro no ano 2002. Os híbridos de ciclo curto, Exceler e DASCO32, apresentaram maior número de grãos por espiga em média, respectivamente 446 e 431 e foram significativamente diferentes do híbrido DKB 333B, que apresentou em média 407 grãos por espiga.

Tabela 1 - Número de grãos por espiga e massa do grão para os quatro híbridos de milho nos três experimentos realizados em Piracicaba, SP, Brasil, durante a "safrinha" dos anos 2001 e 2002.

\begin{tabular}{|c|c|c|c|c|c|c|}
\hline \multirow{3}{*}{$\begin{array}{l}\text { Híbridos } \\
\text { AG9010 }\end{array}$} & \multicolumn{5}{|c|}{ Grãos por espiga } & \multirow{3}{*}{$\begin{array}{l}\text { Média } \\
414 \text { (bc) }\end{array}$} \\
\hline & Irrigado 2001 & \multicolumn{2}{|c|}{ Irrigado 2002} & \multicolumn{2}{|c|}{ Sequeiro 2002} & \\
\hline & $414 \quad$ (a) & 427 & (b) & 401 & (a) & \\
\hline DKB 333B & 413 (a) & 417 & (b) & 394 & (a) & 407 (c) \\
\hline DAS CO32 & $449 \quad$ (a) & 432 & (b) & 416 & (a) & $431(\mathrm{ab})$ \\
\hline Exceler & $453 \quad$ (a) & 469 & (a) & 417 & (a) & 446 (a) \\
\hline \multirow[t]{2}{*}{ Média } & 432 (A) & \multicolumn{2}{|c|}{436 (A) } & \multicolumn{2}{|c|}{407 (A) } & \\
\hline & \multicolumn{6}{|c|}{ Massa do grão (mg) } \\
\hline Híbridos & Irrigado 2001 & \multicolumn{2}{|c|}{ Irrigado 2002} & \multicolumn{2}{|c|}{ Sequeiro 2002} & Média \\
\hline AG9010 & $241 \quad$ (a) & 231 & (b) & 232 & (a) & $234(a)$ \\
\hline DKB 333B & $252 \quad$ (a) & 251 & (a) & 225 & (a) & 242 (a) \\
\hline DAS CO32 & $248 \quad$ (a) & 228 & (b) & 228 & (a) & 234 (a) \\
\hline Exceler & $255 \quad$ (a) & 238 & $(\mathrm{ab})$ & 238 & (a) & 243 (a) \\
\hline Média & 249 (A) & \multicolumn{2}{|c|}{237 (AB) } & \multicolumn{2}{|c|}{231 (B) } & \\
\hline
\end{tabular}

As médias foram comparadas com o teste da diferença mínima significativa (LSD) com $\mathrm{P} \leq 0,05$. Médias seguidas por letras diferentes foram significativamente diferentes na mesma coluna. Para as médias, números seguidos por letras diferentes foram significativamente diferentes na mesma linha. 
Quando a média de massa do grão dos três experimentos foi comparada, foi observado na condição irrigada de 2001 um maior valor (249 mg) para os quatro híbridos estudados. No entanto, este valor não foi significativamente diferente do outro experimento conduzido sob irrigação no ano de 2002 (Tabela 1). Grant et al. (1989) verificaram que o estresse hídrico durante o período de enchimento dos grãos afetou o peso desses. As diferenças na massa dos grãos pode ser atribuída a um peso inicial baixo, a baixas taxas de enchimento ou, ainda, a uma curta duração do período de enchimento na máxima taxa linear. Não foram observadas diferenças significativas na massa do grão entre os experimentos irrigado e de sequeiro conduzidos durante o ano 2002. A análise estatística da massa do grão para os quatro híbridos em cada um dos experimentos resultou em diferenças significativas somente para o híbrido DKB 333B (251 mg) sob condição irrigada no ano 2002, porém não foi diferente do híbrido Exceler.

Ao analisar o número de espigas por metro quadrado, foi encontrado que os maiores valores médios dos quatro híbridos foram atingidos no ano de 2001 sob condições irrigadas (Tabela 2), porém não foi significativamente diferente do valor obtido no experimento irrigado do ano de 2002. Não foram observadas diferenças entre o número médio de espigas por metro quadrado nos experimentos sob condições irrigadas e de sequeiro do ano de 2002. Diferenças entre híbridos foram encontradas no experimento conduzido durante o ano 2002, no qual o híbrido DAS CO32 apresentou maior número de espigas por metro quadrado $(5,6)$ do que o híbrido Exceler $(4,9)$. Não foram encontradas diferenças no número de espigas por metro quadrado entre híbridos nos experimentos conduzidos durante o ano 2001 sob condições irrigadas e durante o ano 2002 sob condições de sequeiro. 
Tabela 2 - Número de espigas e de grãos por metro quadrado para os quatro híbridos nos três experimentos realizados em Piracicaba, SP, Brasil, durante a "safrinha" dos anos de 2001 e 2002 .

\begin{tabular}{|c|c|c|c|c|}
\hline \multicolumn{5}{|c|}{ Espigas por metro quadrado } \\
\hline Híbridos & Irrigado 2001 & Irrigado 2002 & Sequeiro 2002 & Média \\
\hline AG9010 & 5,3 (a) & $5,4(a b)$ & 4,5 (a) & 5,0 (a) \\
\hline DKB 333B & 5,7 (a) & $4,9(a b)$ & $5,1 \quad$ (a) & $5,2(a)$ \\
\hline DAS CO32 & 5,3 (a) & 5,6 (a) & 4,8 (a) & $5,1(a)$ \\
\hline Exceler & 5,8 (a) & 4,9 (b) & 5,2 (a) & 5,2 (a) \\
\hline Média & $5,51(A)$ & $5,15(\mathrm{AB})$ & $4,91(\mathrm{~B})$ & \\
\hline \multicolumn{5}{|c|}{ Grãos por metro quadrado } \\
\hline Híbridos & Irrigado 2001 & Irrigado 2002 & Sequeiro 2002 & Média \\
\hline AG9010 & 2.191 (a) & 2.318 (a) & 1.801 (b) & $2.103(b)$ \\
\hline DKB 333B & 2.366 (a) & 2.078 (a) & $2.028(a b)$ & $2.157(a b)$ \\
\hline DAS CO32 & 2.362 (a) & 2.308 (a) & $2.011(\mathrm{ab})$ & $2.227(\mathrm{ab})$ \\
\hline Exceler & 2.622 (a) & 2.286 (a) & 2.152 (a) & $2.353(a)$ \\
\hline Média & $2.386(\mathrm{~A})$ & 2.247 (AB) & 1.998 (B) & \\
\hline
\end{tabular}

As médias foram comparadas com o teste da diferença mínima significativa (LSD) com $\mathrm{P} \leq 0,05$. Médias seguidas por letras diferentes foram significativamente diferentes na mesma coluna. Para as médias, números seguidos por letras diferentes foram significativamente diferentes na mesma linha.

Sob as condições do experimento conduzido sob irrigação, no ano 2001, foi observado o maior valor de número de grãos por metro quadrado (2.386), porém este não foi estatisticamente diferente do valor obtido no experimento irrigado do ano 2002 (2.247). Não foram encontradas diferenças entre o número médio de grãos por metro quadrado entre os experimentos irrigado e de sequeiro conduzidos durante o ano 2002. Sob condições de sequeiro no ano 2002, o híbrido Exceler foi estatisticamente diferente do híbrido AG9010. Já nos experimentos sob irrigação conduzidos nos anos 2001 e 2002, não houveram diferenças no número de grãos por metro quadrado entre os diferentes híbridos. Quando analisaram-se os três experimentos, foi observado que o 
híbrido de ciclo curto Exceler foi o que teve maior número de grãos por metro quadrado (2.353) significativamente diferente do híbrido de ciclo super-precoce AG9010 (2.103).

\subsubsection{Rendimento e índice de colheita}

O rendimento médio para os quatro híbridos dos experimentos sob irrigação dos anos 2001 e 2002 não foram estatisticamente diferentes, assim como também não foram encontradas diferenças entre os experimentos sob irrigação e sob sequeiro conduzidos durante o ano 2002 (Tabela 3).

Thompson (1986) analisando uma série de dados climáticos e agronômicos da cultura do milho, concluiu que anos com baixas temperaturas estiveram associadas, em geral, com maiores rendimentos de grãos. A estação de crescimento do ano de 2001 caracterizou-se por possuir temperaturas mais baixas do que as do ano de 2002, no entanto, não foram observadas diferenças estatísticas entre os experimentos conduzidos nestes dois anos.

Diferenças significativas no rendimento entre os híbridos, dentro de cada experimento, foram observadas (Tabela 3) apenas para o híbrido Exceler sob condições de sequeiro do ano 2002, com valores superiores aos dos híbridos AG9010, DAS CO32, e DKB 333B. Também, o híbrido Exceler teve o maior rendimento médio considerandose os três experimentos. O rendimento do híbrido super-precoce (AG 9010), do híbrido de ciclo curto (DAS CO32), e o do ciclo normal (DKB 333B) não apresentaram diferenças entre si. Aparentemente, outros fatores, além da duração do ciclo, são importantes na definição do rendimento do milho, ainda que sob condições de sequeiro. O híbrido $\mathrm{DKB}$ 333B, de ciclo normal, foi o mais afetado pela restrição na disponibilidade de água no solo, com uma quebra de rendimento de $25,6 \%$ enquanto que o híbrido Exceler foi o menos afetado pelo estresse hídrico, com 8,4\% de redução no seu rendimento.

A limitação de água no solo nas fases vegetativa e reprodutiva determinou, em média, quebras de rendimento da ordem de $18 \%$ quando se comparam os experimentos conduzidos sob irrigação e sequeiro no ano de 2002. É importante destacar que houve 
quantidades diferentes de fertilizantes entre os experimentos irrigados e de sequeiro, que é uma outra fonte de variação. No entanto, considerou-se tal fato irrelevante pois a maior condição limitante ao rendimento foi a redução na disponibilidade de água no solo.

Tabela 3 - Rendimento de quatro hibridos de milho em três experimentos realizados em Piracicaba, SP, Brasil, durante a "safrinha" dos anos de 2001 e 2002.

\begin{tabular}{llllllll}
\hline Híbridos & \multicolumn{2}{l}{$\begin{array}{l}\text { Irrigado 2001 } \\
\text { kg ha }\end{array}$} & \multicolumn{2}{l}{$\begin{array}{l}\text { Irrigado 2002 } \\
\mathbf{k g ~ h a}^{-1}\end{array}$} & $\begin{array}{l}\text { Sequeiro 2002 } \\
\mathbf{k g ~ h a}^{-1}\end{array}$ & $\begin{array}{l}\text { Média } \\
\mathbf{k g ~ h a}^{-1}\end{array}$ \\
\hline AG9010 & 5.028 & (a) & 4.986 & (a) & 4.044 & (b) & 4.686 (b) \\
DKB 333B & 5.801 & (a) & 5.139 & (a) & 3.822 & (b) & 4.921 (b) \\
DAS CO32 & 5.684 & (a) & 5.047 & (a) & 4.109 & (b) & 4.947 (b) \\
Exceler & 5.863 & (a) & 5.306 & (a) & 4.859 & (a) & 5.343 (a) \\
Média & $\mathbf{5 . 5 9 4}$ (A) & $\mathbf{5 . 1 1 9}$ (AB) & $\mathbf{4 . 2 0 8 , 6 ~ ( B ) ~}$ &
\end{tabular}

As médias foram comparadas com o teste da diferença mínima significativa (LSD) com $\mathrm{P} \leq 0,05$. Médias seguidas por letras diferentes foram significativamente diferentes na mesma coluna. Para as médias, números seguidos por letras diferentes foram significativamente diferentes na mesma linha.

O índice de colheita (IC), que corresponde à relação entre a massa de grãos e o total de matéria seca da parte aérea, é um indicador da proporção da matéria seca que foi destinada aos grãos. O maior valor de IC foi obtido no experimento conduzido durante o ano de 2001 sob condições de irrigação $(0,44)$, provavelmente explicado pelas condições climáticas favoráveis para a cultura do milho durante esse ano (Tabela 4). No entanto, esse valor de IC é menor do que 0,5, valor mais freqüente para o milho. De acordo com Hay e Gilbert (2001), o índice de colheita para o milho cultivado em regiões tropicais pode variar inconsistentemente com a estação, o manejo e o ambiente. O efeito das condições climáticas do outono e do inverno nesta região subtropical sob estudo limitou o rendimento do milho, explicando o menor índice de colheita obtido. A média de índice de colheita não foi diferente entre os experimentos irrigado e de sequeiro conduzidos durante o ano de 2002 (Tabela 4). Os híbridos AG9010 e Exceler tiveram os maiores 
índices de colheita nos experimentos conduzidos durante o ano de 2002 e, em geral, o maior índice de colheita médio.

Tabela 4 - Índice de colheita para quatro híbridos de milho em três experimentos realizados em Piracicaba, SP, Brasil, durante a "safrinha" dos anos 2001 e 2002.

\begin{tabular}{lcccc}
\hline Híbrido & Irrigado 2001 & Irrigado 2002 & Sequeiro 2002 & Média \\
\hline AG9010 & 0,41 & 0,42 & 0,44 & 0,42 \\
DKB 333B & 0,42 & 0,37 & 0,37 & 0,39 \\
DAS CO32 & 0,46 & 0,37 & 0,34 & 0,39 \\
Exceler & 0,48 & 0,40 & 0,41 & 0,43 \\
Média & $\mathbf{0 , 4 4}$ & $\mathbf{0 , 3 9}$ & $\mathbf{0 , 3 9}$ & \\
\hline
\end{tabular}

\subsubsection{Relação entre o rendimento e seus componentes}

A análise de regressão linear múltipla realizada para os quatro híbridos nos três experimentos evidenciou que a massa do grão foi o componente do rendimento mais relacionado com o rendimento da cultura do milho safrinha, seguido pelo número de grãos por espiga e pelo número de espigas por metro quadrado (Figura 6). No entanto, ao se resumir dois dos componentes do rendimento, número de grãos por espiga e número de espigas por metro quadrado, como número de grãos por metro quadrado, este último componente apresentou um maior grau de relação com o rendimento seguido pela massa do grão. Esses resultados concordaram com trabalhos prévios que verificaram que o rendimento do milho é altamente associado ao número de grãos por unidade de superfície (Andrade et al., 1996). Pandey et al. (2001) também encontraram que o rendimento em grãos esteve associado primeiramente com o número de grãos por metro quadrado e em segundo lugar com a massa do grão, quando deficiências hídricas foram impostas durante as fases vegetativa e reprodutiva. 


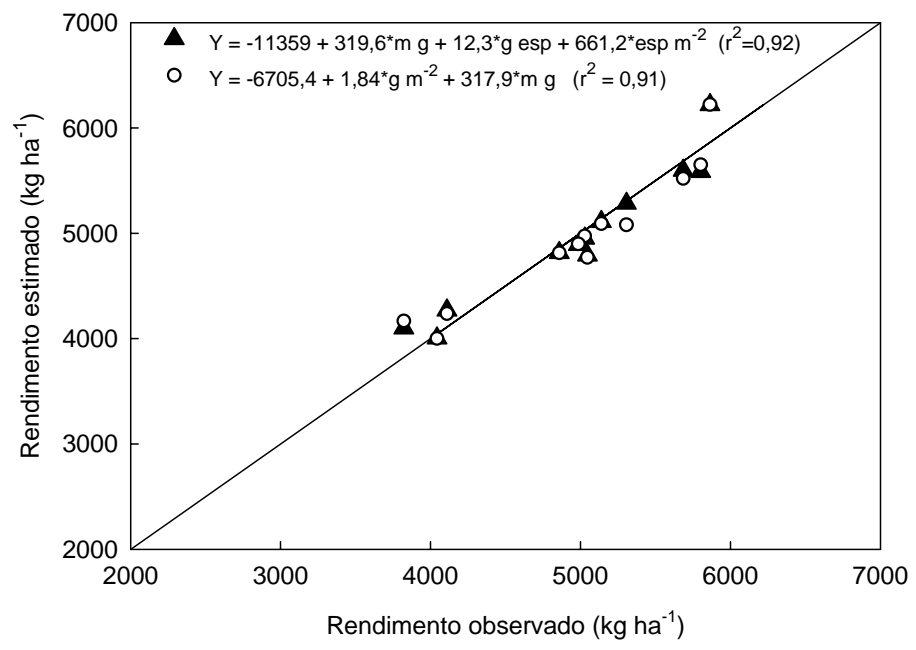

Figura 6 - Relação entre o rendimento estimado por dois modelos multilineares e o rendimento observado para quatro híbridos de milho em três experimentos realizados em Piracicaba, SP, Brasil, durante a "safrinha" dos anos de 2001 e 2002. ( $\mathrm{m} \mathrm{g}=$ massa de grãos; g esp = grãos por espiga; esp $\mathrm{m}^{-2}=$ espigas por metro quadrado; $\mathrm{g} \mathrm{m}^{-2}=$ grãos por metro quadrado).

Ao analisar cada híbrido nos três experimentos, foi observado que cada um deles teve diferentes componentes mais associados ao rendimento (Tabela 5). Para o híbrido super-precoce, AG9010, e para o híbrido de ciclo curto, Exceler, o número de grãos por metro quadrado foi o componente mais relacionado com o rendimento, com coeficientes de correlação de 0,84 e 0,76 , respectivamente. Para os híbridos DKB 333B e DAS CO32, a massa do grão foi o componente do rendimento mais associado com o rendimento, com coeficientes de correlação de 0,86 e 0,80, respectivamente. Número de grãos por espiga e número de espigas por metro quadrado tiveram uma importância secundária na determinação do rendimento. Bolaños e Edmeades (1996) verificaram para o milho, sob condições de severo estresse hídrico, valores de coeficiente de correlação igual a 0,90 entre o rendimento em grãos e o número de espigas por planta e de 0,71 entre o rendimento em grãos e o número de grãos por espiga. 
Tabela 5 - Coeficientes de correlação entre o rendimento da cultura do milho "safrinha" e seus diferentes componentes para quatro híbridos cultivados nos três experimentos realizados em Piracicaba, SP, Brasil, durante os anos de 2001 e 2002.

\begin{tabular}{lcccc}
\hline Híbridos & $\begin{array}{c}\text { Grãos } \mathbf{~ m}^{-2} \\
\text { (número) }\end{array}$ & $\begin{array}{c}\text { Massa grão } \\
\text { (mg) }\end{array}$ & $\begin{array}{c}\text { Grãos por espiga } \\
\text { (número) }\end{array}$ & $\begin{array}{c}\text { Espigas m } \\
\text { (número) }\end{array}$ \\
\hline AG9010 & 0,84 & 0,30 & 0,50 & 0,74 \\
DKB 333B & 0,67 & 0,86 & 0,75 & 0,46 \\
DAS C032 & 0,22 & 0,80 & 0,25 & 0,14 \\
Exceler & 0,76 & 0,51 & 0,41 & 0,59 \\
\hline
\end{tabular}

\subsubsection{Relação entre evapotranspiração e rendimento}

A evapotranspiração total para a cultura de milho nas estações de crescimento dos anos de 2001 e de 2002 foi similar, com média de 330 e 329 mm, respectivamente (Tabela 6). No entanto, para as condições de sequeiro do ano de 2002, menores valores de evapotranspiração (ETa) foram obtidos, os quais variaram entre $285 \mathrm{~mm}$ para o híbrido de ciclo curto AG9010 e 298 mm para o híbrido de ciclo normal DKB 333B. Esses valores de evapotranspiração foram menores do que o total de chuva durante a estação de crescimento, o que pode ser creditado ao fato de algumas chuvas intensas terem provocado considerável escoamento superficial na área do experimento. Valores similares foram apresentados por Mishra et al. (2001), que encontrou ETa na "safrinha" variando entre $223 \mathrm{~mm}$ para o milho sob condições de sequeiro e $364 \mathrm{~mm}$ para o milho sob irrigação. Altos valores de ETa são comumente apresentados na literatura para o milho cultivado no verão em regiões subtropicais e temperadas, abrangendo valores entre 354 mm (Tyagi et al., 2003), 673 mm (Howell et al., 1998) e $920 \mathrm{~mm}$ (Karam et al., 2003), o que, no entanto, depende das condições climáticas vigentes em cada local e da disponibilidade hídrica dos solos. 
Tabela 6 - Evapotranspiração total da cultura (ETc) e real (ETa) para quatro híbridos de milho em três experimentos realizados em Piracicaba, SP, Brasil, durante a "safrinha" dos anos de 2001 e 2002.

\begin{tabular}{lccc}
\hline Híbrido & ETc $(\mathbf{m m})$ & ETc $(\mathbf{m m})$ & ETa $(\mathbf{m m})$ \\
\cline { 2 - 4 } & Irrigado 2001 & Irrigado 2002 & Sequeiro 2002 \\
\hline AG9010 & 320 & 317 & 285 \\
DKB 333B & 341 & 344 & 298 \\
DAS CO32 & 329 & 328 & 290 \\
Exceler & 329 & 328 & 290 \\
Média & $\mathbf{3 3 0}$ & $\mathbf{3 2 9}$ & $\mathbf{2 9 1}$ \\
\hline
\end{tabular}

De acordo com o apresentado na Figura 7, o rendimento do milho "safrinha" esteve relacionado com a quantidade de água evapotranspirada, sendo o coeficiente de determinação entre essas duas variáveis igual a 0,67. A inclinação da reta de regressão indica que para cada mm de água evapotranspirada pela cultura do milho "safrinha", a variação de rendimento esperada é, em média, de $26,8 \mathrm{~kg} \mathrm{ha}^{-1}$.

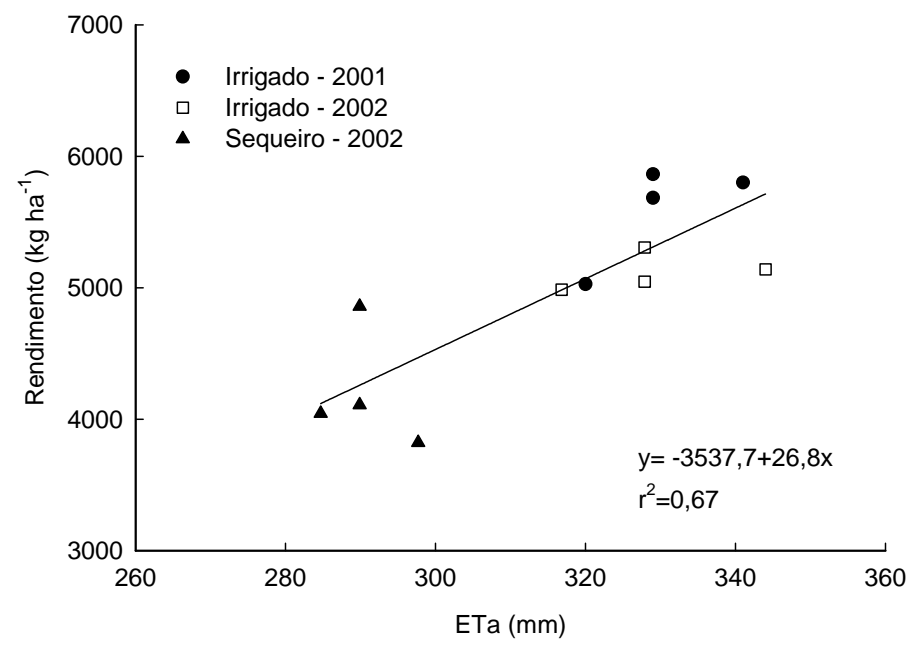

Figura 7 - Relação entre o rendimento e a evapotranspiração real (ETa) de quatro híbridos de milho em três experimentos realizados em Piracicaba, SP, Brasil, durante a "safrinha" dos anos de 2001 e 2002. 


\subsubsection{Eficiência de uso da água}

A eficiência de uso da água (WUE - $\mathrm{kg} \mathrm{ha}^{-1} \mathrm{~mm}^{-1}$ ) foi maior no experimento conduzido sob condições de irrigação no ano de 2001, o que significa que nas condições desse ano, maior quantidade de massa de grãos foi produzida por $1 \mathrm{~mm}$ de água utilizada pela cultura (Tabela 7). Como a evapotranspiração da cultura foi similar entre os dois anos estudados, as diferenças em WUE entre os experimentos sob irrigação e de sequeiro são devidas aos maiores rendimentos obtidos no ano 2001. Ao comparar os dois experimentos conduzidos no ano 2002, houve uma leve tendência de se ter menores valores de WUE sob condições de sequeiro $\left(14,5 \mathrm{~kg} \mathrm{ha}^{-1} \mathrm{~mm}^{-1}\right)$ do que sob condições de irrigação $\left(15,6 \mathrm{~kg} \mathrm{ha}^{-1} \mathrm{~mm}^{-1}\right)$.

A produtividade por unidade de água utilizada pela cultura acima daquela proveniente da chuva (WUEi-r) foi, em média para os quatro híbridos, de 23,6 kg ha ${ }^{-1}$ $\mathrm{mm}^{-1}$. Os menores valores foram obtidos com o híbrido de ciclo curto Exceler $(11,8 \mathrm{~kg}$ $\mathrm{ha}^{-1} \mathrm{~mm}^{-1}$ ), indicado que a resposta às irrigações não foi tão evidente neste híbrido como nos demais. Assumiu-se que o incremento na produção no experimento sob irrigação foi devido à água aplicada via irrigação. No entanto, a quantidade diferenciada de fertilizantes nos experimentos sob irrigação e de sequeiro aplicados pode ter causado um efeito secundário.

Tabela 7 - Eficiência de uso de água para quatro híbridos de milho nos três experimentos realizados em Piracicaba, SP, Brasil, durante a "safrinha" dos nos de 2001 e 2002.

\begin{tabular}{|c|c|c|c|c|}
\hline \multirow[t]{2}{*}{ Híbrido } & \multicolumn{3}{|c|}{ WUE (kg ha $\left.{ }^{-1} \mathrm{~mm}^{-1}\right)$} & \multirow{2}{*}{$\begin{array}{c}\text { WUEi-r } \\
\left(\mathrm{kg} \mathrm{ha}^{-1} \mathrm{~mm}^{-1}\right)\end{array}$} \\
\hline & Irrigado 2001 & Irrigado 2002 & Sequeiro 2002 & \\
\hline AG9010 & 15,7 & 15,7 & 14,2 & 29,3 \\
\hline DKB 333B & 17,0 & 14,9 & 12,8 & 28,4 \\
\hline DAS CO32 & 17,3 & 15,4 & 14,2 & 24,7 \\
\hline Exceler & 17,8 & 16,2 & 16,7 & 11,8 \\
\hline Média & 16,9 & 15,6 & 14,5 & 23,6 \\
\hline
\end{tabular}


É importante mencionar que devido à eficiência de uso da água ser o resultado da relação entre o rendimento e a evapotranspiração real, erros inerentes à estimativa da ETc podem estar inclusos nos cálculos. No entanto, tal informação parece ser valiosa pois é uma primeira abordagem do tema e que servirá de base para futuros estudos do milho "safrinha" em regiões subtropicais.

\subsection{Conclusões}

Baseados nos resultados obtidos neste estudo, o milho "safrinha", sob condições de sequeiro, apresentou, de um modo geral, menores valores de IAF, altura de planta e acúmulo de matéria seca do que sob condições de irrigação. A cultura submetida a limitação de água no solo determinou uma atividade radicular intensa nas camadas mais profundas do solo, sugerindo que um incremento no comprimento das raízes foi a resposta às deficiências hídricas.

A massa do grão e o número de grãos por metro quadrado foram os componentes mais associados ao rendimento. O híbrido de ciclo normal, DKB 333B, foi o mais afetado pela deficiência hídrica. O milho sob condições de sequeiro foi menos eficiente em termos do uso da água. Para produzir $1 \mathrm{~kg}$ de grãos foram necessários $0,69 \mathrm{~m}^{3} \mathrm{de}$ água, enquanto que sob condições de irrigação a quantidade de água necessária variou entre 0,59 e $0,64 \mathrm{~m}^{3}$.

$\mathrm{O}$ rendimento médio não foi afetado pelas condições limitantes de água no solo impostas no experimento de sequeiro, pois chuvas ocorridas por volta do florescimento e durante o estágio de enchimentos dos grãos ajudaram a se obter rendimentos razoáveis. Diferentes híbridos responderam de forma diferenciada à limitação de água no solo, indicando haver diferenças genotípicas na resposta ao estresse hídrico nos híbridos estudados, sendo a quebra de rendimento do híbrido DKB 333B, de ciclo normal, de 25,6\% enquanto que para o híbrido de ciclo curto Exceler, a redução de rendimento foi de apenas $8,4 \%$. 
A alta variabilidade da precipitação durante os meses de outono e inverno impõe a necessidade de se conduzir mais estudos para se avaliar a irrigação e a eficiência de uso da água pela cultura de milho na "safrinha" em ambientes subtropicais. 


\section{AVALIAÇÃO E USO DO MODELO CERES-Maize PARA A CULTURA DO MILHO (ZEA MAYS L.) SEMEADA NA "SAFRINHA", NO ESTADO DE SÃO PAULO}

\section{Resumo}

Nos últimos anos o milho tem se tornado em uma alternativa importante de cultivo durante o período de outono-inverno no Estado de São Paulo, Brasil. Défícit hídricos, temperaturas sub-ótimas e baixa quantidade de horas de sol são alguns dos problemas experimentados durante esta estação de crescimento. Uma das possíveis maneiras de se avaliar a resposta das culturas às diferentes condições climáticas é através dos modelos de simulação. O modelo CERES-Maize, incluído no Sistema de Suporte para Transferência de Agrotecnologia (DSSAT) v.4.0, foi parametrizado e testado com dados provenientes de três experimentos de campo, conduzidos em Piracicaba, SP, Brasil. Os três experimentos de campo tiveram delineamento de blocos completos ao acaso e incluíram os híbridos AG9010 (super-precoce), DAS CO32 e Exceler (precoces) e DKB 333B (ciclo normal), com 3 repetições para o experimento realizado em 2001 e 4 repetições para os dois experimentos conduzidos durante 2002. O modelo CERESMaize, foi usado para conduzir análise sazonal e para estimar a variabilidade do rendimento do milho "safrinha", usando dados climatológicos históricos. Estudou-se a relação entre o rendimento simulado e o fenômeno ENOS (El Niño Oscilação Sul ). O teste do modelo CERES-Maize, mostrou que este foi efetivo para simular a fenologia e o rendimento em grão, em razão dos valores do quadrado médio do erro (RMSE) terem sido menores do que $5 \%$. No entanto, alguns desvios foram observados nos componentes do rendimento, principalmente no híbrido de ciclo super-precoce, no qual foram obtidos 
os menores valores do Índice de Concordância (d) para o número de grãos por metro quadrado e massa de grãos. O IAF e o acúmulo de matéria seca foram razoavelmente bem estimados pelo modelo CERES-Maize para os híbridos de ciclo curto e normal. Porém, para o híbrido de ciclo super-precoce, AG9010, uma sub-estimativa do IAF e do acúmulo de matéria seca foi observada. Por exemplo, para esse híbrido sob condições de irrigação durante o ano 2001 o IAF máximo simulado foi de $2,1 \mathrm{~m}^{2} \mathrm{~m}^{-2} \mathrm{e}$ o valor observado foi de $2,7 \mathrm{~m}^{2} \mathrm{~m}^{-2}$. O método de simulação do balanço hídrico do modelo CERES-Maize simulou adequadamente a variação temporal do conteúdo de água no solo. Enquanto que o conteúdo de água no solo se manteve estável a $40 \mathrm{~cm}$ de profundidade sob condições de irrigação, sob condições de sequeiro o mesmo decresceu até os $80 \mathrm{~cm}$ de profundidade, indicando que as raízes neste caso extraíram água do solo até camadas profundas, em resposta à baixa disponibilidade de água nas camadas mais superficiais. Resultados da aplicação do modelo CERES-Maize em diferentes épocas de semeadura, indicaram que um atraso na semeadura, desde primeiro de fevereiro até o 15 de abril, sob condições de sequeiro, determinou um decréscimo no rendimento, da ordem

de $45 \%$ para os quatro híbridos estudados. Resultados da análise de predição de rendimento, mostrou que uma estimativa adequada pode ser realizada com aproximadamente 45 dias de antecedência à data de colheita para os quatro híbridos avaliados. Simulações conduzidas com o modelo CERES-Maize para 86 anos de dados climáticos evidenciaram que para semeaduras simuladas em 15 de março, para um mesmo nível de probabilidade, nos anos "El Niño" o rendimento médio tende a ser maior do que durante anos "La Niña" e neutros.

\section{Summary}

In recent years maize has become one of the main alternative crops for the Autumn-Winter growing season in the State of São Paulo, Brazil. Water deficits, suboptimum temperatures and low sunshine hours are common problems experienced during the growing season. To analyze the impact of variable climatic conditions on yield, simulation models can be used. The Cropping System Model CSM-CERESMaize, included in the Decision Support System for Agrotechnology Transfer (DSSAT) 
v4.0, was parameterized and then evaluated using data from three field experiments conducted in Piracicaba, SP, Brazil. Data for model evaluation came from three field experiments with completely randomized design with four hybrids AG9010 (very-short season), DAS CO32 and Exceler (short season) and DKB 333B (normal season), and with 3 replications for the 2001 experiment and 4 replications for the two experiments conducted during 2002. The CSM-CERES-Maize was used to conduct seasonal analyses and to estimate yield variability of maize grown off-season, using historical weather data. The relation between simulated yield and the ENSO (El Niño Southern Oscillation) phenomenon was studied. The evaluation of the CSM-CERES-Maize, showed that the model is effective in simulating phenology and grain yield, since values of RMSE were less than $5 \%$. Whereas some deviation where observed in yield components, mainly for very-short season maturity hybrid, AG9010, in which were obtained the lowest values of Agreement index (d) for kernel number per square meter and for kernel weight. LAI and dry matter accumulation was reasonably well predicted with CSM-CERES-Maize for the short and normal-season hybrids. However, for very-short-season hybrid an underestimation of LAI and dry matter accumulation was evident. For example, for this hybrid under irrigated conditions of 2001, the simulated maximum LAI was $2.1 \mathrm{~m}^{2} \mathrm{~m}^{-2}$ and the observed value was $2.7 \mathrm{~m}^{2} \mathrm{~m}^{-2}$. The water balance procedure used by CSMCERES-Maize model simulated the temporal changes in soil water content well. While soil water content under irrigated conditions stayed steady at $40 \mathrm{~cm}$ depth, soil water content under rainfed conditions decreased slowly until $80 \mathrm{~cm}$ depth, suggesting that roots grew until deep layers as a response to the low water availability. The results of the application of the CSM-CERES-Maize model showed that when analyzing different planting dates under rainfed conditions, a delayed sowing date, from February $1^{\text {st }}$ to April $15^{\text {th }}$, determined decrease in yield prediction around $45 \%$ for the four hybrids. Results of yield forecasting analysis showed that an accurate yield forecast could be provided approximately 45 days prior to the harvest date for the four maize hybrids that were analyzed in this study. Simulations conducted with the CSM-CERES-Maize model for 86 years of climate records showed that during years of "El Niño" average yield for the four hybrids was greater than during "La Niña" and neutral years. 


\subsection{Introdução}

Nos últimos anos, o milho "safrinha" tem se tornado uma importante alternativa de cultura para o período de outono-inverno no Estado de São Paulo, o que pode-se constatar pelo incremento na área semeada com essa cultura, que passou de 284.000 ha em 1992 a 341.000 ha no ano de 2001 (Tsunechiro, 2002). O milho "safrinha", apesar de ser uma cultura atrativa aos produtores, é de alto risco devido principalmente às condições climáticas bastante variáveis durante esse período do ano.

O Estado de São Paulo é caracterizado por abundantes precipitações entre os meses de outubro e fevereiro, cerca de $80 \%$ do total anual, e precipitações mais reduzidas e variáveis entre os meses de março e setembro. Com isso, as deficiências hídricas ocorrem com muita freqüência no período da "safrinha". Além disso, as temperaturas sub-ótimas e a baixa insolação também são comuns durante essa estação de crescimento, o que é responsável por considerável redução no rendimento potencial do milho. Usualmente, o milho "safrinha" segue uma cultura de verão (soja) e é beneficiada pelas precipitações que ocorrem no final do mês de fevereiro e março. No entanto, atrasos na semeadura podem ocorrer devido ao insuficiente conteúdo de água no solo para o estabelecimento da cultura ou quando ocorrem atrasos na semeadura da cultura na estação anterior. Atrasos na semeadura aumentam o risco de ocorrência de geadas na cultura (Caramori et al., 1999). Neste sentido, o conhecimento adequado da variabilidade climática pode ajudar na precaução e conduzir a melhores resultados ambientais, sociais e econômicos (Ropelewiski e Jones, 1987, Lemos et al., 2002).

Um outro aspecto a ser considerado no entendimento da influência das condições ambientais sobre o rendimento do milho "safrinha" é o fenômeno do El Niño Oscilação Sul (ENOS), haja visto que este altera o padrão das condições do tempo quando se manifesta. Na região Amazônica e no nordeste do Brasil, menores índices pluviométricos tem sido observados durante os anos "El Niño" (Aceituno, 1988; Marengo, 1992; Uvo, 1998). Em contraposição, na região Sul do Brasil o efeito é oposto ao observado nas regiões Nordeste e Norte, com anomalias de precipitação positivas, ou seja, com chuvas acima dos índices normais, enquanto que secas podem ocorrer nessa 
região quando o fenômeno "La Niña” se manifesta (Ropelewski e Halpert, 1989; Grimm et al., 1996, Grimm et al., 2000). Dada a estreita relação entre a precipitação e o rendimento do milho, entende-se que o conhecimento dos efeitos dos fenômenos "El Niño" e "La Niña" nos regimes pluviométricos e térmicos de uma região contribui à tomada de decisões adequadas para se minimizar os riscos do impacto climático na cultura, no caso a do milho "safrinha".

Apesar de diversas pesquisas estarem sendo realizadas com a cultura do milho "safrinha" em grande parte do Brasil nos últimos anos, falta de informação técnica para entender o impacto das condições climáticas no rendimento tem sido relatadas (Oliveira e Fornasieri, 1999). Nesse sentido, os modelos de simulação são uma ferramenta bastante útil, podendo predizer a variabilidade do rendimento devido as condições ambientais (Gungula et al., 2003). Modelos matemáticos que simulam o crescimento, desenvolvimento e rendimento das culturas variam em complexidade, podendo ser desde simples equações para simular unidades térmicas e requerimentos de horas de frio, para calcular o desenvolvimento, até modelos mais complexos que predizem o rendimento através da simulação do crescimento e desenvolvimento e das interações com o balanço de água e nitrogênio no solo (Hoogenboom, 2003). Normalmente, os efeitos de longo prazo podem ser analisados pelos modelos de modo a se determinar os principais fatores de risco e com isso se identificar as práticas de manejo que os reduzam (Muchow et al., 1991; Thornton et al., 1995; Faria et al., 1997; Chipanshi et al., 1997; Chipanshi et al., 1999; Cavero et al., 2000; Rinaldi, 2001; Heinemann, 2001, Ben Nouna, et al., 2003; Nijbroek, et al., 2003).

O Sistema de Suporte à Tomada de Decisão para a Transferência de Agrotecnologia (DSSAT) é um sistema abrangente para avaliar opções de manejo em função das condições ambientais (Tsuji et al., 1994; Gijsman et al., 2002; Hoogenboom et al., 2003; Jones et al., 2003). Muitas das aplicações dos modelos do DSSAT têm sido para estudar diferentes práticas de manejo, incluindo fertilizantes, irrigação, manejo de pragas e estudos em locais específicos. Um aspecto importante de muitos desses estudos é que eles consideram a influência das condições climáticas no crescimento, desenvolvimento e rendimento da cultura, por meio da interação complexa com o solo e 
com as práticas de manejo (Jones et al., 2003). O modelo CERES-Maize, incluído no programa DSSAT v4.0 (Hoogenboom et al., 2003; Jones et al., 2003), é orientado a processos, dinâmico e específico para cada cultura. Mais detalhes da descrição do modelo CERES-Maize podem ser encontradas em Jones e Kiniry (1986) e Ritchie et al. (1998). Aplicações dos modelos para predição de rendimento podem ser feitas previamente, antes da semeadura ou mesmo durante o desenvolvimento da cultura. Em ambos os casos, a informação obtida de predição de rendimento pode ser utilizada pelos agricultores ou por agências governamentais para o planejamento de políticas agrícolas (Hoogenboom, 2000). Para simulações conduzidas durante a estação de crescimento para predição de rendimento, usualmente utilizam-se os dados de clima mais recentes (Duchon, 1986; Thornton et al., 1997). O que é interessante, tanto para um tomador de decisão como para um agricultor, é se conhecer a mudança na distribuição projetada do rendimento ao passo que os dados climáticos da estação de crescimento são incorporados à simulação, em substituição aos dados normais. Quanto mais próximo do final da estação de crescimento, menor o número de dias com clima incerto (dados normais), o que leva à estimativa mais precisa do rendimento, com a variância tendendo a se aproximar de zero (Thornton et al., 1997). Em caso de se ter uma estimativa segura do rendimento da cultura antes da colheita, os tomadores de decisão poderiam tomar as medidas necessárias para lidar com déficits ou excessos de produção. No Brasil, a predição de rendimento é conduzida mediante formulários preenchidos pelos agricultores, porém essa metodologia é cara e com um considerável grau de subjetividade e incerteza (Fontana et al., 2000). No entanto, atualmente se esta implementando um projeto denominado Geosafras no Brasil, que visa reduzir incertezas para melhorar a gestão de estoques e de escoamento da produção, por meio de informações mais precisas sobre volumes, épocas e localizações da produção (Gomes, 2004).

Buscando-se integrar os diversos aspectos relacionados à estimativa do rendimento do milho "safrinha", o presente trabalho teve por objetivos: 1) avaliar o modelo CERES-Maize em relação a sua capacidade para simular o crescimento e rendimento de quatro híbridos de milho de diferentes ciclos na "safrinha", em 
Piracicaba, Estado de São Paulo, Brasil; 2) avaliar o procedimento de cálculo do balanço hídrico pelo modelo CERES-maize, em relação à sua habilidade para simular o conteúdo de água no solo em diferentes camadas sob condições de irrigação e de sequeiro; 3) aplicar o modelo CERES-Maize para análise sazonal, visando o estudo do efeito de diferentes épocas de semeadura para milho na "safrinha", sob condições de irrigação e de sequeiro e para previsão de rendimento sob condições de sequeiro; e 4) analisar o efeito dos fenômenos "El Niño" e "La Niña" no rendimento da cultura do milho "safrinha”, semeada em Piracicaba, Estado de São Paulo, Brasil.

\subsection{Materiais e métodos}

\subsubsection{Experimentos de campo}

Três experimentos de campo envolvendo quatro híbridos de milho foram conduzidos na "Escola Superior de Agricultura Luiz de Queiroz" da Universidade de São Paulo, em Piracicaba (-22 $43^{\circ}$ latitude, $-47^{\circ} 25^{\prime}$ longitude, $580 \mathrm{~m}$ acima do nível do mar), Estado de São Paulo, Brasil, durante os anos 2001 e 2002. O clima da região, de acordo com a clasificacao de Koppen, é Cwa, subtropical com verão chuvoso e inverno seco. O solo da área experimental é classificado como Terra Roxa Estruturada.

Um experimento foi conduzido durante o ano 2001 sob condições de irrigação, e mais dois experimentos foram conduzidos em 2002, um sob condições de irrigação e outro de sequeiro. Todos os experimentos tiveram o delineamento de blocos completos ao acaso, com três repetições no experimento conduzido em 2001 e quatro repetições nos experimentos conduzidos em 2002. Os híbridos de milho usados neste estudo foram: AG9010 (ciclo super-precoce), DAS CO32 e Exceler (ciclo precoce) e DKB 333B (ciclo normal). As datas de semeadura foram 15 de março para o experimento conduzido em 2001 e 13 de março para os experimentos do ano 2002. 


\subsubsection{Avaliações biométricas}

A fenologia do milho foi registrada para cada parcela em base diária. O florescimento feminino foi registrado quando os estigmas foram visíveis na espiga em $50 \%$ das plantas de cada parcela. A maturidade fisiológica foi determinada regularmente amostrando-se duas espigas por parcela para se identificar a presença do ponto preto na base dos grãos.

A área foliar e a altura das plantas foram medidas a cada 18 dias aproximadamente em três plantas por parcela nos três experimentos. Para determinação da área de folhas e do acúmulo de matéria seca utilizaram-se métodos destrutivos. A área de folhas foi estimada como a soma do produto do comprimento e da máxima largura, medidos manualmente em cada folha. Tal soma foi posteriormente multiplicada pelo fator de conversão 0,75 , de acordo ao procedimento descrito por McKee (1964). O Índice de Área Foliar (IAF) foi calculado dividindo-se a soma da área de folhas $\left(\mathrm{m}^{2}\right)$ pela superfície de solo disponível para cada planta $\left(\mathrm{m}^{2}\right)$.

A matéria seca da parte aérea foi medida a intervalos aproximados de 18 dias, começando-se 21 dias após a semeadura até a colheita, com a amostragem de $1 \mathrm{~m}$ linear nas fileiras centrais das parcelas. As áreas amostradas foram espaçadas para se evitar os efeitos das amostragens prévias. As amostras foram acondicionadas em estufa à temperatura de $70^{\circ} \mathrm{C}$ até atingir massa constante.

A colheita foi realizada manualmente em 8 metros lineares nas duas fileiras centrais das parcelas. O rendimento foi corrigido para $0 \%$ de umidade. O número de grãos por espiga foi contado em 12 espigas por repetição. A massa de grãos foi obtida da média da massa de 8 grupos de 100 grãos, e corrigida a $0 \%$ de umidade e estimada a massa de um grão.

\subsubsection{Dados de clima e solo}

Os dados de temperatura máxima e mínima do ar, precipitação e radiação solar foram obtidos pela estação meteorológica automática da Escola Superior de Agricultura “Luiz de Queiroz” da Universidade de São Paulo, localizada a cerca de $1 \mathrm{~km}$ da área dos 
experimentos de campo. O solo da área experimental, classificado como Terra Roxa Estruturada, é caracterizado por possuir um elevado conteúdo de argila (acima de 60\%). Para caracterizar individualmente os solos dos três experimentos de campo, 12 amostras foram coletadas e analisadas para cada experimento, a diferentes profundidades: 20, 40, 60 e $100 \mathrm{~cm}$. As seguintes análises foram conduzidas: textura, densidade e propriedades químicas. Para a caracterização das propriedades hidráulicas do solo nos experimentos conduzidos durante o ano de 2002, 12 amostras de solo a 20 e $50 \mathrm{~cm}$ de profundidade foram coletadas e analisadas para se conhecer a capacidade de retenção de água a 10 diferentes valores de retenção, desde zero (saturação) até $15.000 \mathrm{~cm}$ de coluna de água (ponto de murcha).

A equação proposta por Van Genuchten (1980) foi ajustada com base nos resultados obtidos do conteúdo de água retido a diferentes tensões. Para tanto, foram conduzidas análises de regressão com o software Soil Water Retention Curve (DouradoNeto et al., 2001), para a determinação dos coeficientes empíricos da equação 1:

$$
\theta=\theta r+\frac{\theta s-\theta r}{\left[1+(\alpha \tau)^{n}\right]^{m}}
$$

em que: $\theta$ é a umidade atual $\left(\mathrm{cm}^{3} \mathrm{~cm}^{-3}\right), \theta r$ a umidade residual $\left(\mathrm{cm}^{3} \mathrm{~cm}^{-3}\right), \theta s$ a umidade na saturação $\left(\mathrm{cm}^{3} \mathrm{~cm}^{-3}\right), \tau$ a tensão da água $(\mathrm{cm})$ no solo, e $\alpha, m$ e $n$ são os coeficientes empíricos do modelo.

O conteúdo de água foi monitorado a cada dois dias com três baterias de tensiômetros instalados a quatro diferentes profundidades: 20, 40, 55 e $70 \mathrm{~cm}$. As leituras dos tensiômetros foram transformadas em conteúdo de água no solo utilizandose a curva de retenção de água no solo, ajustando-se a equação 1 aos dados observados. Nos experimentos conduzidos em 2002, o conteúdo de água no solo foi determinado em três épocas, empregando-se o método gravimétrico, sendo uma antes da semeadura e duas durante o período vegetativo (aos 20 e 41 dias após a semeadura). 


\subsubsection{Teste do modelo CERES-Maize}

O modelo CERES-Maize, incluído no programa DSSAT v4.0, foi calibrado e testado para as condições experimentais deste trabalho, conforme recomendação de Hoogenboom et al. (2003) e Jones et al. (2003). Para a calibração, os coeficientes genéticos foram obtidos em seqüência, começando-se com os parâmetros referentes à fenologia, seguidos pelos parâmetros de crescimento da cultura. Essa ordem foi requerida por causa da dependência dos parâmetros de crescimento em relação aos parâmetros fenológicos (Jones et al., 1987; Hoogenboom et al., 1992). Procedimento iterativo (Hunt et al., 1993) foi utilizado para selecionar o valor mais apropriado para cada parâmetro fenológico e, posteriormente, de crescimento. As datas de emergência, florescimento e maturidade, dados de análise de crescimento, rendimento e componentes do rendimento foram utilizados para calibrar e testar o desempenho do modelo CERESMaize.

O experimento conduzido durante o ano de 2001 foi utilizado para efetuar a calibração do modelo CERES-Maize, enquanto que os experimentos conduzidos durante 2002 foram utilizados como dados independentes para a avaliação.

Datas de fenologia, componentes de rendimento e rendimento em grão foram comparados utilizando-se o Índice "d" de Concordância (Willmott et al., 1985), o qual é definido como:

$$
\mathrm{d}=1-\left[\frac{\sum_{\mathrm{i}=1}^{\mathrm{N}}(\mathrm{Pi}-\mathrm{Oi})^{2}}{\sum_{\mathrm{i}=1}^{\mathrm{N}}\left(\left|\mathrm{P}^{\prime} \mathrm{i}\right|+\left|\mathrm{O}^{\prime} \mathrm{i}\right|\right)^{2}}\right]
$$

em que: N é o número de observações, Pi é o valor estimado, Oi é o valor observado, P'i $=\mathrm{Pi}-\mathrm{M}$ e O $\mathrm{O}=\mathrm{Oi}-\mathrm{M}$, sendo $\mathrm{M}$ a média da variável observada .

De acordo com o índice estatístico d, quanto mais próximo da unidade, melhor a concordância entre as duas variáveis comparadas e vice-versa.

A porcentagem de desvio (PD) foi calculada considerando-se a diferença entre os valores medidos e observados (para o rendimento e seus componentes), dividindo-se 
esse valor pelos valores observados e multiplicando-se por 100, para convertê-lo em porcentagem. Percentagem de desvios negativos indicam sub-estimativa enquanto que percentagem de desvios positivas indicam super-estimativa. Além disso, o quadrado médio do erro (RMSE) foi calculado de acordo com Loague and Green (1991), utilizando-se a equação 3 .

$$
\mathrm{RMSE}=\sqrt{\frac{\sum_{\mathrm{i}=1}^{\mathrm{N}}(\mathrm{Pi}-\mathrm{Oi})^{2}}{\mathrm{~N}}} * \frac{100}{\mathrm{M}}
$$

em que: Pi e Oi referem-se às variáveis estudadas, dias desde a semeadura ao florescimento feminino, dias desde o florescimento feminino até a maturidade fisiológica, índice de área foliar, acúmulo de matéria seca, rendimento e componentes do rendimento.

RMSE indica a diferença relativa, em \%, entre os valores simulados e observados. A simulação é considerada excelente quando RMSE é menor do que 10\%, boa entre 10 e $20 \%$, aceitável entre 20 e $30 \%$ e pobre quando maior do que $30 \%$ (Jamieson et al., 1991).

Com o objetivo de condensar a quantidade de informações geradas, serão apresentados para a avaliação do balanço de água no solo com o modelo CERES-Maize somente os dados referentes ao híbrido AG9010.

\subsubsection{Avaliações de diferentes épocas de semeadura no rendimento do milho "safrinha"}

A análise sazonal foi conduzida com o modelo CERES-Maize para se estudar os efeitos de diferentes datas de semeadura no rendimento do milho "safrinha". Dois cenários distintos foram simulados, considerando a cultura de milho "safrinha" sob condições de sequeiro e de irrigação. Seis datas de semeadura foram avaliadas: $1^{\circ}$ de fevereiro, 15 de fevereiro, $1^{\circ}$ de março, 15 de março, $1^{\circ}$ de abril e 15 de abril. Foi estimada a probabilidade de se obter rendimentos em diferentes níveis, sob condições de 
sequeiro e de irrigação, para as 6 datas de semeadura. A porcentagem de quebra de rendimento foi também determinada, de acordo com a seguinte equação:

$$
\text { Qr }=\left[1-\left(\frac{\text { Ysequeiro }}{\text { Yirrig }}\right)\right] * 100
$$

em que: Qr é a quebra de rendimento; Ysequeiro é o rendimento sob condições de sequeiro; Yirrig é o rendimento sob condições de irrigação.

\subsubsection{Previsão de rendimento do milho "safrinha"}

O modelo CERES-Maize foi também utilizado para realizar a previsão de rendimento para os quatro híbridos sob estudo. Para as análises de previsão de rendimento foram combinados dados climáticos históricos diários de um período de 25 anos, de Piracicaba, Estado de São Paulo, com dados meteorológicos diários, registrados durante o ano de 2002. A cada duas semanas foi conduzida a previsão de rendimento, começando-se em 31 de março de 2002 (17 dias após a semeadura) e prolongando-se até o 31 de julho de 2002. Para a previsão, os dados meteorológicos diários do ano 2002 foram utilizados até a data de realização das estimativas, complementando-se o restante da estação de crescimento com dados climáticos históricos diários da série de 25 anos. Baseados nas práticas agronômicas da região, foram simuladas condições de sequeiro e de baixo uso de fertilizantes. As análises foram conduzidas para cada data de previsão de rendimento e as médias e os desvios padrões do rendimento foram determinados.

\subsubsection{Estudo da influência dos fenômenos El Niño e La Niña no rendimento do milho "safrinha"}

Foi conduzida uma análise mostrando-se a influência das alterações climáticas ocorridas nos anos com os fenômenos "El Niño" e "La Niña, no rendimento do milho "safrinha" em Piracicaba, SP. Para tanto, identificaram-se os anos com a manifestação 
das fases "El Niño", "La Niña" e "neutro", de acordo com os dados apresentados pelo Centro para Estudos de Predições Oceânicas e Atmosféricas (COAPS, 2003), considerando-se uma série de 86 anos, correspondente à serie histórica de dados meteorológicos de Piracicaba. Análises da temperatura do ar e da precipitação mensal foram conduzidas de acordo com os anos "El Niño", "La Niña” e neutros. O modelo CERES-Maize foi utilizado para simular o rendimento sob condições de sequeiro, utilizando-se os 86 anos de dados para a região de Piracicaba. A data de semeadura simulada foi a de 15 de março para cada ano da série histórica.

\subsection{Resultados e discussão}

\subsubsection{Teste do modelo CERES-Maize}

Com os coeficientes genéticos calibrados o modelo CERES-Maize prediz o crescimento e desenvolvimento do milho. Os coeficientes genéticos P1, P2 e P5 definem a fenologia da cultura enquanto que os G2 e G3 estão relacionados com a definição do rendimento em grão. P1 representa o tempo térmico desde a emergência até o final da fase juvenil durante a qual a planta não apresenta resposta ao fotoperíodo. Foi encontrado que o híbrido AG9010 de ciclo super-precoce teve os valores mais baixos para o coeficiente genético P1 $\left(196^{\circ} \mathrm{Cd}\right)$, enquanto que para o híbrido de ciclo normal DKB 333B foi obtido o maior valor, $263^{\circ} \mathrm{Cd}$ (Tabela 1). O coeficiente genético $\mathrm{P} 2$ foi considerado igual a 0,5 para os quatro híbridos, porém não foi simulado resposta ao fotoperíodo devido à duração do dia durante a época da "safrinha" ser menor do que o fotoperíodo critico (12,5 horas). O coeficiente genético P5 está relacionado com o tempo térmico desde o florescimento feminino até a maturidade fisiológica, variando entre $747,8^{\circ} \mathrm{Cd}$ para o híbrido DAS CO32 e $842^{\circ} \mathrm{Cd}$ para o híbrido DKB 333B. O coeficiente genético G2 está relacionado com o número máximo possível de grãos por planta. G2 variou entre 940 e 990 nos quatro híbridos. Para o G3, foi encontrado que o híbrido DKB 333B teve o menor valor $\left(4,4 \mathrm{mg} \mathrm{d}^{-1}\right)$ e o híbrido AG9010 o maior valor 
(5,2 $\left.\mathrm{mg} \mathrm{d}^{-1}\right)$ de enchimento de grão. O filocron (PHY) é o intervalo em tempo térmico (graus-dia) entre a aparição de folhas subseqüentes; foi fixado como a média dos valores observados em cada híbrido nos três experimentos, que variou de $42,3{ }^{\circ} \mathrm{Cd}$ a $46,6^{\circ} \mathrm{Cd}$ para os híbridos Exceler e AG9010, respectivamente.

Tabela 1 - Coeficientes genéticos requeridos pelo modelo CERES-Maize para os quatro híbridos de milho estudados.

\begin{tabular}{lcccccc}
\hline Híbrido & P1 & P2 & P5 & G2 & G3 & PHY \\
\hline AG9010 & 196,0 & 0,5 & 758,0 & 990,0 & 5,20 & 46,6 \\
DKB 333B & 263,0 & 0,5 & 842,0 & 940,0 & 4,40 & 44,1 \\
DAS CO32 & 240,0 & 0,5 & 747,8 & 990,0 & 5,00 & 43,4 \\
EXCELER & 232,0 & 0,5 & 766,0 & 990,0 & 5,15 & 42,3 \\
\hline
\end{tabular}

P1: Tempo térmico da emergência até o final da fase juvenil (expresso em graus-dia acima da temperatura basal de $8^{\circ} \mathrm{C}$ ) durante o qual a planta não apresenta resposta ao fotoperíodo; P2: Extensão do atraso no desenvolvimento (expresso em dias) por cada hora de incremento no fotoperíodo acima do qual o desenvolvimento procede à taxa máxima (o qual é considerado ser 12,5 horas); P5: Tempo térmico entre o florescimento feminino e a maturidade fisiológica (expresso em graus-dias acima da temperatura basal de $8^{\circ} \mathrm{C}$ ); G2: Número máximo de grãos por planta; G3: Taxa de enchimento do grão durante a fase linear sob condições ótimas ( $\mathrm{mg} \mathrm{dia}^{-1}$ ); PHY: Intervalo correspondente ao filocron em tempo térmico (graus-dia) entre a aparição de folhas subseqüentes (Hoogenboom et al., 1994).

O número de dias observados desde a emergência até o florescimento feminino para os quatro híbridos nos três experimentos e os valores simulados para essa fase com o modelo CERES-Maize foram similares em magnitude. Na Figura 1a pode se observar que os valores observados e simulados de dias desde a emergência até o florescimento feminino se situam próximo da linha de valores iguais. Um elevado coeficiente de determinação foi encontrado entre os valores simulados e observados, com a declividade da reta da regressão estatisticamente diferente de zero e o intercepto igual a zero ao nível $\mathrm{P} \leq 0,05$. Além disso, o Índice de Concordância (d) foi elevado $(0,99)$, e o RMSE expresso em porcentagem foi baixo $(1,6 \%)$, mostrando a habilidade do modelo CERESMaize em simular a fenologia nos quatro híbridos nos três experimentos. 

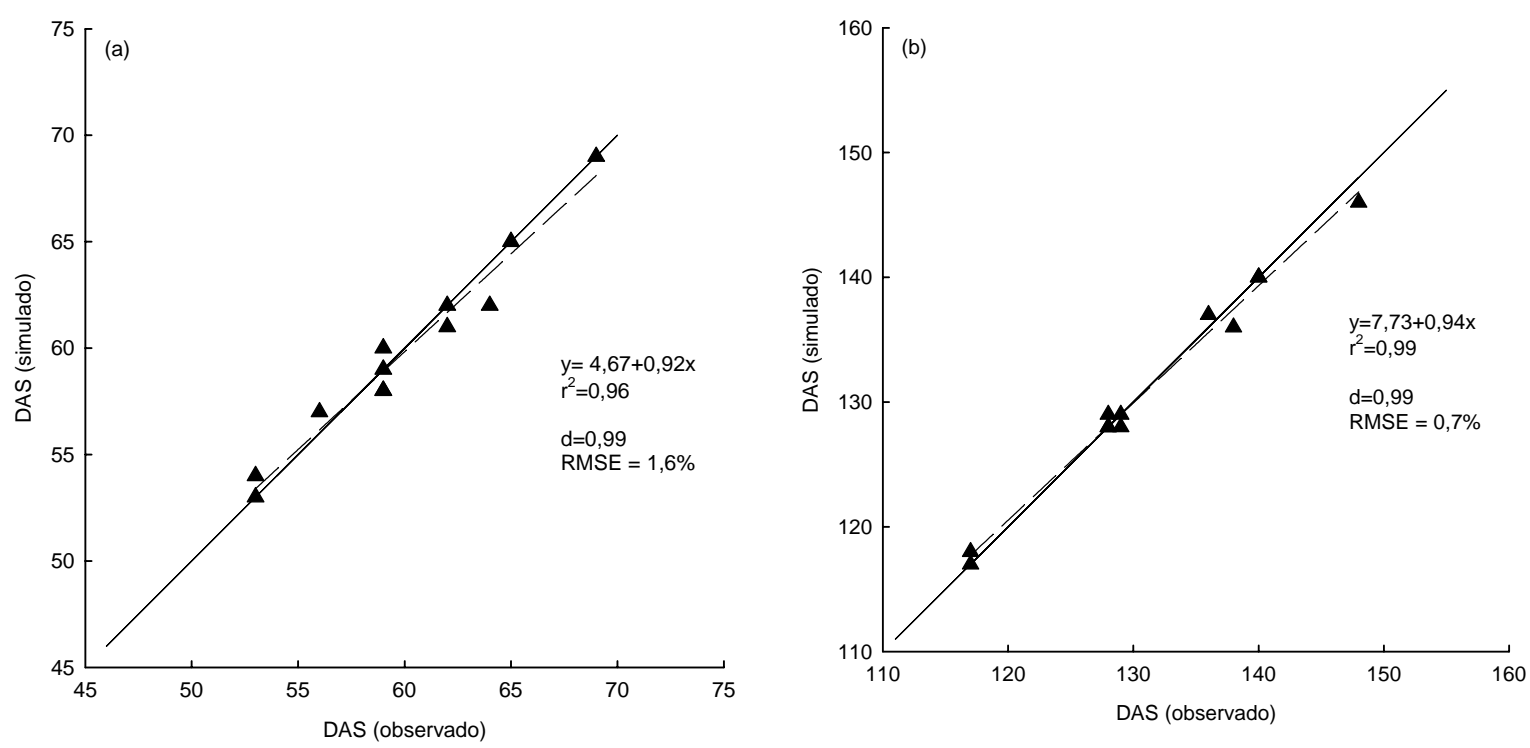

Figura 1 - Relação entre o número de dias observados e simulados desde a semeadura até o florescimento feminino (a) e desde o florescimento feminino até a maturidade fisiológica (b), para os quatro híbridos de milho semeados em Piracicaba, Estado de São Paulo, Brasil. (DAS = dias após a semeadura).

O modelo CERES-Maize simulou o período desde a semeadura até a maturidade fisiológica com precisão, sendo o índice de concordância (d) bastante elevado $(0,99)$ e o RMSE extremamente baixo $(0,7 \%)$. Ainda, foi obtido um elevado coeficiente de determinação $\left(r^{2}=0,99\right)$ entre os valores observados e simulados, com uma declividade estatisticamente diferente de zero e o intercepto igual a zero, confirmando a adequada estimativa realizada com o modelo CERES-Maize para o período desde a semeadura até a maturidade fisiológica (Figura 1b).

Uma adequada predição do IAF também foi observada até 40 dias após a semeadura para os híbridos AG9010, DKB 333B e DAS CO32 sob condições de irrigação no ano 2001. No entanto, após 40 dias da semeadura uma sub-estimativa do IAF foi evidente, como apresentado na Figura 2. Os desvios padrões observados (barras verticais) para o híbrido Exceler abrangeram os valores simulados pelo modelo CERESMaize durante a estação de crescimento. Além disso, o maior Índice de Concordância (d) 
e o menor RMSE obtido no híbrido Exceler, indicou que o modelo CERES-Maize foi capaz de predizer o IAF para este híbrido com adequada precisão. Por outro lado, o híbrido AG9010 teve desvios padrões dos valores observados que não abrangeram os valores simulados nas três últimas amostragens. $\mathrm{O}$ menor valor do Índice de Concordância $(d=0,92)$ foi obtido no híbrido AG9010. A simulação foi considerada boa para os híbridos DKB 333B, DAS CO32 e Exceler, pois o RMSE esteve entre 10 e 20\%. O híbrido AG9010, de ciclo super-precoce, teve o menor valor máximo de IAF observado $(2,7)$ enquanto que os outros três híbridos tiveram o máximo IAF maior do que 3,5. Similarmente, o máximo IAF simulado pelo modelo CERES-Maize foi de 2,1 para o híbrido AG9010 e próximo de $3 \mathrm{~m}^{2} \mathrm{~m}^{-2}$ para os outros três híbridos.

No teste do modelo com dados do experimento realizado sob irrigação no ano de 2002, o IAF foi adequadamente estimado nos híbridos DKB 333B, DAS CO32 e Exceler, enquanto que para o híbrido de ciclo super-precoce AG9010 houve subestimativa, principalmente depois de 50 dias após a semeadura (Figura 3). O menor valor de Índice de Concordância (d) e o maior valor de RMSE foram obtidos entre os valores observados e simulados de IAF no híbrido AG9010. O máximo IAF simulado para o híbrido AG9010 foi de $2,2 \mathrm{~m}^{2} \mathrm{~m}^{-2}$ e o máximo IAF observado foi de $2,7 \mathrm{~m}^{2} \mathrm{~m}^{-2}$. Para os outros três híbridos o máximo IAF simulado foi próximo de $3,2 \mathrm{~m}^{2} \mathrm{~m}^{-2}$, no entanto os valores observados de IAF foram maiores nos híbridos DKB 333B e DAS CO32 e menores que esse valor no híbrido Exceler.

O teste conduzido com dados independentes, do experimento realizado no ano 2002 sob condições de sequeiro, mostrou que houve uma adequada estimativa do IAF para os híbridos DKB 333B, DAS CO32 e Exceler, com Índices de Concordância variando de 0,98 a 0,99 e RMSE entre 10 e 20\%. Entretanto, uma subestimativa do IAF foi observada no híbrido AG9010, principalmente nas três últimas amostragens, nas quais as barras verticais ou desvios padrões dos valores observados não abrangeram os valores de IAF simulados pelo modelo (Figura 4). O máximo IAF observado no híbrido AG9010 foi de $2,8 \mathrm{~m}^{2} \mathrm{~m}^{-2}$ e o máximo IAF simulado foi de $2,25 \mathrm{~m}^{2} \mathrm{~m}^{-2}$.

Foi observada uma subestimativa do acúmulo de matéria seca entre os dias 50 e 90 após a semeadura no experimento sob irrigação do ano 2001 para o híbrido AG9010 
(Figura 2). O Índice de Concordância (d) variou entre 0,95 no híbrido Exceler e 0,97 nos híbridos DAS CO32 e DKB 333B. O RMSE foi maior do que 20\% para os quatro híbridos indicando que a simulação do acúmulo de matéria seca foi aceitável. O máximo valor de acúmulo de matéria seca observado variou entre $12.200 \mathrm{~kg} \mathrm{ha}^{-1}$ nos híbridos AG9010 e Exceler e $13.700 \mathrm{~kg} \mathrm{ha}^{-1}$ para o híbrido DKB 333B. As barras dos desvios padrões dos valores observados na colheita abrangeram os valores simulados pelo modelo CERES-Maize nos híbridos AG9010, DKB 333B e DAS CO32.
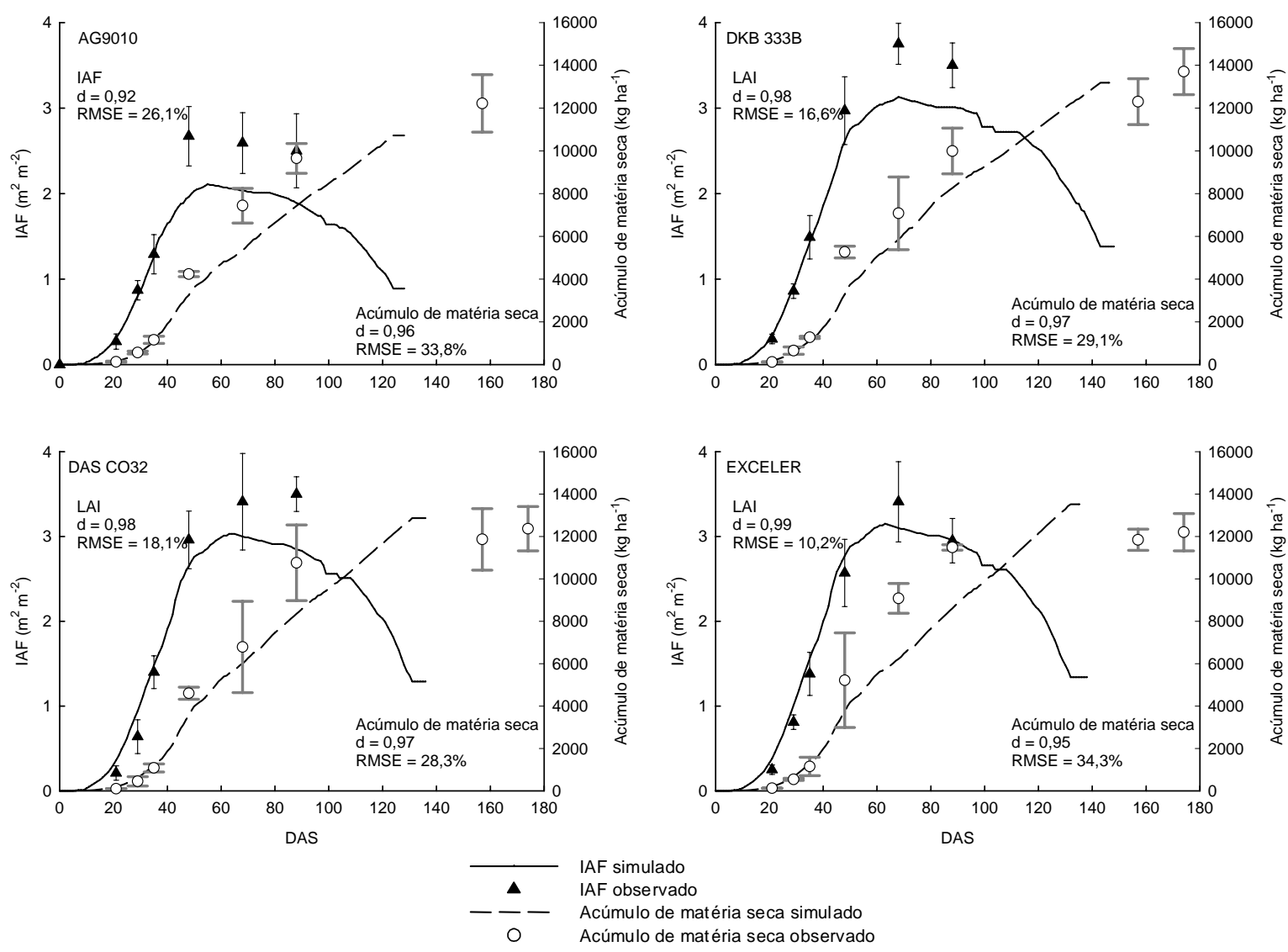

Figura 2 - Valores observados e simulados de IAF e do acúmulo de matéria seca para quatro híbridos de milho semeados em Piracicaba, Estado de São Paulo, Brasil, durante a "safrinha" de 2001, sob condições de irrigação. As barras verticais indicam o desvio padrão das medidas. 
O teste do modelo com dados independentes para acúmulo de matéria seca para os híbridos sob condições de irrigação no ano 2002, indicou que a estimativa foi aceitável, haja visto que os valores de RMSE foram maiores do que $20 \%$ nos quatro híbridos (Figura 3). Paralelamente, foram obtidos valores do Índice de Concordância (d), entre 0,94 e 0,97 para os quatro híbridos. As barras dos desvios dos valores observados abrangeram os valores de matéria seca simulados pelo modelo CERES-Maize nos quatro híbridos.
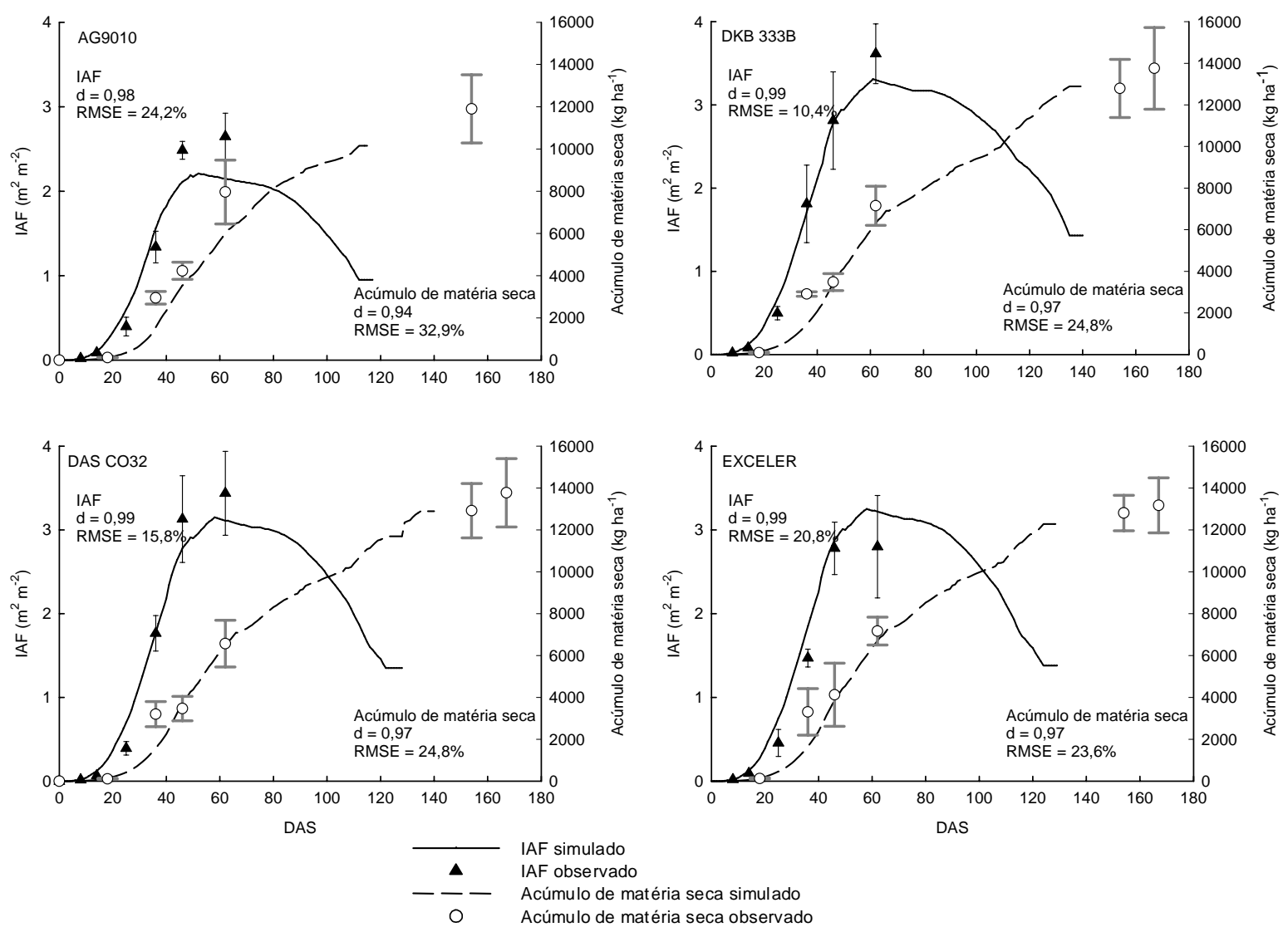

Figura 3 - Valores observados e simulados de IAF e do acúmulo de matéria seca para quatro híbridos de milho semeados em Piracicaba, Estado de São Paulo, Brasil, durante a "safrinha" de 2002, sob condições de irrigação. As barras verticais indicam o desvio padrão das medidas. 
Adequada estimativa do acúmulo de matéria seca foi obtida nas condições de sequeiro do ano de 2002, nos híbridos AG9010, DKB 333B e Exceler, com o Índice de Concordância variando entre 0,98 e 0,99, e RMSE entre 10 e 20\% (Figura 4). Para o híbrido DAS CO32 obteve-se uma aceitável estimativa do acúmulo de matéria seca pelo modelo, com RMSE maior do que 20\% e Índice de Concordância (d) de 0,98. Para esse híbrido, assim como para o híbrido Exceler, as barras dos desvios dos valores observados de matéria seca na colheita não abrangeram os valores simulados pelo modelo. O modelo CERES-Maize subestimou a matéria seca na colheita em ambos híbridos. Para o híbrido AG9010, (ciclo super-precoce), foi observado o menor valor de acúmulo máximo de matéria seca na colheita, com $9.000 \mathrm{~kg} \mathrm{ha}^{-1}$, enquanto que o híbrido DKB 333B teve $10.000 \mathrm{~kg} \mathrm{ha}^{-1}$ e os híbridos DAS CO32 e Exceler apresentaram valores superiores aos $12.000 \mathrm{~kg} \mathrm{ha}^{-1}$.
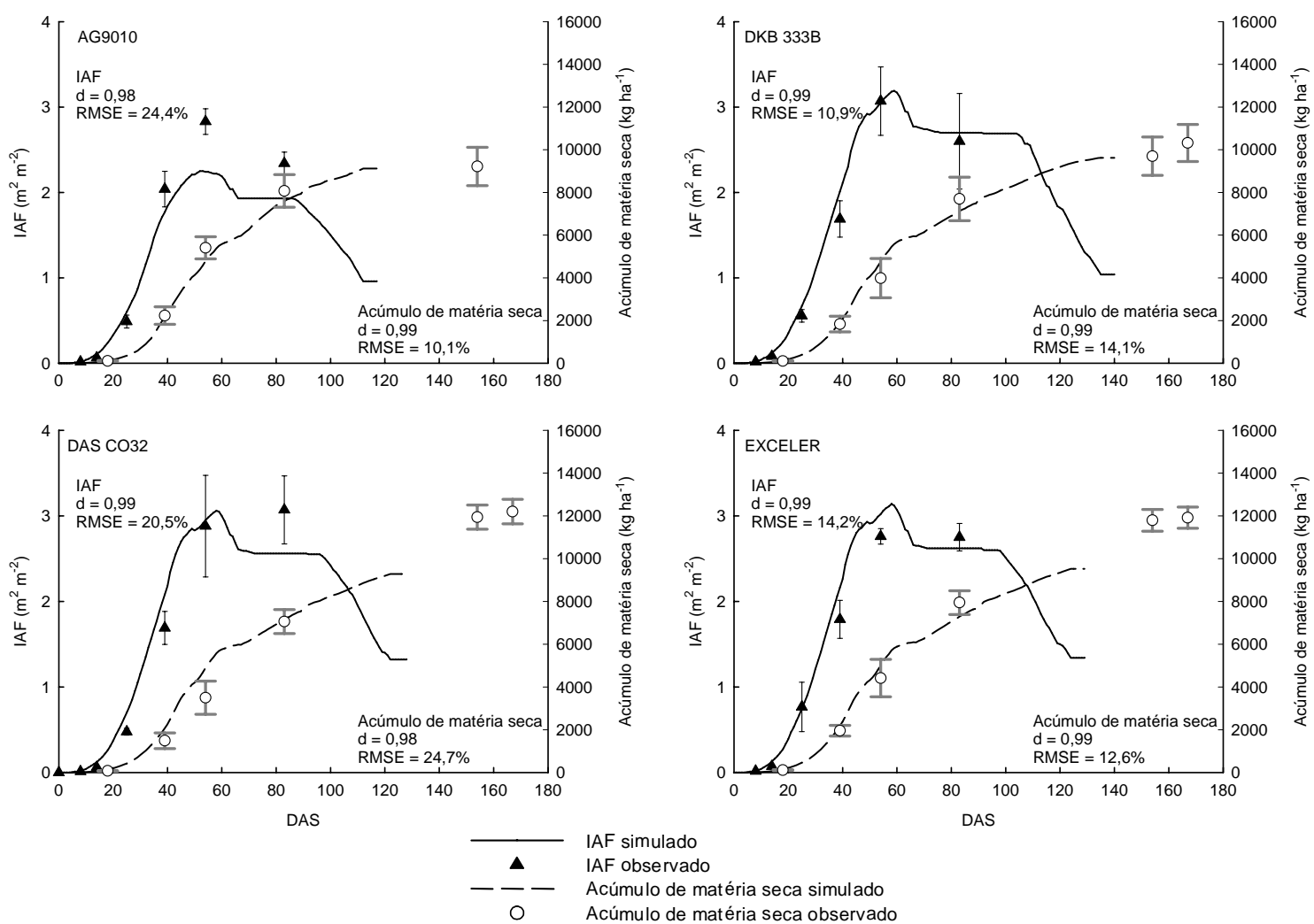

Figura 4 - Valores observados e simulados de IAF e do acúmulo de matéria seca para quatro híbridos de milho semeados em Piracicaba, Estado de São Paulo, Brasil, durante a "safrinha" de 2002, sob condições de sequeiro. As barras verticais indicam o desvio padrão das medidas. 
O rendimento foi adequadamente simulado pelo modelo CERES-Maize nos híbridos estudados. Para os híbridos DKB 333B e DAS CO32 os valores observados e simulados foram bastante similares e a porcentagem de desvio da estimativa variou entre $-3.1 \%$ e $6.0 \%$ (Tabela 2 ). Ainda os índices d foram elevados $(0,98$ e 0,99$)$ e os valores de RMSE foram menores do que 5\%. Para os híbridos AG9010 e Exceler, a estimativa foi considerada boa, com RMSE menores do que 10 . O menor valor de $d(0,84)$ foi obtido para o híbrido de ciclo super-precoce AG9010.

Tabela 2 - Valores médios dos rendimentos observados e simulados com o modelo CERES-Maize para quatro híbridos de milho, semeados na "safrinha" dos anos de 2001 e 2002, em Piracicaba, SP, Brasil.

\begin{tabular}{llccccc}
\hline Híbrido & Experimento & Simulado & Observado & PD & RMSE & d \\
& & \multicolumn{2}{c}{ kg ha $^{-1}$} & (\%) & (\%) & \\
AG9010 & Irrigado 2001 & 4.932 & 5.028 & $-1,9$ & & \\
& Irrigado 2002 & 4.924 & 4.986 & $-1,2$ & 5,7 & 0,84 \\
& Sequeiro 2002 & 4.499 & 4.044 & 11,3 & & \\
DKB 333B & Irrigado 2001 & 5.623 & 5.801 & $-3,1$ & & \\
& Irrigado 2002 & 5.446 & 5.139 & 6,0 & 4,2 & 0,98 \\
& Sequeiro 2002 & 3.895 & 3.823 & 1,9 & & \\
DAS CO32 & Irrigado 2001 & 5.668 & 5.684 & $-0,3$ & & \\
& Irrigado 2002 & 5.159 & 5.047 & 2,2 & 1,4 & 0,99 \\
& Sequeiro 2002 & 4.153 & 4.109 & 1,1 & & \\
Exceler & Irrigado 2001 & 6.160 & 5.863 & 5,1 & & \\
& Irrigado 2002 & 5.504 & 5.306 & 3,7 & 6,8 & 0,99 \\
& Sequeiro 2002 & 4.337 & 4.859 & $-10,7$ & & \\
\hline
\end{tabular}

$\mathrm{PD}=$ Desvios percentuais - valores negativos indicam subestimativa enquanto que valores positivos indicam superestimativa.

$\mathrm{O}$ número de grãos por metro quadrado teve porcentagens de desvio entre os valores observados e estimados menores do que $\pm 8 \%$ nos híbridos DKB $333 \mathrm{~B}$ e DAS CO32. Para os híbridos mencionados os valores de RMSE foram menores de $6 \%$ e os 
Índices de Concordância foram iguais a 0,84 (Tabela 3). Porém, para o híbrido AG9010, PD variou entre - $12,8 \%$ e 21,2\% indicando que o modelo CERES-Maize não conseguiu simular adequadamente o número de grãos por metro quadrado nesse híbrido. Foram observadas subestimativas nos híbridos DAS CO32 e Exceler, indicadas pelos valores negativos de PD (\%).

Tabela 3 - Valores médios de número de grãos por metro quadrado observados e simulados com o modelo CERES-Maize para quatro híbridos de milho semeados na "safrinha" dos anos de 2001 e 2002, em Piracicaba, SP, Brasil.

\begin{tabular}{lllcccc}
\hline Híbrido & Experimento & $\begin{array}{c}\text { Simulado } \\
\text { Número de grãos }\end{array}$ & $\begin{array}{c}\text { Observado } \\
\text { (\%) }\end{array}$ & $\begin{array}{c}\text { PD } \\
\text { (\%) }\end{array}$ & RMSE \\
\hline AG9010 & Irrigado 2001 & 1910 & 2191 & $-12,8$ & & \\
& Irrigado 2002 & 2339 & 2318 & 0,9 & 12,8 & 0,49 \\
& Sequeiro 2002 & 2183 & 1801 & 21,2 & & \\
DKB 333B & Irrigado 2001 & 2283 & 2366 & $-3,5$ & & \\
& Irrigado 2002 & 2213 & 2078 & 6,5 & 5,9 & 0,84 \\
& Sequeiro 2002 & 1869 & 2028 & $-7,8$ & & \\
DAS CO32 & Irrigado 2001 & 2208 & 2362 & $-6,5$ & & \\
& Irrigado 2002 & 2165 & 2308 & $-6,2$ & 5,9 & 0,84 \\
& Sequeiro 2002 & 1916 & 2011 & $-4,7$ & & \\
Exceler & Irrigado 2001 & 2361 & 2622 & $-10,0$ & & \\
& Irrigado 2002 & 2233 & 2286 & $-2,3$ & 9,6 & 0,74 \\
& Sequeiro 2002 & 1862 & 2152 & $-13,5$ & & \\
\hline PD = Desvios percentuais - valores negativos indicam subestimativa enquanto que \\
valores positivos indicam superestimativa.
\end{tabular}


O desvio percentual das estimativas para a massa de um grão variou entre $-1,3 \%$ e 3,4\% para os híbridos DAS CO32 e Exceler (Tabela 4). Já para o híbrido AG9010 o PD variou entre -10,3\% e 7,1\%. A massa de um grão foi simulada pelo modelo CERESMaize com exatidão nos híbridos DKB 333B, DAS CO32 e Exceler, obtendo-se valores de RMSE menores do que 5\%. O Índice de Concordância variou entre 0,90 e 0,96 pra esses híbridos reafirmando o bom desempenho do modelo CERES-Maize para simular a massa de grãos em três dos quatro híbridos analisados.

Tabela 4 - Valores médios de massa de grãos observados e simulados com o modelo CERES-Maize para quatro híbridos de milho semados na "safrinha" dos anos de 2001 e 2002, em Piracicaba, SP, Brasil.

\begin{tabular}{|c|c|c|c|c|c|c|}
\hline Híbrido & Experimento & $\begin{array}{r}\text { Simulado } \\
\text { mg }\end{array}$ & $\begin{array}{l}\text { Observado } \\
\text { rão }^{-1}\end{array}$ & $\begin{array}{l}\text { PD } \\
(\%)\end{array}$ & $\begin{array}{c}\text { RMSE } \\
\text { (\%) }\end{array}$ & d \\
\hline \multirow[t]{3}{*}{ AG9010 } & Irrigado 2001 & 258 & 241 & 7,1 & \multirow{3}{*}{8,8} & \multirow{3}{*}{0,49} \\
\hline & Irrigado 2002 & 210 & 231 & $-9,1$ & & \\
\hline & Sequeiro 2002 & 208 & 232 & $-10,3$ & & \\
\hline \multirow[t]{3}{*}{ DKB 333B } & Irrigado 2001 & 255 & 252 & 1,2 & \multirow{3}{*}{3,4} & \multirow{3}{*}{0,94} \\
\hline & Irrigado 2002 & 252 & 251 & 0,4 & & \\
\hline & Sequeiro 2002 & 211 & 225 & $-6,2$ & & \\
\hline \multirow[t]{3}{*}{ DAS CO32 } & Irrigado 2001 & 248 & 247 & 0,4 & \multirow{3}{*}{1,5} & \multirow{3}{*}{0,96} \\
\hline & Irrigado 2002 & 233 & 228 & 2,2 & & \\
\hline & Sequeiro 2002 & 225 & 228 & $-1,3$ & & \\
\hline \multirow[t]{3}{*}{ Exceler } & Irrigado 2001 & 261 & 255 & 2,4 & \multirow{3}{*}{2,5} & \multirow{3}{*}{0,90} \\
\hline & Irrigado 2002 & 246 & 238 & 3,4 & & \\
\hline & Sequeiro 2002 & 236 & 238 & $-0,8$ & & \\
\hline
\end{tabular}




\subsubsection{Conteúdo de água no solo}

O conteúdo de água do solo na saturação para o solo da área experimental, considerado argiloso, classificado como Terra Roxa Estruturada, para as condições do experimento do ano 2002, foi de $0,53 \mathrm{~cm}^{3} \mathrm{~cm}^{-3}$, na capacidade de campo foi de $0,34 \mathrm{~cm}^{3}$ $\mathrm{cm}^{-3}$ e no ponto de murcha foi de $0,28 \mathrm{~cm}^{3} \mathrm{~cm}^{-3}$. Valores similares foram encontrados no experimento conduzido sob condições de irrigação no ano 2001, dada a proximidade das áreas experimentais. O experimento sob condições de sequeiro do ano 2002 foi localizado numa área adjacente também aos experimentos sob irrigação, porém, com algumas diferenças na sua textura e nas propriedades físicas e hídricas. Assim, o solo do experimento sob condições de sequeiro apresentou menor conteúdo de argila $(60 \%)$ do que o solo sob condições de irrigação (65\%), na camada superior. Para o experimento sob sequeiro, a camada superior do solo apresentou densidade global de $0,93 \mathrm{~g} \mathrm{~cm}^{-3}$, enquanto que para o experimento irrigado esse valor foi de $1,23 \mathrm{~g} \mathrm{~cm}^{-3}$. Para o solo do experimento sob sequeiro, o valor da umidade no ponto de saturação foi de $0,46 \mathrm{~cm}^{3} \mathrm{~cm}^{-}$ ${ }^{3}$, na capacidade de campo de $0,28 \mathrm{~cm}^{3} \mathrm{~cm}^{-3}$ e no ponto de murcha de $0,18 \mathrm{~cm}^{3} \mathrm{~cm}^{-3}$.

As leituras dos tensiômetros no experimento sob irrigação no ano 2002 indicaram que o conteúdo de água no solo foi adequado no perfil do solo, confirmando a disponibilidade de água para a cultura ao longo da estação de crescimento, já que o conteúdo de água no solo foi mantido próximo da capacidade de campo nas diferentes camadas (Figura 5). Uma considerável variação no conteúdo de água no solo foi observada até $40 \mathrm{~cm}$ de profundidade, indicando que o consumo de água pelo sistema radicular não foi além dessa profundidade. A explicação mais provável das diferenças encontradas entre as leituras dos tensiômetros e o conteúdo de água no solo simulado pelo DSSAT deve-se ao fato de que a rotina do DSSAT é baseada no balanço de água no solo (Ritchie, 1998), ou seja, não se baseia no potencial de água no solo. Apesar de terem sido feitas poucas amostragens da umidade do solo com o método gravimétrico, foram observadas tendências similares às leituras efetuadas com os tensiômetros. 

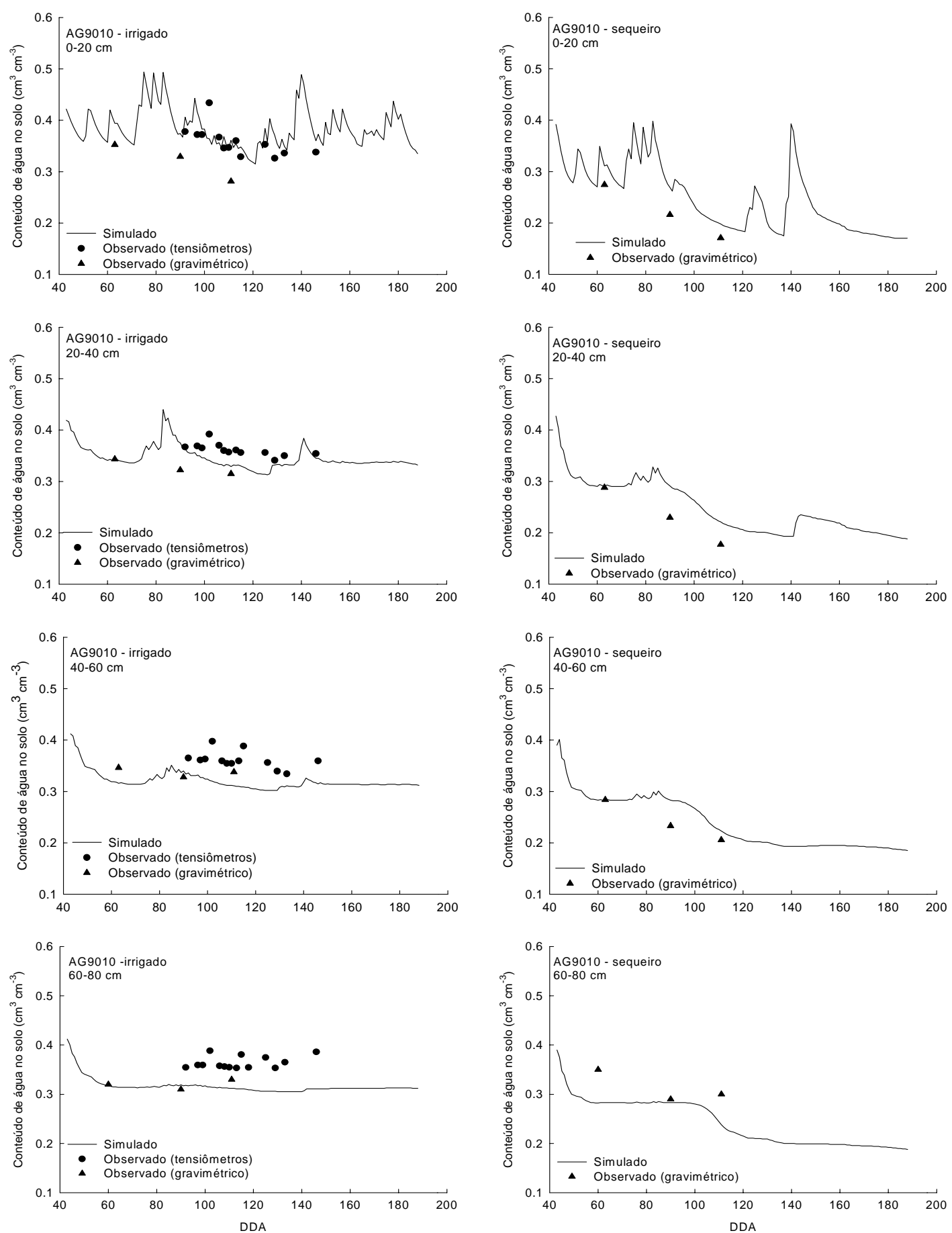

Figura 5 - Valores observados e simulados do conteúdo de água no solo cultivado com o híbrido AG9010 durante a "safrinha" do ano de 2002, em Piracicaba, Estado de São Paulo, Brasil, sob condições de irrigação e de sequeiro. (DDA = dia do ano). 
A variação temporal do conteúdo de água no solo no experimento sob condições de sequeiro mostrou algumas diferenças quando comparada à observada no experimento conduzido sob irrigação. Os tensiômetros instalados na camada de $0-20 \mathrm{~cm}$ foram rapidamente desligados devido à elevada tensão de água no solo e seqüencialmente aqueles a 20-40, 40-60 e $75 \mathrm{~cm}$ de profundidade. Os valores observados de conteúdo de água no solo obtidos pelo método gravimétrico e o conteúdo de água no solo simulado pelo modelo CERES-Maize tiveram uma tendência similar. Tanto os valores de conteúdo de água no solo observados como os simulados pelo DSSAT evidenciaram que o consumo de água ocorreu até camadas mais profundas do solo $(80 \mathrm{~cm}$ de profundidade).

Enquanto que o conteúdo de água sob condições de irrigação se manteve estável até $40 \mathrm{~cm}$ de profundidade, o conteúdo de água no solo sob condições de sequeiro decresceu lentamente, indicando ter havido uma clara resposta da cultura à limitação de água no solo.

Houveram algumas diferenças em conteúdo de água no solo medido com o método gravimétrico e os resultados da transformação das leituras dos tensiômetros. Essas diferenças podem ser explicadas em parte pela variabilidade espacial das propriedades do solo e também pelos erros experimentais associados aos tensiômetros e às amostragens do solo.

\subsubsection{Uso do modelo CERES-Maize para avaliação de diferentes épocas de semeadura}

\subsubsection{Condições de sequeiro}

Os resultados da análise sazonal conduzida com o modelo CERES-Maize para condições de sequeiro evidenciam que para a primeira data de semeadura $\left(1^{\circ}\right.$ de fevereiro) em $20 \%$ dos anos o rendimento foi maior do que $7.000 \mathrm{~kg} \mathrm{ha}^{-1}$, enquanto que em $50 \%$ dos anos o rendimento simulado foi maior do que $6.000 \mathrm{~kg} \mathrm{ha}^{-1}$ (Figura 6), para todos os híbridos. 
Para a data de semeadura de 15 de fevereiro, não houveram maiores diferenças entre os rendimentos simulados para os quatro híbridos. Em $80 \%$ dos anos, o rendimento foi menor do que $4.000 \mathrm{~kg} \mathrm{ha}^{-1}$ e em $20 \%$ dos anos, o rendimento foi maior do que 7.000 $\mathrm{kg} \mathrm{ha}^{-1}$.
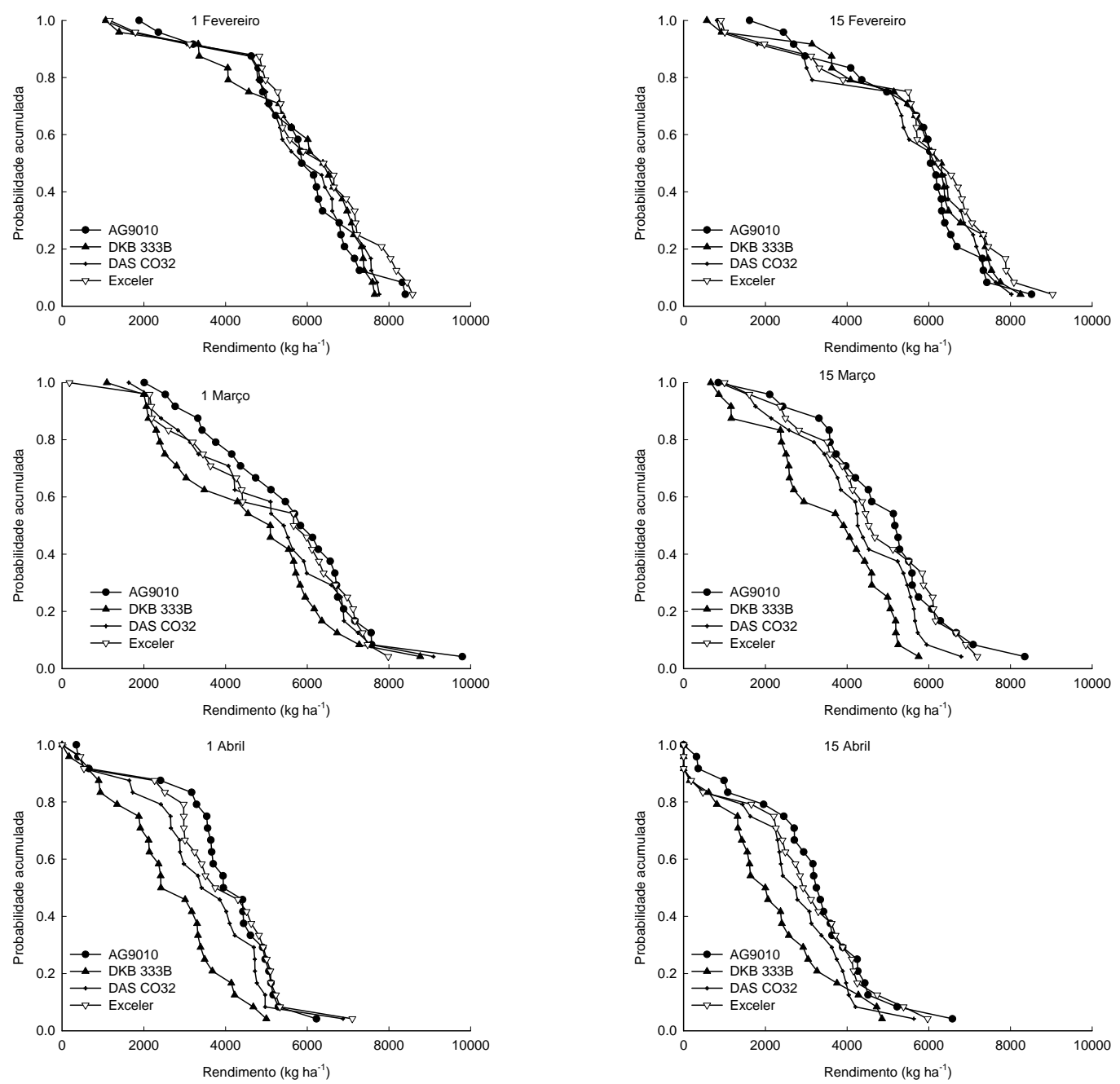

Figura 6 - Probabilidade acumulada do rendimento simulado para os quatro híbridos de milho semeados na "safrinha", sob condições de sequeiro, em Piracicaba, Estado de São Paulo, Brasil.

Para as semeaduras mais tardias, o rendimento simulado apresentou decréscimos em relação às semeaduras mais precoces. Além disso, os diferentes híbridos tiveram resposta diferenciada em relação ao atraso na data de semeadura. Para as datas de 
semeadura de $1^{\circ}$ de abril, em $20 \%$ dos anos o rendimento esteve entre 3.600 e $5.000 \mathrm{~kg}$ $\mathrm{ha}^{-1}$ e em $80 \%$ dos anos o rendimento foi menor do que $3.600 \mathrm{~kg} \mathrm{ha}^{-1}$ para o híbrido AG9010 (super-precoce) e menor do que $1.100 \mathrm{~kg} \mathrm{ha}^{-1}$ para o híbrido DKB 333B (ciclo normal). Para os híbridos de ciclo curto, DAS CO32 e Exceler foram simulados valores intermediários de rendimento, por exemplo, o rendimento simulado em $20 \%$ dos anos esteve entre 4.800 e $5.000 \mathrm{~kg} \mathrm{ha}^{-1}$ e para $80 \%$ dos anos o rendimento foi menor do que 2.500 e $3.000 \mathrm{~kg} \mathrm{ha}^{-1}$, respectivamente.

Para a data de semeadura de 15 de abril, em $20 \%$ dos anos, o rendimento esteve entre 3.300 e $4.200 \mathrm{~kg} \mathrm{ha}^{-1}$ e em $80 \%$ dos anos o rendimento foi inferior a $800 \mathrm{~kg} \mathrm{ha}^{-1}$ para o híbrido de ciclo normal DKB 333B e inferior a $2.100 \mathrm{~kg} \mathrm{ha}^{-1}$ para o híbrido de ciclo super-precoce AG9010. Em 50\% dos anos o rendimento esteve entre 2.100 e 3.300 $\mathrm{kg} \mathrm{ha}^{-1}$ respectivamente para os híbridos DKB 333B e AG9010.

Para as condições de sequeiro, quanto mais tarde a semeadura, menor foi o rendimento simulado nos quatro híbridos de milho. Por exemplo, para o híbrido de ciclo super-precoce AG9010 o rendimento médio foi de $5.800 \mathrm{~kg} \mathrm{ha}^{-1}$ para a primeira data de semeadura ( $1^{\mathrm{o}}$ de fevereiro) e $3.000 \mathrm{~kg} \mathrm{ha}^{-1}$ para a última data de semeadura. Na última data de semeadura, o menor rendimento médio simulado dos quatro híbridos foi obtido para o híbrido de ciclo normal DKB 333B (2.000 $\left.\mathrm{kg} \mathrm{ha}^{-1}\right)$, evidenciando a menor adaptação desse híbrido em épocas de semeadura tardias.

\subsubsection{Condições de irrigação}

O modelo CERES-Maize simulou, sob condições irrigadas, para a primeira data de semeadura ( $1^{\circ}$ de fevereiro) em $80 \%$ dos anos rendimento inferior a $6.000 \mathrm{~kg} \mathrm{ha}^{-1}$, em $20 \%$ dos anos o rendimento foi maior do que $7.500 \mathrm{~kg} \mathrm{ha}^{-1}$ e em $50 \%$ dos anos o rendimento foi superior aos $6.800 \mathrm{~kg} \mathrm{ha}^{-1}$ (Figura 7). Os quatro híbridos não apresentaram diferenças consideráveis sob condições irrigadas, sugerindo que as condições ambientais, principalmente disponibilidade de água no solo teve uma forte influencia no rendimento. Para a semeadura de $1^{\circ}$ de março, em $80 \%$ dos anos, o rendimento foi menor do que $5.800 \mathrm{~kg} \mathrm{ha}^{-1}$ para o híbrido DKB $333 \mathrm{~B}$ e menor do que 
$6.600 \mathrm{~kg} \mathrm{ha}^{-1}$ para o híbrido Exceler. Em 20\% dos anos o rendimento foi maior do que $7.300 \mathrm{~kg} \mathrm{ha}^{-1}$ para os quatro híbridos. Para a semeadura de $1^{\circ}$ de abril, em 50\% dos anos o rendimento foi maior do que $6.000 \mathrm{~kg} \mathrm{ha}^{-1} \mathrm{e}$ na semeadura de 15 de abril o rendimento foi maior do que $5.500 \mathrm{~kg} \mathrm{ha}^{-1}$ para o mesmo nível de probabilidade (50\%) nos quatro híbridos.
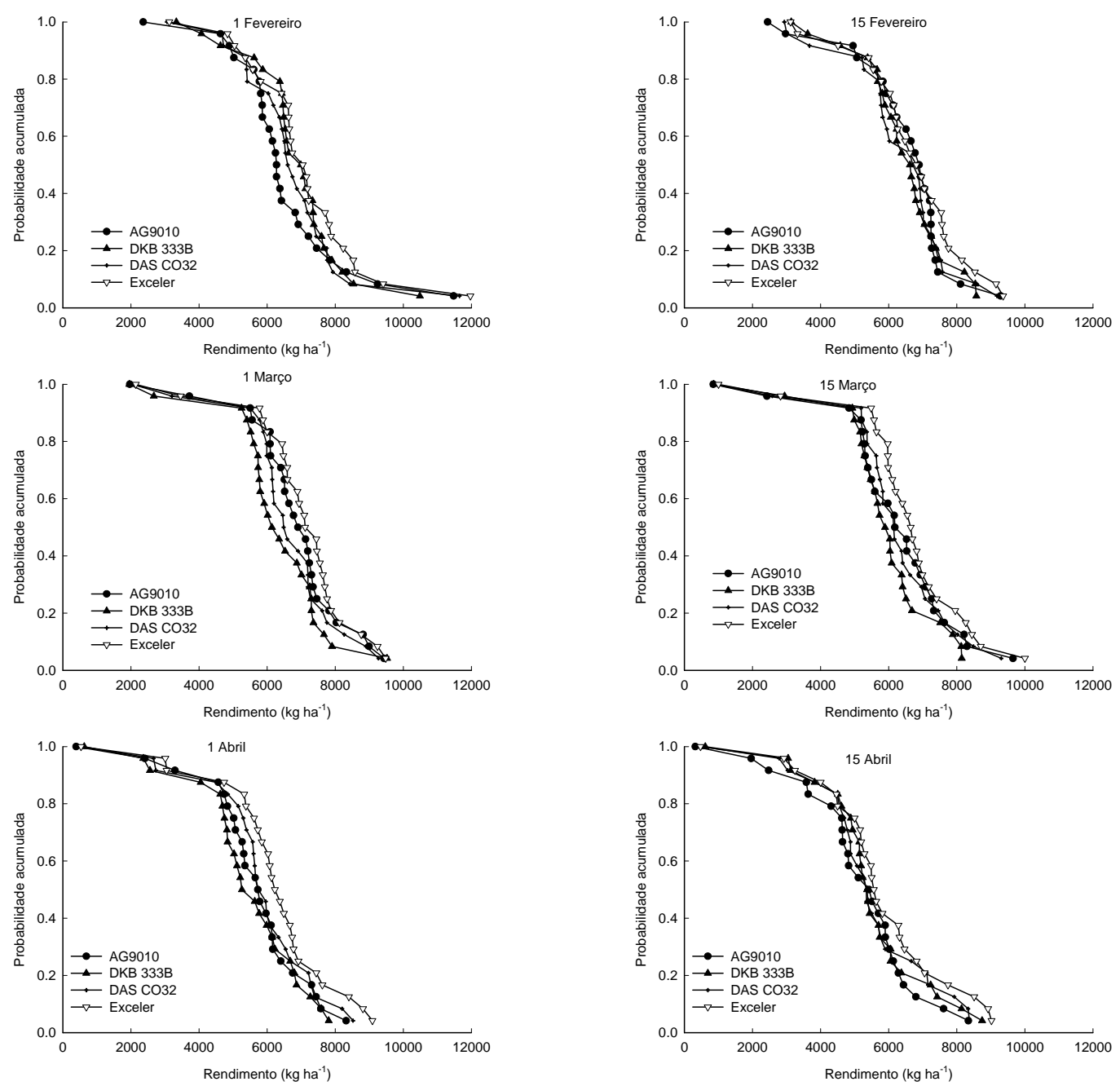

Figura 7 - Probabilidade acumulada do rendimento simulado para os quatro híbridos de milho semeados na "safrinha" sob condições de irrigação, em Piracicaba, Estado de São Paulo, Brasil.

Em geral, quanto mais se atrasou a semeadura, menor foi o rendimento simulado para os quatro híbridos. Para o híbrido de ciclo super-precoce, AG9010, o rendimento 
médio foi de $6.500 \mathrm{~kg} \mathrm{ha}^{-1}$ para a primeira data de semeadura e $5.000 \mathrm{~kg} \mathrm{ha}^{-1}$ para a última data de semeadura. O decréscimo de rendimento observado ao se atrasar a data de semeadura é menos evidente sob condições de irrigação do que sob condições de sequeiro. Esses resultados confirmam a importância da disponibilidade de água para a cultura visando-se obter um adequado nível de rendimento ao se atrasar a semeadura.

A quebra de rendimento, que expressa o decréscimo de rendimento entre condições irrigadas e de sequeiro, variou entre 10 e 18\% para os híbridos AG9010 e DKB 333B, respectivamente, para a primeira data de semeadura, $1^{\circ}$ de fevereiro (Figura 8). Valores similares foram simulados para a segunda data de semeadura (15 de fevereiro). Para as semeaduras de março e de abril, foi simulado um continuo acréscimo no risco de perda de rendimento. Para a última data de semeadura, 15 de abril, a quebra de rendimento variou entre 38 e 60\% para os híbridos AG9010 e DKB 333B respectivamente. Valores intermediários foram encontrados para os demais híbridos. Tais resultados evidenciam o alto risco imposto pelas condições climáticas às semeaduras tardias do milho "safrinha" nas condições do centro do Estado de São Paulo. O híbrido de ciclo normal foi o mais sujeito às condições climáticas adversas incluindo precipitação, temperatura e radiação solar, resultando em maiores prejuízos do que para os híbridos de ciclo curto. Esses resultados estão de acordo com outros trabalhos que destacam que as cultivares de ciclo curto são mais promissórias para o milho cultivado na "safrinha" (Oliveira et al., 1994, Duarte et al., 1994). 


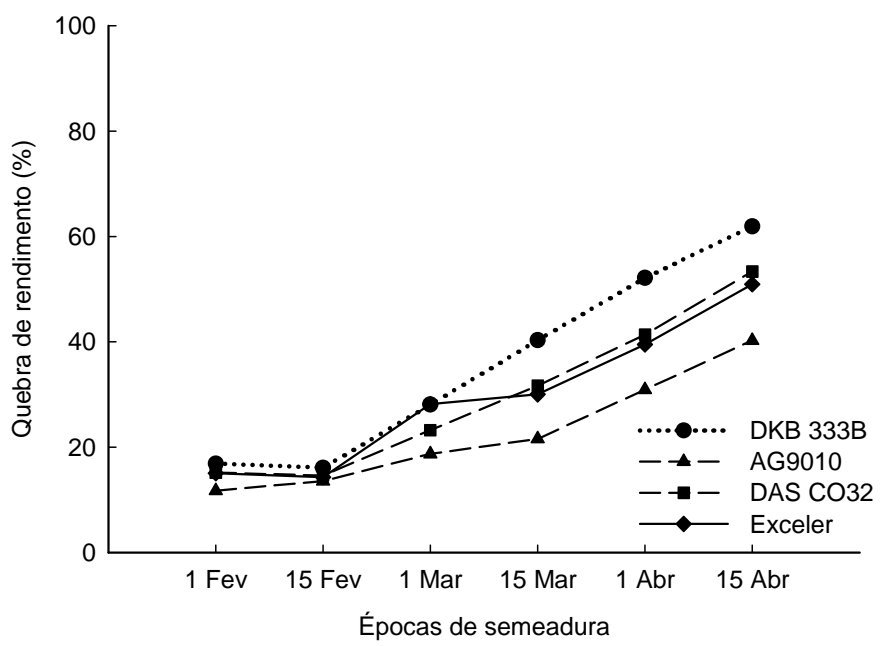

Figura 8 - Quebra de rendimento simulada (\%) em decorrência da deficiência hídrica, para os quatro híbridos de milho semeados na "safrinha", em Piracicaba, Estado de São Paulo, Brasil.

\subsubsection{Uso do modelo CERES-Maize para a previsão de rendimento}

Foi simulada uma alta variabilidade no rendimento nas previsões realizadas no começo da estação de crescimento durante abril e maio, a qual pode ser visualizada nos desvios padrões apresentados na Figura 9. No começo da estação de crescimento foram simulados rendimentos que evidenciam as variações ambientais dos 25 anos simulados, dificultando a predição de rendimento. Ainda, a alta variabilidade do rendimento no começo da estação de crescimento confirma que existe um alto risco associado à cultura de milho "safrinha" sob condições de sequeiro. Quando as simulações foram conduzidas num período com maior proporção de dados meteorológicos do ano 2002, o desvio padrão diminuiu gradativamente para os 4 híbridos estudados. Para o híbrido AG9010, DAS CO32 e Exceler, o rendimento estimado teve desvio padrão próximo de zero em 15 de julho (Figuras 9a, 9c e 9d) enquanto que para o híbrido DKB 333B, de ciclo normal, o desvio padrão foi próximo de zero em 31 de julho (Figura 9b). Assim, para os híbridos de ciclo curto, a previsão do rendimento do milho "safrinha" pode ser conduzida mais cedo do que para os híbridos de ciclo normal. 
Para os quatro híbridos, o erro na previsão do rendimento medido através do desvio padrão foi de $821 \mathrm{~kg} \mathrm{ha}^{-1}$ em 31 de maio e de $296 \mathrm{~kg} \mathrm{ha}^{-1}$ em 30 de junho. Em média, poderia ser efetuada uma previsão precisa do rendimento com 45 dias de antecedência à colheita nos quatro híbridos estudados. Resultados similares têm sido verificados utilizando similar metodologia, quanto mais próximo do final da estação de crescimento e menor o número de dias com clima incerto (dados normais) a estimativa de rendimento é mais precisa, com a variância tendendo a se aproximar de zero (Thornton et al., 1997, Garcia, et al., 2003). 

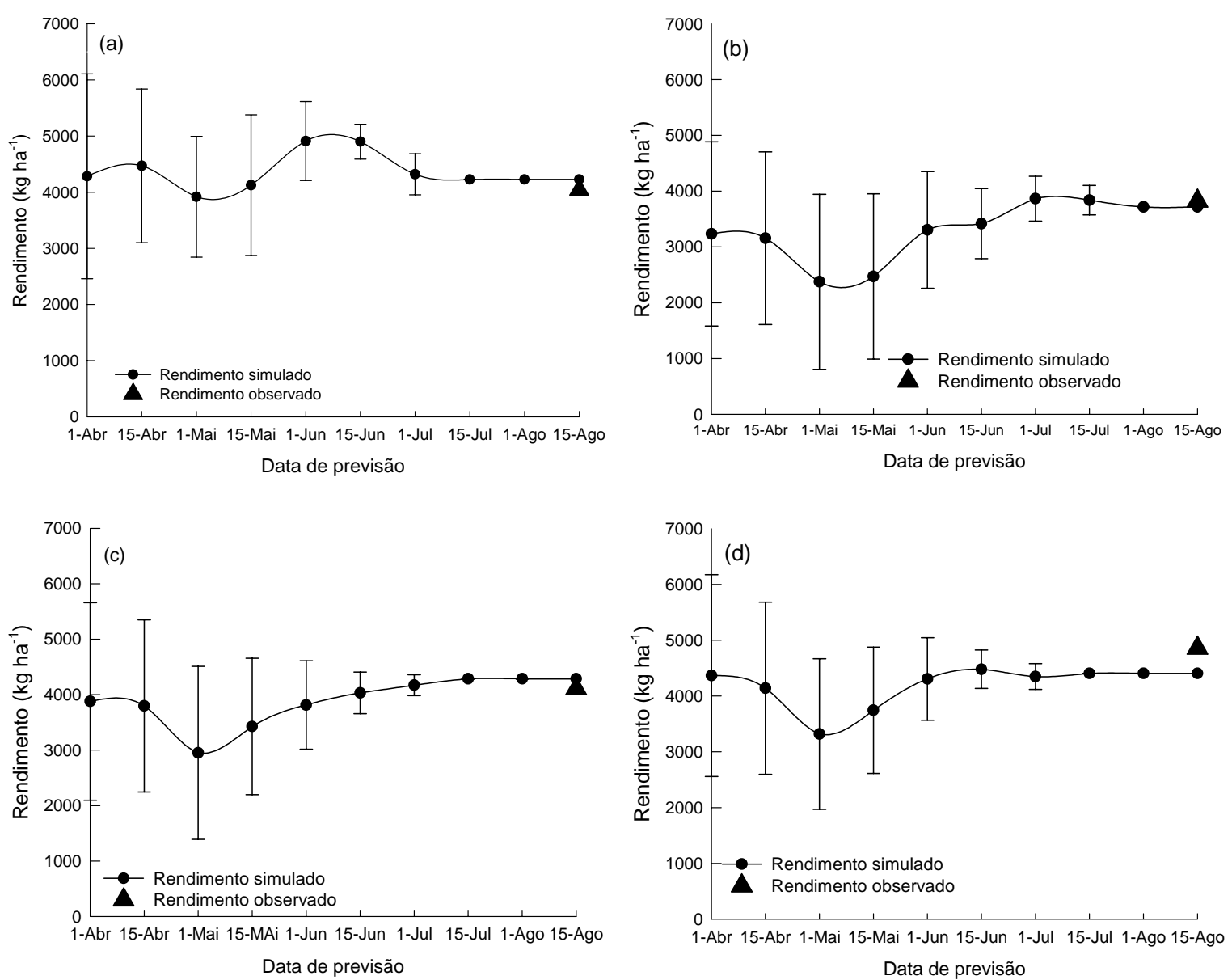

Figura 9 - Rendimento e desvio padrão previstos para a cultura do milho "safrinha" para o ano 2002 em função da combinação de dados climatológicos e dados meteorológicos do ano em questão, na escala diária, utilizando-se o modelo CERES-Maize para os híbridos AG9010 (a), DKB 333B (b), DAS CO32 (c) e Exceler (d).

\subsubsection{Relação entre os fenômenos El Niño e La Niña e o rendimento de milho "safrinha"}

A análise de 86 anos de dados climáticos de Piracicaba, Estado de São Paulo, mostrou que nos meses de abril e maio houve diferenças na média mensal de precipitação entre os anos com episódios dos fenômenos "El Niño", "La Niña" e anos neutros. Durante os anos de "El Niño", as precipitações médias para os meses de abril e 
maio foram respectivamente de 27 e $32 \mathrm{~mm}$ maiores do que durante os anos de "La Niña”. Da mesma forma, as precipitações médias mensais desses meses foram 31 e 40 mm maiores durante os anos de "El Niño" do que em anos neutros. Essas diferenças durante os meses de abril e maio são críticas para a cultura do milho "safrinha", já que neste período do ano normalmente ocorre o florescimento e o começo do enchimento dos grãos, as quais são fases mais criticas do milho à ocorrência de deficiência hídrica. As simulações realizadas com o modelo CERES-Maize para os 86 anos de dados climáticos mostraram que em anos de "El Niño" o rendimento do híbrido AG9010 foi, em média, superior (5.292 $\left.\mathrm{kg} \mathrm{ha}^{-1}\right)$ ao rendimento simulado em anos de "La Niña" (4.870 $\mathrm{kg} \mathrm{ha}^{-1}$ ) e também em anos neutros $\left(3.744 \mathrm{~kg} \mathrm{ha}^{-1}\right)$. A mesma tendência foi observada para o híbrido de ciclo normal, DKB 333B, com maior rendimento médio nos anos de "El Niño" (3.364 kg ha $\left.{ }^{-1}\right)$ e menores nos anos de "La Niña" (2.886 kg ha $\left.{ }^{-1}\right)$ e neutros $\left(2.112 \mathrm{~kg} \mathrm{ha}^{-1}\right)$. A análise de probabilidade acumulada indicou que para os quatro híbridos, em quase todos os níveis de probabilidade, o rendimento simulado foi maior nos anos de "El Niño" do que em anos de "La Niña" e neutros (Figura 10). 

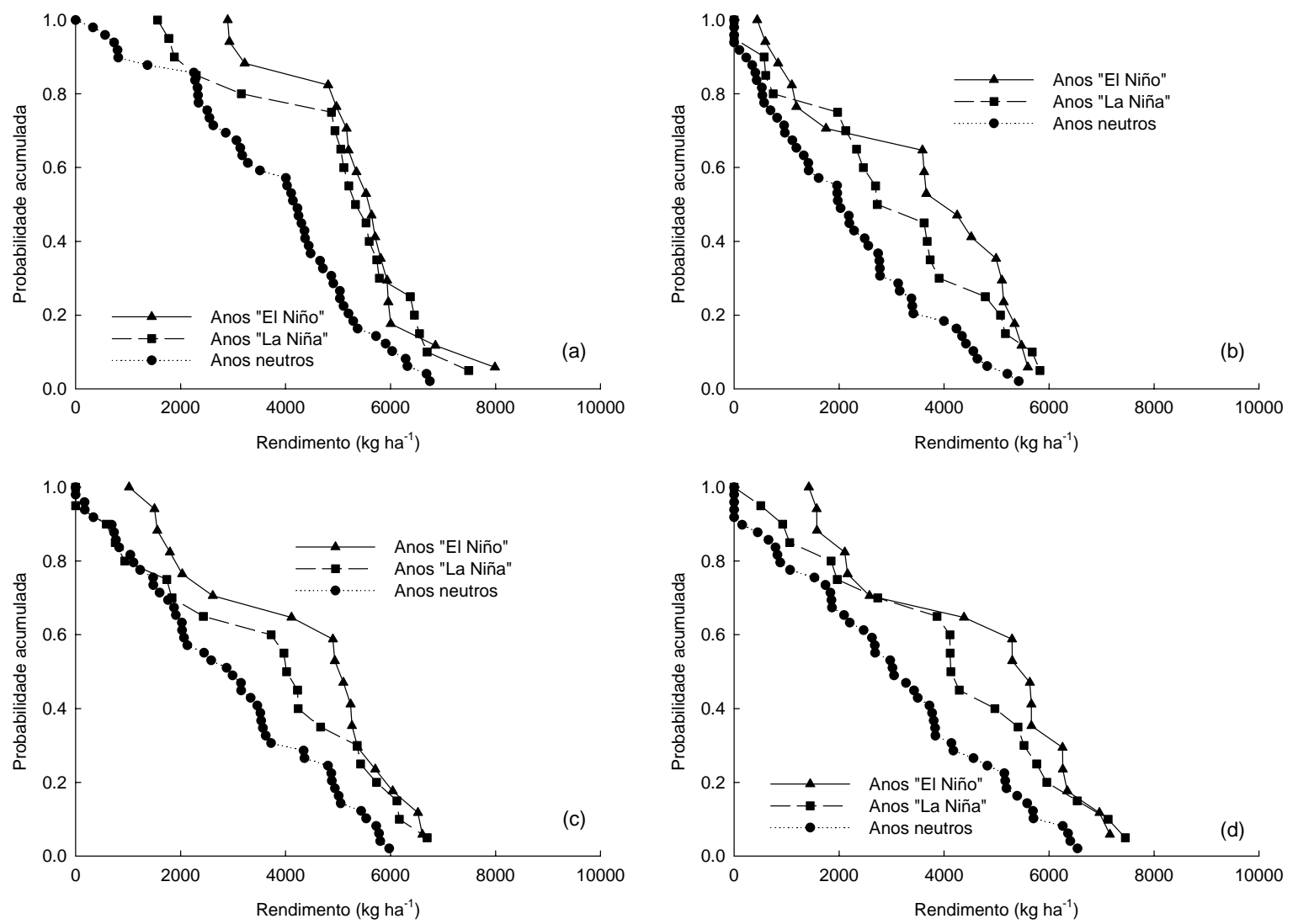

Figura 10 - Probabilidade acumulada de rendimento simulado para os híbridos: (a) A1G9010 (b) DKB 333B, (c) DAS CO32 and (d) Exceler, de milho "safrinha" durante anos de "El Niño", de "La Niña" e neutros em Piracicaba, estado de São Paulo, Brasil.

\subsection{Conclusões}

Baseado nos resultados apresentados pode-se concluir que:

a) o modelo CERES-Maize simulou com adequada precisão a fenologia e o rendimento do milho "safrinha" para as condições de Piracicaba, Estado de São Paulo. O índice de área foliar (IAF) e o acúmulo de matéria seca foi considerado razoavelmente bem estimado com o modelo CERES-Maize para dois híbridos de ciclo curto e um de ciclo normal. No entanto, para o híbrido de ciclo superprecoce AG9010 o IAF e o acúmulo de matéria seca foi subestimado pelo modelo. 
b) uma adequada estimativa do rendimento foi obtida com o modelo CERES-Maize, o que em parte se deveu à boa estimativa do conteúdo de água no solo simulado com o modelo CERES-Maize.

c) em geral, para os dois sistemas de cultivo, sob irrigação e sob sequeiro, quanto mais tardia a semeadura, menor o rendimento do milho "safrinha" simulado para os quatro híbridos. Portanto, recomendasse que as semeaduras da "safrinha" sejam feitas o quanto antes, postergando-as somente quando estritamente necessário.

d) o modelo CERES-Maize mostrou ser uma excelente ferramenta para a previsão do rendimento do milho "safrinha", utilizando-se dados climatológicos combinados aos dados meteorológicos do ano em questão. Esse procedimento permitiu se obter adequada estimativa do rendimento com 45 dias de antecedência à colheita dos quatro híbridos de milho semeados na "safrinha" em Piracicaba, Estado de São Paulo.

e) o fenômenos "El Niño" e "La Niña" tiveram influência sobre o rendimento do milho "safrinha" em Piracicaba, Estado de São Paulo, em decorrência de mudanças nos padrões de precipitação durante os meses de abril e maio. Os rendimentos foram maiores durante os anos de "El Niño" do que em anos de "La Niña”, que por sua vez foram superiores aos rendimentos obtidos para os anos neutros. 


\section{CONCLUSÕES GERAIS}

Os resultados obtidos neste estudo indicaram que:

- O milho "safrinha", sob condições de sequeiro, apresentou em geral, menores valores de IAF, altura de planta e acúmulo de matéria seca do que sob condições de irrigação.

- A cultura submetida a limitação de água no solo teve uma atividade radicular intensa nas camadas mais profundas do solo, sugerindo que um incremento no comprimento das raízes foi a resposta às deficiências hídricas.

- $\quad$ A massa do grão e o número de grãos por metro quadrado foram os componentes mais associados ao rendimento. O híbrido de ciclo normal, DKB 333B, foi o mais afetado pela deficiência hídrica.

- $\quad$ O modelo CERES-Maize simulou com adequada precisão a fenologia e o rendimento do milho "safrinha" para as condições de Piracicaba, no Estado de São Paulo.

- $\quad$ Em geral, para os dois sistemas de cultivo, sob irrigação e sob sequeiro, quanto mais tardia a semeadura, menor o rendimento do milho "safrinha" simulado para os quatro híbridos.

- $\quad$ O modelo CERES-Maize mostrou ser uma excelente ferramenta para a previsão do rendimento do milho "safrinha", utilizando-se dados climatológicos combinados aos dados meteorológicos do ano em questão. Com esse procedimento foi possível se obter adequada estimativa do rendimento com 45 dias de antecedência à colheita nos quatro híbridos de milho semeados na "safrinha" em Piracicaba. 
- $\quad$ Os fenômenos "El Niño" e "La Niña" tiveram influência sobre o rendimento do milho "safrinha" em Piracicaba, em decorrência de mudanças nos padrões de precipitação durante os meses de abril e maio. Os rendimentos foram maiores durante os anos de "El Niño" do que em anos de "La Niña", que por sua vez foram superiores aos rendimentos obtidos para os anos neutros. 


\section{REFERÊNCIAS BIBLIOGRÁFICAS}

ABRECHT D.G.; CARBERRY, P.S. The influence of water deficit prior to tassel initiation on maize growth, development and yield. Field Crops Research, v.31, p.55-69, 1993.

ACEITUNO, P. On the functioning of the Southern Oscillation in the South American sector. Part I: surface climate. Monthly Weekly Review, v.116, p.505-524, 1988.

ALLEN, R.G.; PEREIRA, L.S.; RAES, D.; SMITH, M. Crop evapotranspiration: guidelines for computing crop water requirements. Rome: FAO, 1998. 300p. (FAO Irrigation and Drainage Paper, 56).

ANDRADE, F.H.; CIRILO, A.; UHART, S.; OTEGUI, M. Ecofisiología del cultivo de maíz. Buenos Aires: La Barrosa Ed., 1996. 291p.

ANDRADE, F.H.; VEGA, C.; UHART, S.; CIRILO, A.; CANTARERO, A.; VALENTINUZ, O. Kernel number determination in maize. Crop Science, v.39, p.453-459, 1999.

BAETHGEN, W. Uso de modelos de simulación en manejo y fertilidad de suelos. In. II Curso de actualización técnica manejo y fertilidad de suelos. INIA La Estanzuela. Uruguay. 1995.

BAKER, J.T.; PINTER, P.J.; REGINATO, R.J.; KANEMASU, E.T. Effect of temperature on leaf appearance in spring and winter wheat cultivars. Agronomy Journal, v.78, p.605-613, 1986. 
BANNAYAN, M.; CROUT, N.M.J.; HOOGENBOOM, G. Application of the CERESWheat model for within season prediction of winter wheat yield in the United Kingdom. Agronomy Journal, v. 95, p.114-125, 2003.

BARBANO T.M.; DUARTE P.A.; BRUNINI, O.; RECO P.C.; PATERNIANI, M.E.A.G.; KANTHACKL, R.A.D. Base temperature and accumulated heat units for the sub-period sowing-flowering phase for maize cultivars in São Paulo State. Revista Brasileira de Agrometeorologia, v.9, p.261-268, 2001.

BAUER, A.; FRANK, A.B.; BLACK, A.L. Estimation of spring wheat leaf growth rates and anthesis from air temperature. Agronomy Journal, v.76, p.829-835, 1984.

BEN NOUNA, B.; KATERJI, N.; MASTRORILLI, M. Using the CERES-Maize model in a semi-arid Mediterranean environment. New modelling of leaf area and water stress functions. European Journal of Agronomy, v.19, p.115-123, 2003.

BIRCH, C.J.; HAMMER, G.L.; RICKERT, K.G. Temperature and photoperiod sensitivity of development in five cultivars of maize (Zea Mays L.) from emergence to tassel initiation. Field Crop Research, v.55, p. 93-107, 1998a.

BIRCH, C.J.; VOS, J.; KINIRY, J.; BOS, H.J.; ELINGS, A. Phyllochron responds to acclimation to temperature and irradiance in maize. Field Crops Research, v.59, p.187-200, 1998b.

BIRCH, C.J.; VOS, J.; VAN DER PUTTEN, P.E.L. Plant development and leaf area production in contrasting cultivars of maize grown in a cool temperate environment in the field. European Journal of Agronomy, v.19, p.173-188, 2003.

BOLAÑOS J., EDMEADES G.O. The importance of the anthesis-silking interval in breeding for drought tolerance in tropical maize. Field Crops Research, v.48, p.6580, 1996.

BONHOMME, R. Bases and limits to using 'degree-day' units. European Journal of Agronomy, v.13, p.1-10, 2000. 
BOOGES, W.G.; RITCHIE, J.T. Economic and risk analysis of irrigation decisions in humid regions. Journal Production Agricultural, v.1, n.2, p.116-122, 1998.

BOOTE, K.J; JONES, J.W.; PICKERING, N.B. Potential uses and limitations of crops models. Agronomy Journal, v. 88, p.704-716, 1996.

BOULLON, D.R; RODRÍGUEZ, G.R.; MAGRÍN G.O. Aplicación de CERES-Maize a la estimación de rendimientos regionales. In: REUNIÓN ARGENTINA DE FISIOLOGÍA VEGETAL, 21., Argentina, 1996. Actas. Argentina: INTA Castelar, 1996. p.168-170.

BOWEN, W.T.; JONES, J.W; CARSKY, R.J; QUINTANA, J.O. Evaluation of the nitrogen sub-model of CERES-Maize following legume green manure incorporation. Agronomy Journal, v.85, p.153-159, 1993.

BROOKING, I.R.; MCPHERSON, H.G. The impact of weather on the scheduling of sweet corn for processing: Quantifying the link between rate of development and the environment. Crop Horticultural Science, v.17, p.19-26, 1989.

CANTARELlA, H. Adubação do milho "safrinha". In: SEMINÁRIO SOBRE A CULTURA DO MILHO "SAFRINHA", 5., Barretos, 1999. Anais. Barretos: CATI, IAC, IEA, 1999. p.15-19.

CARAMORI, P.H.; WREGE, M.S.; GONÇALVES, S. L. Zoneamento da cultura de milho "safrinha" e épocas de semeadura no estado de Paraná. In: SEMINÁRIO SOBRE A CULTURA DO MILHO "SAFRINHA", 5., Barretos, 1999. Anais. Barretos: CATI; IAC; IEA, 1999. p.19-24.

CARDOSO, C.O. Análise de riscos climáticos e estratégias de irrigação para milho "safrinha" no Paraná, através de modelos de simulação. Piracicaba, 2001. 114p. Tese (Doutorado) - Escola Superior de Agricultura Luiz de Queiroz, Universidade de São Paulo.

CASTELÁN-ORTEGA, O.A; FAWCETT, R.H; ARRIAGA-JORDAN, C; HERRERO, M. A decision support system for small holder campesino maize-cattle production systems of the Toluca Valley in Central Mexico. Part I - Integrating biological and 
socio-economic models into holistic system. Agricultural Systems, v. 75, p.1-21, 2003.

CAVERO, J.; FARRE. I.; DEBAEKE, P.; FACI, J.M. Simulation of maize yield under water stress with the EPIC phase and CROPWAT models. Agronomy Journal, v.92, p.679-690, 2000.

CENTER FOR OCEAN-ATMOSPHERIC PREDICTION STUDIES. ENSO index according to JMA SSTA. http://www.coaps.fsu.edu/research/jma index1.shtml (3 de maio de 2004).

COSTA, L.C. Modelagem e simulação em agrometeorologia. In: CONGRESSO BRASILEIRO DE AGROMETEOROLOGIA, 10., Piracicaba, 1997. Suplemento dos anais. Piracicaba: SBA, 1997. p.3-6.

CROSS, H.Z.; ZUBER, M.S. Prediction of flowering dates in maize based on different methods of estimating thermal units. Agronomy Journal, v.64, p.351-355, 1972.

CUTFORTH, H.W.; JAME, Y.W.; JEFFERSON, P.G. Effect of temperature, vernalization and water stress on phyllochron and final main-stem leaf number of HY320 and Neepawa spring wheats. Canadian Journal of Plant Science, v.72, p.1141-1151, 1992.

CHASE, S.S.; NANDA, D.K. Number of leaves and maturity classification in Zea Mays L. Crop Science, v.7, p.431-432, 1967.

CHIPANSHI, A. C.; RIPLEY, E.A.; LAWFORD, R.G. Early prediction of spring wheat yields in Saskatchewan form current and historical weather data using the CERESWheat model. Agricultural and Forest Meteorology, v. 84, p.223-232, 1997.

CHIPANSHI, A.C.; RIPLEY, E.A.; LAWFORD, R.G. Large-scale simulation of wheat yields in a semi-arid environment using a crop-growth model. Agricultural Systems, v.59, p57-66, 1999. 
DE WIT, C.T. Simulation of living systems. In: PENNING DE VRIES, F.W.T.; VAN LAAR, H.H. (Ed.) Simulation of plant growth and crop production. Wageningen: Pudoc, 1982. p.3-8.

DOURADO-NETO, D.; NIELSEN, D.R.; HOPMANS, J.W.; REICHARDT, K.; SANTOS BACCHI, O.O.; LOPES, P.P. Soil water retention curve (software): version 3.0. Piracicaba: ESALQ, 2001.

DUARTE，A.P.; ALLIPRANDINI， L.F; SAWAZAKI， E.; KANTHACK，R.A.D. Avaliação de cultivares de milho "safrinha" no vale Paranapanema. In: CONGRESSO NACIONAL DE MILHO E SORGO, 20., Goiânia, 1994. Goiânia:. ABMS; EMGOPA; EMBRAPA, CNPMS; UFG; EMATER-GO, 1994. p.91-94.

DUCHON, C.E. Corn yield prediction using climatology. Journal of Climate and Applied Meteorology, v. 25, n.5, p.581-585, 1986.

DWYER, L. M.; STEWART, B.L.; CARRIGAN, L. Performance of a revised thermal index. Canadian Journal of Soil Science, v.76, p.559. 1996.

DWYER, L.M.; STEWART, D.W.; CARRIGAN, L.; MA, B.L.; NEAVE, P.; BALCHIN, D. A general thermal index for maize. Agronomy Journal, v.91, p.940946, 1999.

ECK, H.V. Irrigated corn yield response to nitrogen and water. Agronomy Journal, v.76, p.421-428, 1984.

ELLIS， R.H.; SUMMERFIELD, R.J.; EDMEADES, G.O.; ROBERTS， E.H. Photoperiod, leaf number, and interval from tassel initiation to emergence in diverse cultivars of maize. Crop Science, v.32, p.398-403, 1992.

ESTEVES, A.; PEREIRA, EBC; RUSCHEL, R. Avaliação de características agronômicas em cultivares de milho (Zea Mays) introduzidas, no plantio de "safrinha". In: CONGRESSO NACIONAL DE MILHO E SORGO, 20., Goiânia, 1994. Centro-Oeste: cinturão de milho e sorgo no Brasil; resumos. Goiânia: ABMS,EMGOPA,EMBRAPA, CNPMS,UFG, EMATER-GO, 1994. p.36. 
FANCELLI, A.L.; DOURADO-NETO, D. Ecofisiologia e Fenologia. In: GUAÍBA AGROPECUÁRIA (Ed.). Produção de milho. 2000. pp.21-54.

FAPOHUNDA, H.O.; HUSSAIN, M.M. Water and fertilizer interrelations with irrigated corn. Agricultural and Water Management, v.18, p.49-61, 1990.

FARIA, R.T. DE; FOLEGATTI, M.V; FRIZZONE, J.A; SAAD, A.M. Determination of a long-term optimal irrigation strategy for dry beans in Parana State, Brazil. Scientia Agrícola, v. 54, número especial, p.155-164. 1997.

FISCHER K.S.; EDMEADES G.O.; JOHNSON E.C. Selection for the improvement of maize yield under moisture-deficits. Field Crops Research, v. 22, p.227-243, 1989.

FONTANA, D.C.; WEBER, E.; DUCATI, J.; FIGUEIREDO, D.C.; BERLATO, M.A.; BERGAMASCHI, H. Monitoramento e previsão de safras no Brasil. In: LATIN AMERICAN SYMPOSIUM ON REMOTE SENSING, 9., Puerto Iguazú, 2000. Argentina: SELPER, 2000. p.1-11.

FREESE, F. Elementary statistical methods for foresters. U.S. DEPARTMENT OF AGRICULTURE (Ed). Forest Service. Agricultural Handbook No. 317. 1967. 87p.

FREY, N.M. Dry matter accumulation in kernels of maize. Crop Science, v.21, p.118$122,1982$.

FRIEND, D.J.C.; HELSON, V.A.; FISHER, J.E. Changes in the leaf area ratio during growth of Marquis wheat, as affected by temperature and light intensity. Canadian Journal of Botany, v.43, p.15-28, 1965.

GARCIA, A.G.Y.; HOOGENBOOM, G.; SOLER, C.M.T.; STOOKBURY, D.E. The impact of climate variability on peanut yield forecast in Georgia. In: ANNUAL MEETINGS 2003. Abstracts [CD-ROM]. ASA, CSSA, and SSSA, Madison, WI. 2003.

GEDANKEN, A. Utilização do modelo Ceres-Maize na avaliação de estratégias de irrigação na cultura do milho em duas regiões de Minas Gerais. Viçosa, 1998. 74p. Dissertação (Mestrado) - Universidade Federal de Viçosa. 
GIJSMAN, A.J.; HOOGENBOOM, G.; PARTON, W.J.; KERRIDGE, P. C. Modifying DSSAT crop models for low input agricultural systems using a soil organic matter residue module form CENTURY. Agronomy Journal, v.94, p.462-474, 2002.

GOMES, L. Satélites ajudarão a prever safra agrícola. Reportagens. http://www.pnud.org.br/index.php?lay=news\&id01=347\&are=mam $(20$ de maio de 2004).

GRANT, R.F.; JACKSON, B.S.; KINIRY, J.R.; ARKIN, G.F. Water deficit timing effects on yield components in maize. Agronomy Journal, v.81, p.61-65, 1989.

GREENWOD, E.A.N. Nitrogen stress in plants. Advances in Agronomy, v.28, p.1-35, 1976.

GRIMM, A.; TELEGINSKY, S.E.; FREITAS, E.E.D COSTA, S. M. S.; FERLIZI, P. G.; GOMES, J. Anomalias de precipitação no sul do Brasil em eventos de "El Niño". In: CONGRESSO BRASILEIRO DE METEOROLOGIA, 9. Anais. Campos de Jordão. Sociedade Brasileira de Meteorologia, 1996. p. 1098-1102.

GRIMM, A.M.; BARROS, V.R.; DOYLE, M.E. Climate variability in southern South America associated with El Niño and La Niña events. Journal of Climate, v.13, p.35-58, 2000.

GUNGULA, D.T.; KLING, J.G.; TOGUN, A.O. CERES-Maize predictions of maize phenology under nitrogen-stressed conditions in Nigeria. Agronomy Journal, v.95, p.892-899, 2003.

HALL, A.J.; LEMCOFF, J.H.; TRAPANI, N. Water stress before and during flowering in maize and its effects on yield, its components, and their determinants. Maydica, v.26, p.19-38, 1981.

HARDER, D.; CARLSON, R.E.; SHAW, R.H. Yield and yield components and nutrient content of corn grain as influenced by post-silking moisture stress. Agronomy Journal, v.174, p.275-278, 1982. 
HAY, R.K.M.; GILBERT, R.A. Variation in the harvest index of tropical maize: evaluation of recent evidence from Mexico and Malawi. Annals of Applied Biology, v.138, p.103-109, 2001.

HEINEMANN, A.B. Manejo de irrigação utilizando modelos de simulação de crescimento de culturas CROPGRO e CERES. Piracicaba, 2001. 67p. Tese (Doutorado) - Escola Superior de Agricultura Luiz de Queiroz, Universidade de São Paulo.

HODGES, T.; EVANS, D.W. Leaf emergence and leaf duration related to thermal time calculations in CERES-Maize. Agronomy Journal, v.84, p.724-730 , 1992.

HOOGENBOOM, G. Contribution of agrometeorology to the simulation of crop production and its applications. Agricultural and Forest Meteorology, v.103, p. 137-157. 2000.

HOOGENBOOM, G. Crop Growth and development. In: BENBI, D.K; NIEDER, R. (Ed.). Handbook of processes and modeling in the soil-plant system. New York: Food Product Press and The Haworth Press, 2003. p.655-691.

HOOGENBOOM, G.; JONES, J.W.; BOOTE, K.J. Modeling growth, development, and yield of grain legumes using SOYGRO, PNUTGRO, and BEANGRO: a review. Transaction of the ASAE, v.35, p.2043-2055, 1992.

HOOGENBOOM, G.; JONES, J.W.; WILKENS, P.W.; BATCHELOR, W.D.; BOWEN, W.T.; HUNT, L.A.; PICKERING, N.B.; SINGH, U.; GODWING, D.C.; BAER, B.; BOOTE, K.J.; RITCHIE, J.T.; WHITE, J.W. Crops models. In: TSUJI, G.Y.; UEHARA, G.; BALAS, S. (Ed.). DSSAT v3, decision support system for agrotechnology transfer. Honolulu: University of Hawai, 1994. v.2, cap.2, p.95244.

HOOGENBOOM, G.; JONES, J.W.; WILKENS, P.W.; PORTER, C.H.; BATCHELOR, W.D.; HUNT, L.A.; BOOTE, K.J.; SINGH, U.; URYASEVA, O.; BOWEN, W.T.; GIJSMAN, A.J.; DU TOIT, A.S.; WHITE J.W.; TSUJI, G.Y. Decision support 
system for agrotechnology transfer: version 4.0 (compact disc). Honolulu: University of Hawaii, 2003.

HOOGENBOOM, G; WHITE, J.W. Improving physiological assumptions of simulation models by using gene-based approaches. Agronomy Journal, v. 85, p.82-89. 2003.

HOTSONYAME, G.K.; HUNT, L.A. Sowing date and photoperiod effects on leaf appearance in field grown wheat. Canadian Journal of Plant Science, v.77, p.2331, 1997.

HOWELL, T.A.; TOLK, J.A.; SCHNEIDER, A.D.; EVETT, S.R. Evapotranspiration, yield, and water use efficiency of corn hybrids differing in maturity. Agronomy Journal, v.90, p.3-9, 1998.

HOWELL, T.A.; YAZAR, A.; SCHNEIDER, A.D.; DUSEK, D.A; COPELAND, K.S. Yield and water use efficiency of corn in response to LEPA irrigation. Transactions of the ASAE, v.38, p.1737-1747, 1995.

HUNT, L.A.; PARAJASINGHAM, S.; JONES, J. W.; HOOGENBOOM, G.; IMAMURA, D. T.; OGOSHI R. M. Gencalc: software to facilitate the use of crop models for analyzing field experiments. Agronomy Journal, v.85, p.1090-1094, 1993.

HUNT, L.A.; REYNOLDS, M.P; SAYRE, K.D; RAJARAM, S; WHITE, J.W.; YAN, W. Crop modeling and the identification of stable coefficients that may reflect significant groups of genes. Agronomy Journal, v.95, p.20-31. 2003.

HUNT, L.A.; WHITE, J.W.; HOOGENBOOM, G. Agronomic data: advances in documentation and protocols for exchange and use. Agricultural Systems, v.70, p.477-492. 2001.

IEA. Instituto de Economia Agrícola. 2003. http://www.iea.sp.gov.br/out/ibcoiea.htm (5 de maio de 2003).

IRAGAVARAPU, R. Basing hybrid maturity switches on long-term data. 1999. Crop Insights 9. http://www.pioneer.com/usa/agronomy/corn/1012.htm (abril 2004). 
JAME, Y. W.; CURTFORTH, H.W. Crop growth models for decision support systems. Canadian Journal of Plant Science, v. 76, p.9-19, 1996.

JAME, Y.W.; CUTFORTH, H.W.; RITCHIE, J.T. Temperature response function for leaf appearance rate in wheat and corn. Canadian Journal of Plant Science, v.79, p.1-10, 1999.

JAMIESON, P.D.; PORTER, J.R.; WILSON, D.R. A test of the computer simulation model ARC-WHEAT1 on wheat crops grown in New Zeland. Field Crops Research, v.27, p.337-350. 1991.

JONES, J.W. Decision support systems for agricultural development. In: PENNING DE VRIES F.W.T, TENG PS, METSELAAR K (Ed.) Systems approaches for agricultural development. Boston: Kluwer Academic Press, 1993. p.459-471.

JONES, J.W.; HOOGENBOOM, G.; PORTER, C.H.; BOOTE, K.J.; BATCHELOR, W.D.; HUNT, L.A.; WILKENS, P.W.; SINGH, U.; GIJSMAN, A.J.; RITCHIE, J.T. DSSAT Cropping system model. European Journal of Agronomy, v.18, p.235265, 2003.

JONES, J.W.; KINIRY, J.R. CERES-Maize: a simulation model of maize growth and development. College Station: Texas A\&M Univ. Press, 1986. 194p.

JONES, J.W.; MISHOE, J.W.; BOOTE, K.J. Introduction to simulation and modeling. Florida; ASPAC-Food and Fertilizer Technology Center. Technical Bulletin, v.100, 19p. 1987.

JONES, J; TSUJI, G; HOOGENBOOM, G; HUNT, L; THORNTON, P; WILKENS, P; IMAMURA, D; BOWEN, W; SINGH, U. Decision support system for agrotechnology transfer: DSSAT v.3. In: TSUJI, G; HOOGENBOOM, G.; THORNTON, P. (Ed.) International benchmark sites network for agrotechnology transfer: a system approach to research and decision making. Kluwer Academic Press, 1996. 
KAMARA, A.Y.; MENKIR, A.; BADU-APRAKU, B.; IBIKUNLE, O. The influence of drought stress on growth, yield and yield components of selected maize genotypes. Journal of Agricultural Science, v.141, p.43-50, 2003.

KARAM, F.; BREIDY, J.; STEPHAN, C.; ROUPHAEL, J. Evapotranspiration, yield and water use efficiency of drip irrigated corn in the Bekaa Valley of Lebanon. Agricultural and Water Management, v.63, p.125-137, 2003.

KIM, S.H.; REDDY, V.R.; TIMLIN, D.J. Modeling maize phenology as a function of temperature and photoperiod using nonlinear rate equations. In: 2004 BIOLOGICAL SYSTEMS SIMULATION GROUP ANNUAL MEETINGS, 2004, Gainesville, FL. Abstracts of the 2004 BSSG Annual Meeting, p.45. University of Florida, IFAS. 2004.

KINIRY, J.R. Maize Phasic Development. In: HANKS, J.; RITCHIE, J.T. (Ed.) Modeling Plant and Soil Systems. Madison, Wisconsin: ASA, 31, 1991. cap.4, p.55-70.

KINIRY, J.R.; BONHOMME, R. Predicting maize phenology, In: HODGES, T. (Ed.). Predicting crop phenology. Boca Raton: CRC Press, 1991. cap.11, p.115-131.

KINIRY, J.R.; RITCHIE, J.T. Shade-sensitive interval of kernel number of maize. Agronomy Journal, v.77, p.711-715, 1985.

LANDERS, J.N. Fascículo de experiências de plantio direto no cerrado. Goiânia. 1994. $261 \mathrm{p}$.

LECAIN, D.R.; AIGUO, L.; MORGAN, J.A.; MCMASTER, G.S.; HENDRIX, D.L. Long and short term acclimation of spring wheat to ambient and elevated $\mathrm{CO} 2$ : gas exchange and development. In: ANNUAL MEETINGS 1992. Abstracts. Abst. 127. ASA, CSSA, and SSSA, Minneapolis, MN. 1992.

LEMOS, M.C.; FINAN, T.J.; FOX, R.W.; NELSON, D.R; TUCKER, J. The use of seasonal climate forecasting in policymaking: lessons from Northeast Brazil. Climatic Change, v.55, p.479-507, 2002. 
LIMA, M.G. Calibração e validação do modelo CERES-Maize em condições tropicais do Brasil. Piracicaba, 1995. 119p. Tese (Doutorado) - Escola Superior de Agricultura Luiz de Queiroz, Universidade de São Paulo.

LIU, W.T.H; BOTNER, D.M.; SAKAMOTO, C.M. Aplication of CERES-Maize model to yield prediction of a Brazilian maize hybrid. Agricultural and Forest Meteorology. v. 45, p.299-312, 1989.

LOAGUE, K.; GREEN, R.E. Statistical and graphical methods for evaluating solute transport models: overview and application. Journal of Contaminant Hydrology, v.7, p.51-73, 1991.

LONGNECKER, N.; KIRBY, E.J.M.; ROBSON, A. Leaf emergence, tiller growth, and apical development of nitrogen-deficient spring wheat. Crop Science, v.33, p.154$160,1993$.

MARENGO, J. Interannual variability of surface climate in the Amazon basin. International Journal of Climatology, v.12, p.853-863, 1992.

MASS, E.V.; GRIEVE, C.M. Spike and leaf development in salt stressed wheat. Crop Science, v.30, p.1309-1313, 1990.

MAVROMATIS, T.; BOOTE, K.J.; JONES, J.W.; WILKERSON, G.G. and HOOGENBOOM, G. Repeatability of model genetic coefficients derived from Soybean performance trials across different states. Crop Science, v.42, p.76-89. 2002 .

McKEE, G.W. A Coefficient for computing leaf area in hibrid corn. Agronomy Journal, v.56, p.240-241, 1964.

McMASTER, G.S.; WILHELM, W.W. Comparison of the equations for predicting the phyllochron of wheat. Crop Science, v.35, p.30-36, 1995.

McMASTER, G.S.; WILHELM, W.W. Growing degree-days: one equation, two interpretations. Agricultural and Forest Meteorology, v.87, p.291-300, 1997. 
MISHRA, H.S.; RATHORE, T.R.; SAVITA, U.S. Water-use efficiency of irrigated winter maize under cool weather conditions of India. Irrigation Science, v.21, p.2733, 2001.

MONTEITH, J. The quest balance in crop modeling. Agronomy Journal, v.88, p.695697, 1996.

MUCHOW, R.C.; HAMMER, G.L.; CARBERRY, P.S. Optimizing crop and cultivar selection in response to climatic risk. In: MUCHOW, R.C.; BELLAMY, J.A. (Ed.). Climatic risk in crop production: models and management for the semiarid tropics and subtropics. Wallingford: CAB International, 1991. p.235-262.

MUCHOW, R.C.; SINCLAIR, T.R.; BENNETT, J.M. Temperature and solar radiation effects on potencial maize yield across locations. Agronomy Journal, v.82, p.338$343,1990$.

MUCHOW, R.C; CARBERRY, P.S. Environmental control of phenology and leaf growth in a tropically adapted maize. Field Crops Research, v.20, p.221-236, 1989.

MUSICK, J.T.; DUSEK, D.A. Irrigated corn yield response to water. Transactions of the ASAE, v.23, p.92-103, 1980.

NESMITH, D.S.; RITCHIE, J.T. Short and long-term response of corn genotypes in the field. Agronomy Journal, v.78, p.699-703, 1992a.

NESMITH D.S.; RICTHIE, J.T. Short and long term responses of corn to a pre-anthesis soil water deficit. Agronomy Journal, v.84, p.107-113, $1992 \mathrm{~b}$.

NIJBROEK, R.; HOOGENBOOM, G.; JONES, J.W. Optimizing irrigation management for a spatially variable soybean field. Agricultural Systems, v.76, p.353-377, 2003.

NOVOA, R.; LOOMIS, R.S. Nitrogen and plant production. Plant Soil, v.58, p.177-204, 1981.

OLIVEIRA, M.D.X. DE; ANDRADE, J.A.C.; ARF,O. e PASTANA, A.K.M.P. Estudo de épocas de semeadura e ciclo de cultivar de milho "safrinha" na região sudeste do Mato Grosso do Sul. In: CONGRESSO NACIONAL DE MILHO E SORGO, 20., 
Goiânia, 1994. Centro-Oeste: cinturão de milho e sorgo no Brasil; resumos. Goiânia, ABMS/EMGOPA/EMBRAPA, CNPMS/UFG/EMATER-GO, 1994. p. 177.

OLIVEIRA, M.D.X. de; FORNASIERI, D. Época de semeadura de milho "safrinha" para a região centro-norte do estado de Mato Grosso do Sul. In: SEMINÁRIO SOBRE A CULTURA DO MILHO "SAFRINHA", 5., Barretos, 1999. Anais. Barretos: CATI; IAC; IEA, 1999. p.77-86.

OTEGUI, M.E. Kernel set and flower synchrony within the ear of maize: II. Plant population effects. Crop Science, v.37, p.448-455, 1997.

PANDEY, R.K.; MARANVILLE, J.W.; ADMOU, A. Deficit irrigation and nitrogen effects on maize in a Sahelian environment I. grain yield and yield components. Agricultural and Water Management, v.46, p.1-13, 2000.

PANDEY, R.K.; MARANVILLE, J.W.; CHETIMA, M.M. Deficit irrigation and nitrogen effects on maize in a Sahelian environment II. Shoot growth, nitrogen uptake and water extraction. Agricultural and Water Management, v.46, p.15-27, 2001.

PETERSON, C.M.; KLEPPER, B.; RICKMAN, R.W. Seed reserves and seedling development in winter wheat. Agronomy Journal, v.81, p.245-251, 1989.

PLETT, S. Comparison of seasonal thermal indices for measurement of corn maturity in a prairie environment. Canadian Journal of Plant Science, v.72, p.1157-1162, 1992.

QUIESSI, J.A.; DUARTE, A.P.; BICUDO, S.J.; ZAGATTO, M.E.A.G. Rendimento de grãos e características fenológicas do milho em diferentes épocas de semeadura, em Tarumã (SP). In: SEMINÁRIO SOBRE A CULTURA DO MILHO "SAFRINHA", 5., Barretos, 1999. Anais. Barretos: CATI; IAC; IEA, 1999. p.239-248.

RICKMAN R.W.; KLEPPER, B.L. The phyllochron: where do we go in the future? Crop Science, v.35, p.44-49, 1995. 
RINALDI, M. Application of EPIC model for irrigation scheduling of sunflower in Southern Italy. Agricultural and Water Management, v.49, p.185-196, 2001.

RITCHIE, J.T. Soil water balance and plant water stress. In: TSUJI, G.Y.; HOOGENBOOM, G.; THORNTON, P.K. (Ed.). Understanding options for agricultural production. Dordrecht: Kluver Academic, 1998. p.41-54.

RITCHIE, J.T; SINGH, U.; GODWIN, D.C; BOWEN, W.T. Cereal growth, development and yield. In: TSUJI, G.Y.; HOOGENBOOM, G.; THORNTON, P.K. (Ed.). Understanding options for agricultural production. Dordrecht: Kluver Academic, 1998. p.79-98.

ROPELEWISKY, C.F.; JONES, P.D. An extension of the Tahiti-Darwin southerns oscillation index. Monthly Weekly Review, v.115, p.2161-2165, 1987.

ROPELEWSKI, C.; HALPERT, M. Global and regional scale precipitation patterns associated with the high index phase of the Southern Oscillation. Journal of Climate, v.2, p.268-284, 1989.

ROTH, G.W.; YOCUM, J.O. Use of hybrid growing degree day ratings for corn in the northeastern USA. Journal of Production Agriculture, v.10, p.283-288, 1997.

SALVADOR, R. J. Use of Computerized Simulation to Advance Agricultural Research in Developing Countries. Eighth International Congress on Research in Electrical Sciences. Instituto Tecnológico de la Laguna, 20 - 24 September 1993, Torreón, Coahuila, México. 1993.

SAS INSTITUTE. SAS system. 8.ed. Cary, 2001.

SHAYKEWICH, C.F. An appraisal of cereal crop phenology modeling. Canadian Journal of Plant Science, v.75, p.329-341, 1995.

SOLER, C.M.T., FOLEGATTI, M.V; FARIA, R.T. Uso do modelo CERES-Maize para identificação de características genéticas desejáveis e de práticas adequadas de manejo em milho "safrinha". Revista Brasileira de Agrometereologia, v.9, n.2, p.339-346, 2001. 
STEWART, D.W.; DWYER, L.M.; CARRIGAN, B.L. Phenological temperature response of maize. Agronomy Journal, v.90, p.73-79, 1998.

THOMPSON, L.M. Climatic change, weather variability, and corn production. Agronomy Journal, v.78, p.649-653, 1986.

THORNTON, P.K.; BOWEN, W. T.; RAVELO, A. C.; WILKENS, P. W.; FARMER, G.; BROCK, J.; BRINK, J. E. Estimating millet production for famine early warning: an application of crop simulation modeling using satellite and groundbased data in Burkina Faso. Agricultural and Forest Meteorology, v.83, p.95-112, 1997.

THORNTON, P.K.; HOOGENBOOM, G.; WILKENS, P.W.; BOWEN, W.T. A computer program to analyze multiple-season crop model outputs. Agronomy Journal, v.87, p.131-136. 1995.

THORNTON, P.K.; SAKA, A.R; SING, U; KUMWENDA, J.D.T; BRINK, J.E; DENT, J.B. Application of a maize crop simulation model in the central region of Malawi. Experimental Agriculture, v. 31, n.2, p.213-226, 1995.

TOLK, J.A.; HOWELL, T.A.; EVETT, S.R. Evapotranspiration and yield of corn grown on three high plains soils. Agronomy Journal, v.90, p.447-454, 1998.

TOLLENAAR, M. Duration of the grain-filling period in maize is not affected by photoperiod and incident PPFD during the vegetative phase. Field Crops Research, v.62, p.15-21, 1999.

TOLLENAAR, M. The influence of developmental patterns on grain yield of maize. In: INTERNATIONAL CONGRESS OF PLANT PHYSIOLOGY, New Delhi, 1988. Proceedings. India: SINHA, S.K., SANE, P.V., BHARGAVA, S.C., AND AGRAWAL, P.K., (Eds.). 1988. p.181-193.

TOLLENAAR, M.; HUNTER, R.B. A photoperiod and temperature sensitive period for leaf number in maize. Crop Science, v.23, p.457-460, 1983. 
TSUJI, G.Y.; JONES, J.W.; HOOGENBOOM, G.; HUNT, L.A.; THORNTON, P.K. Introduction. In: TSUJI, G.Y.; UEHARA, G.; BALAS, S (Ed.). DSSAT v3, Decision support system for agrotechnology transfer. Honolulu: University of Hawaii, 1994. v.1, cap.1, p.1-4.

TSUNECHIRO, A. Análise do risco da produção e do mercado de milho "safrinha" In: SEMINÁRIO SOBRE A CULTURA DO MILHO "SAFRINHA", 5., Barretos, 1999. Anais. Barretos: CATI/IAC/IEA, 1999. p.127-132.

TSUNECHIRO, A. Milho. In: Prognostico Agrícola. São Paulo: APTA, v.2, p.233-240. 2002.

TYAGI, N.K.; SHARMA, D.K.; LUTHRA, S.K. Determination of evapotranspiration for maize and berseem clover. Irrigation Science, v.21, p.173-181, 2003.

UEHARA, G \& TSUJI, G. The IBSNAT project. In: PENNING DE VRIES F.W.T, TENG PS, METSELAAR K (Ed.) Systems approaches for agricultural development. Kluwer Academic Press, Boston. 505-513. 1993.

UHART, S.A.; ANDRADE, F.H. Nitrogen deficiency maize. II. Carbon-nitrogen interaction on kernel number and grain yield. Crop Science, v.35, p.1384-1389, 1995.

UVO, C. Influence of sea surface temperature on rainfall and runoff in northeastern South America: analysis and modelling. Lund, 1998. 120p. Dissertation (M.S.) Lund University.

VAN GENUCHTEN, M. A closed form equation for predicting hydraulic conductivity in unsaturated soils. Soil Science Society of America Journal, v. 44, p.892-898, 1980.

WARRINGTON, I.J.; KANEMASU, E.T. Corn growth response to temperature and photoperiod. I. Seedling emergence, tassel initiation and anthesis. Agronomy Journal, v.75, p.749-754, 1983. 
WHITE, J.W; HOOGENBOOM, G. Gene-based approaches to crop simulation: past experiences and future opportunities. Agronomy Journal, v.95, p.52-64, 2003.

WILKENS, P.W.; BATCHELOR, W.D.; BOOTE, K.J.; GIJSMAN, A.J.; HUNT, L.A.; JONES, J.W.; PORTER, C.H.; SINGH, U; DU TOIT, A.S; TSUJI, G.Y.; URYASEVA, O; HOOGENBOOM, G. 2003. Decision Support System for Agrotechnology Transfer Version 4.0. Annual Meetings Abstracts (CD-ROM). American Society of Agronomy, Madison, WI.

WILLMOTT, C.J.; AKLESON, G.S.; DAVIS, R.E.; FEDDEMA, J.J.; KLINK, K.M.; LEGATES, D.R.; ODONNELL, J.; ROWE, C.M. Statistics for the evaluation and comparison of models. Journal of Geophysical Research, v.90, p.8995-9005, 1985.

YIN, X.; KROPFF, M.J.; MCLAREN, G.; VISPERAS, R.M. A non linear model for crop development as a function of temperature. Agricultural and Forest Meteorology, v.77, p.1-16, 1995. 